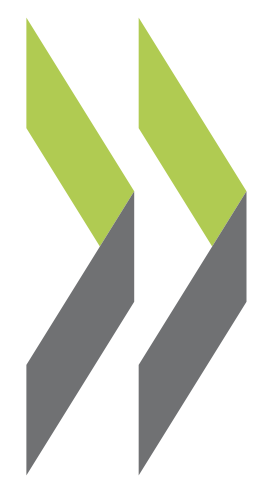

OECD Economics Department Working Papers No. 926

\title{
Less Income Inequality and More Growth - Are They Compatible? Part 3. Income Redistribution via Taxes and Transfers Across OECD Countries
}

Isabelle Joumard, Mauro Pisu, Debra Bloch 
Organisation de Coopération et de Développement Économiques

Organisation for Economic Co-operation and Development

10-Jan-2012

ECONOMICS DEPARTMENT

English - Or. English

LESS INCOME INEQUALITY AND MORE GROWTH - ARE THEY COMPATIBLE?

PART 3. INCOME REDISTRIBUTION VIA TAXES AND TRANSFERS ACROSS OECD COUNTRIES

ECONOMICS DEPARTMENT WORKING PAPER No. 926

by Isabelle Joumard, Mauro Pisu and Debbie Bloch

All Economics Department Working Papers are available through OECD's internet website at www.oecd.org/eco/workingpapers 


\section{ABSTRACT/RESUME \\ Less income inequality and more growth - Are they compatible? Part 3. Income redistribution via taxes and transfers across OECD countries}

Taxes and transfers reduce inequality in disposable income relative to market income. The effect varies, however, across OECD countries. The redistributive impact of taxes and transfers depends on the size, mix and the progressivity of each component. Some countries with a relatively small tax and welfare system (e.g. Australia) achieve the same redistributive impact as countries characterised by much higher taxes and transfers (e.g. Germany) because they rely more on income taxes, which are more progressive than other taxes, and on means-tested cash transfers. This paper provides an assessment of the redistributive effect of the main taxes and cash transfers based on a set of policy indicators and a literature review. It also identifies empirically four groups of countries with tax and transfer systems that share broadly similar features. The paper then assesses potential trade-offs and complementarities between economic growth and income redistribution objectives associated with various tax and transfer reform options.

JEL classification codes: $\mathrm{H} 2 ; \mathrm{H} 23 ; \mathrm{H} 53 ; \mathrm{I} 3 ; \mathrm{I} 38$

Keywords: Income inequality; taxes; transfers; welfare systems; redistribution; progressivity; cluster analysis

$$
\text { +++++++++++++++++++ }
$$

\section{Moins d'inégalités de revenu et plus de croissance - Ces deux objectifs sont-ils compatibles ? Partie 3. Redistribution du revenu par le biais de l'impôt et des transferts dans les pays de l'OCDE}

Les impôts et les transferts amènent les inégalités de revenu disponible à un niveau inférieur à celles du revenu marchand. Cet effet redistributif des impôts et transferts n'a pas la même ampleur dans tous les pays de l'OCDE. Il dépend de la taille, de la composition des impôts et transferts ainsi que de la progressivité de chaque composante. Certains pays ayant un système fiscal et de protection sociale relativement peu importants (comme l'Australie, par exemple) obtiennent le même effet redistributif que des pays où les impôts et les transferts sont beaucoup plus élevés (comme l'Allemagne) du fait qu'ils recourent davantage aux impôts sur le revenu, plus progressifs que les autres impôts, et à des transferts en espèces ciblés sur les ménages les plus démunis. Ce document donne une évaluation de l'effet redistributif des principaux impôts et transferts à partir d'une série d'indicateurs de l'action publique et d'une revue des études existantes. Il identifie aussi, de manière empirique, quatre groupes de pays dont les systèmes fiscaux et de protection sociale présentent des caractéristiques à peu près similaires. Le document évalue ensuite les arbitrages et complémentarités potentiels entre les objectifs de croissance économique et de redistribution du revenu relatifs aux diverses possibilités de réforme des systèmes fiscaux et de protection sociale.

Classification JEL : $\mathrm{H} 2$; H23 ; H53 ; I3 ; I38

Mots-clés : Inégalités de revenues ; impôts ; transferts, systèmes de protection sociale ; redistribution ; progressivité ; analyse en cluster

You can copy, download or print OECD content for your own use, and you can include excerpts from OECD publications, databases and multimedia products in your own documents, presentations, blogs, websites and teaching materials, provided that suitable acknowledgment of OECD as source and copyright owner is given. All requests for commercial use and translation rights should be submitted to rights@oecd.org 


\section{TABLE OF CONTENTS}

\section{LESS INCOME INEQUALITY AND GROWTH - ARE THEY COMPATIBLE? PART 3. INCOME REDISTRIBUTION VIA TAXES AND TRANSFERS ACROSS OECD COUNTRIES 5}

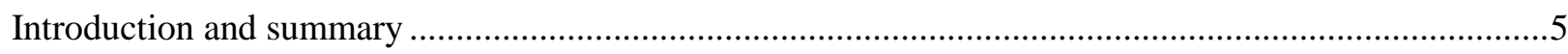

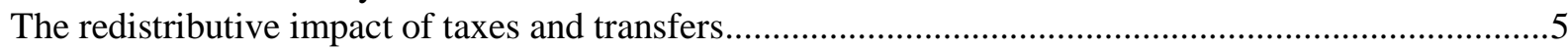

Indicators of tax and transfer policies help identifying reform options and different country models ....6

Trade-offs and complementarities between reducing inequality and promoting economic growth ........7

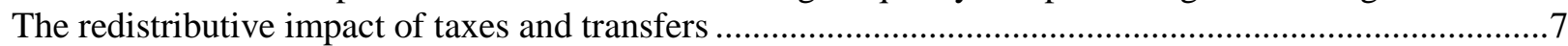

The redistributive impact of cash transfers: cross-country differences and driving forces .....................10

The redistributive impact of pension systems depends on their design ...............................................15

Disability benefits are redistributive but risk creating poverty traps....................................................17

Unemployment benefits are mostly insurance-based and thus not very progressive ..............................18

Family cash benefits are targeted towards low-income groups..........................................................19

The redistributive impact of taxes: cross-country differences and driving forces..................................20

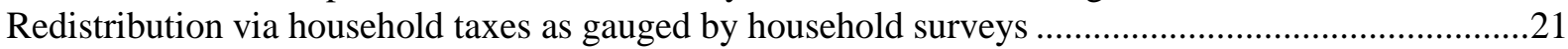

Labour income taxes: progressivity indicators based on statutory tax schedules .................................25

The progressivity of the personal income tax is often hollowed out by tax expenditures.......................28

Taxes on capital income have been reduced and are often lower than taxes on labour income ............29

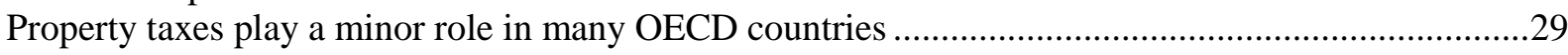

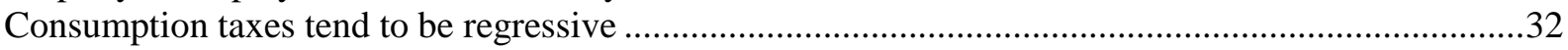

A limitation of the analysis: the incidence of taxes and transfers ......................................................33

Tax and cash transfer policy indicators help identify reform options and types of welfare systems..........34

A set of policy indicators on taxes and cash transfers for each OECD country ....................................35

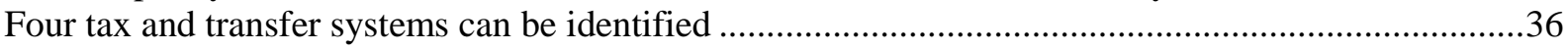

The inequality and growth nexus associated with taxes and transfers .....................................................37

Growth-enhancing tax policy reforms that are likely to reduce income inequality ...............................39

Growth-enhancing tax policy reforms that are likely to raise income inequality ..................................39

Growth enhancing tax policy reforms that have an uncertain impact on income inequality ..................39

The impact of transfer policies on growth very much depends on their design .......................................39

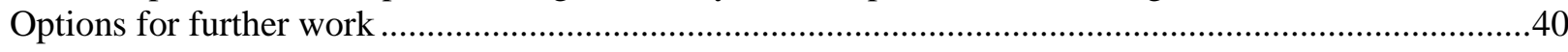

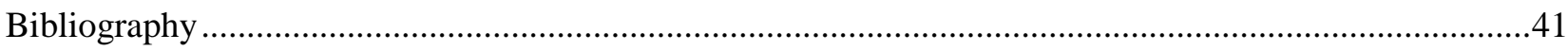

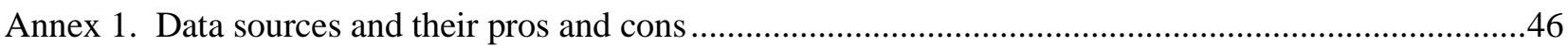

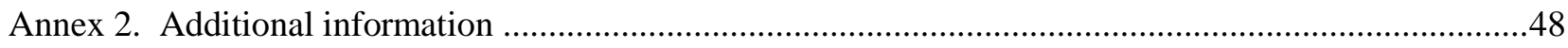

Annex 3. Tax and transfer policies - individual country profiles ............................................................59 


\section{Boxes}

1. Poverty: definition, levels and drivers

2. Welfare systems: Beveridge versus Bismarck? Public versus private? ...........................................11

3. Assessing the redistributive impact of cash transfers and taxes .................................................14

\section{Tables}

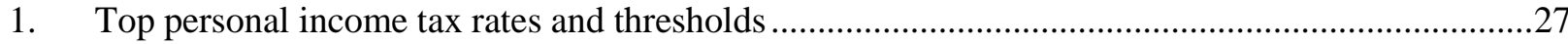

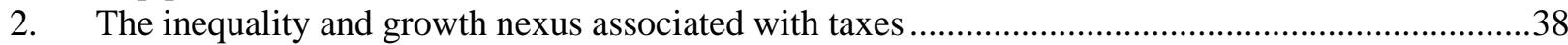

A2.1. Cash transfers by type: redistributive impact, size and progressivity - estimates from household surveys

A2.2. Which taxes and transfers are progressive/regressive? Numerical examples ..................................49

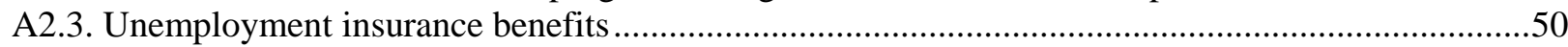

A2.4. Progressivity of unemployment benefits net of taxes .................................................................53

A2.5 Difference in the long-term unemployment net replacement rates between low and

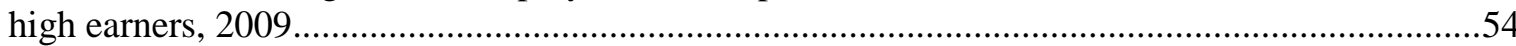

\section{Figures}

1. Taxes and transfers reduce income dispersion, and more so in unequal countries...........................8

2. Cash transfers reduce income dispersion more than taxes .......................................................... 10

3. Public cash transfers to households: level and composition.......................................................12

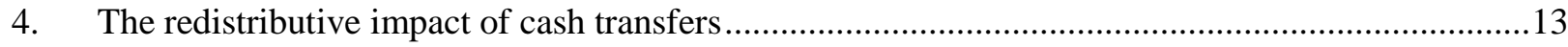

5. Cash transfers: redistributive impact and the contribution of size and progressivity .......................14

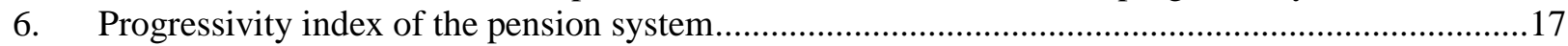

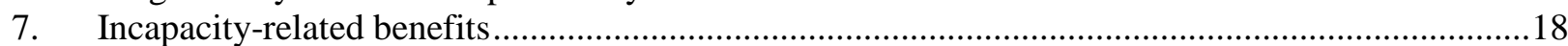

8. Progressivity of unemployment benefits net of taxes ................................................................20

9. Change in the progressivity of initial unemployment benefits for a single person.........................21

10. The redistributive impact, size and progressivity of household taxes ...........................................22

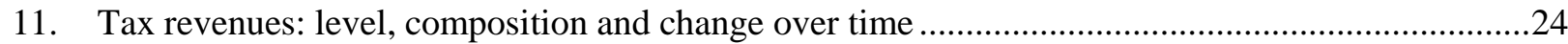

12. Progressivity of statutory personal income tax and employee social security contribution

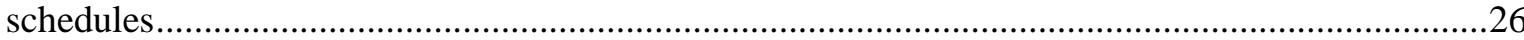

13. The property tax take varies significantly across OECD countries ….........................................30

14. Average consumption tax rate at different income levels...........................................................33

15. Tax and cash transfer policy indicators for Australia and Germany ..............................................35

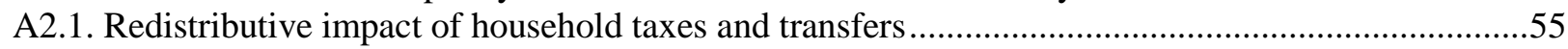

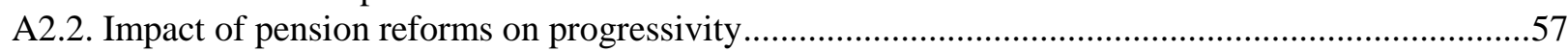

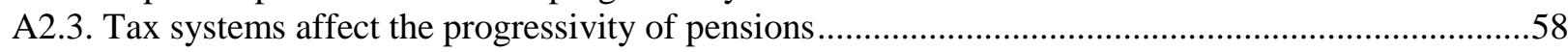

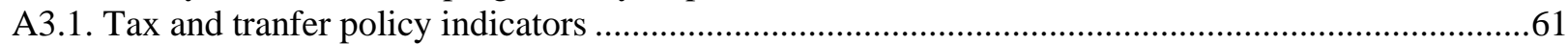

This document and any map included herein are without prejudice to the status of or sovereignty over any territory, to the delimitation of international frontiers and boundaries and to the name of any territory, city or area.

The statistical data for Israel are supplied by and under the responsibility of the relevant Israeli authorities. The use of such data by the OECD is without prejudice to the status of the Golan Heights, East Jerusalem and Israeli settlements in the West Bank under the terms of international law. 
ECO/WKP(2012)3

\title{
LESS INCOME INEQUALITY AND GROWTH - ARE THEY COMPATIBLE? \\ PART 3. INCOME REDISTRIBUTION VIA TAXES AND TRANSFERS ACROSS OECD COUNTRIES
}

\author{
by Isabelle Joumard, Mauro Pisu and Debbie Bloch ${ }^{1}$
}

\section{Introduction and summary}

In many OECD countries, income inequality has drifted up over the past decades (OECD, 2011a). In some countries, top incomes have captured a large share of the overall income gains, while poverty remains a pressing policy issue, not least because of the adverse effects of the recent economic crises. There is a growing consensus that assessments of economic performance should not focus solely on income growth. They should also take into account income distribution, though some see poverty as the relevant concern while others are concerned with income inequality more generally. The Stiglitz-FitoussiSen Commission on economic and social performance, for instance, argued for such a change in perspective. Inclusiveness has also become one of the key issues for the OECD (OECD, 2008a and 2011a). The recent financial and fiscal crises have pushed governments to contain public spending, including cash transfers, while both fiscal consolidation and equity considerations have led some government to raise taxes, in particular on top incomes. Against this background, this paper assesses different tax and transfer policy approaches and investigates complementarities and trade-offs between redistribution strategies and growth-enhancing policies.

The second section of this paper reviews the redistributive impact of taxes and transfers. The third section summarises tax and transfers policy indicators in country profiles and provides an illustration on how these profiles can be used to identify reform options for two OECD countries (Australia and Germany). It also provides a typology of tax and transfer systems, identifying four groups of countries sharing broadly similar features. The fifth section outlines options for future work. The remainder of this section summarises the main findings.

\section{The redistributive impact of taxes and transfers}

Taxes and transfers have a significant redistributive impact. Inequality in income after taxes and transfers, as measured by the Gini index, was about $25 \%$ lower than for income before taxes and transfers on average in the OECD area in the late 2000s. For the same period, poverty measured after taxes and transfers was 55\% lower than before taxes and transfers for the OECD average. Various additional points are worth noting:

1. The authors are members of the Economics Department of the OECD. This paper is one of the background papers for the OECD's project on Income Distribution and Growth-enhancing Policies. The authors would like to thank Peter Hoeller who co-ordinated the project, and also Bert Brys, Oliver Denk, Romain Duval, Jørgen Elmeskov, Michael Förster, Kaja Fredriksen, Isabell Koske, Stephen Matthews and Jean-Luc Schneider for their useful comments and suggestions and Susan Gascard for excellent editorial support. 
- Countries with a more unequal distribution of market income tend to redistribute more.

- Cash transfers reduce income dispersion more than taxes in most OECD countries. On average, three quarters of the reduction in inequality as between market and disposable income are due to transfers, the rest to taxes.

- The redistributive impact of cash transfers varies widely across countries. Countries with a similar dispersion of household market income opt for distinct redistributive strategies. In some, cash transfers account for a large share of household disposable income, redistributing income mainly over the life-cycle rather than across individuals - old-age pensions often fall into this category and their progressivity is low in many countries. Other countries with smaller cash transfers tend to rely more on targeted benefits. And some make little use of cash transfers to reduce income inequality.

- Family and housing benefits are, in most countries, the most progressive cash transfers, though their redistributive impact is limited as they are often small in size. Disability and unemployment benefits reduce income inequality although their degree of progressivity to a large extent depends on their design.

- The cross-country variation in the redistributive impact of household taxes is more limited than that of transfers, despite large differences in tax-to-GDP ratios. High-tax countries tend to have less progressive household taxes.

- The progressivity of labour taxes (including social security contributions) has increased in the majority of OECD countries. Although personal income rate schedules have often become flatter reflecting the steep decline in top marginal tax rates, social security contributions for low-income earners have been cut or tax reliefs made more generous in some countries so as to reduce the cost of labour of groups at high unemployment risk. Furthermore, earned income tax relief has been raised to make work more attractive for low-income earners, raising the progressivity of labour income taxes.

- The personal income tax is the most progressive tax, though there are significant cross-country variations. Social security contributions, consumption taxes and real estate taxes tend to be regressive in most countries.

- Tax expenditures pertaining to personal income tax tend to benefit the well-off, a main exception being in-work tax credits.

- The taxation of capital income, wealth and inheritance has been reduced in many countries, which has reduced the redistributive impact of tax systems.

\section{Indicators of tax and transfer policies help identifying reform options and different country models}

- The redistributive impact of taxes and transfers depends on their size, mix and the progressivity of each component. A set of policy indicators has been compiled which breaks down the redistributive impact of both taxes and transfers into these three dimensions. Individual country profiles facilitate the comparison of each country to the OECD average and thus help identifying reform options.

- Four groups of countries sharing broadly comparable tax and transfer systems have been identified empirically, based on the set of policy indicators: 
- A "Nordic model" characterised by large and mostly universal cash transfers, a high level of spending on in-kind services and a tax mix which promotes redistribution (all Nordic countries and also Belgium are in this group);

- A "Continental European model" characterised by large cash transfers with the lion's share for old-age pensions - i.e. redistributing income mostly over the lifecycle instead of across individuals - and a tax mix which does not promote redistribution across individuals reflecting a small role for the personal income tax (Austria, France and Germany are representative);

- An "Anglo-Saxon model", characterised by small cash transfers, and a tax mix which promotes income redistribution. This model can be divided in two sub-groups: those countries with transfers highly targeted on low-income groups (Australia and New Zealand being examples) and those countries characterised by little progressivity of cash transfers which are largely spent on old-age pensions (Japan and the United States are in this subgroup);

- A lower-income group, where the welfare system is not well developed. Spending on transfers and the level of taxation are considerably below the OECD average, with a heavy reliance on consumption taxes (Chile and Turkey are in this group).

\section{Trade-offs and complementarities between reducing inequality and promoting economic growth}

- The vast literature that has investigated the nexus between inequality and growth is inconclusive. This paper adopts a more tractable approach: it assesses different redistribution strategies and investigates complementarities and trade-offs with growth-enhancing tax and transfer policies. ${ }^{2}$

- A few policies entail a double dividend in the sense that they reduce income inequality while at the same time boosting long-run GDP per capita. In particular, reducing tax expenditures, or eliminating them, and aligning the taxation of capital gains with that of other capital income, could contribute to equity objectives and allow a cut in marginal tax rates.

- Several policies may lower income inequality at the cost of lowering GDP per capita. Higher marginal tax rates on top incomes, wealth, inheritance and inter vivos transfers would increase the progressivity of tax systems but could lower incentives to work, save and invest.

- For several policies that aim at boosting GDP per capita, the income inequality effects are less clear-cut or could even be adverse. Shifting the tax mix to less-distorting taxes - in particular away from labour and corporate taxes to consumption taxes - would improve incentives, but undermine equity objectives.

\section{The redistributive impact of taxes and transfers}

Taxes and transfers are key policy levers to influence distributional outcomes. Information based on household surveys suggests that OECD-wide, taxes and cash transfers reduced the market income dispersion - as measured by the concentration coefficient - by about $25 \%$ and relative poverty by about

2. The policy and non-policy determinants of inequality in individual labour earnings, as well as the complementarities and trade-offs with growth-enhancing labour, product market and education policies are discussed in Koske et al. (2012). 
$55 \%$ in the late 2000s (Box 1). ${ }^{3}$ Their redistributive impact tends to be high in the Nordic countries (Iceland being an exception) and eastern European countries (Figure 1). It is low in Iceland, Korea and Switzerland, all characterised by little market income dispersion, and in Chile. The data suggest that there is a positive link between the redistributive impact of taxes and transfers and the level of market income inequality. Focusing on the working age population yields the same pattern (see Annex 2, Figure A2.1). ${ }^{4}$

\section{Figure 1. Taxes and transfers reduce income dispersion, and more so in "unequal" countries}

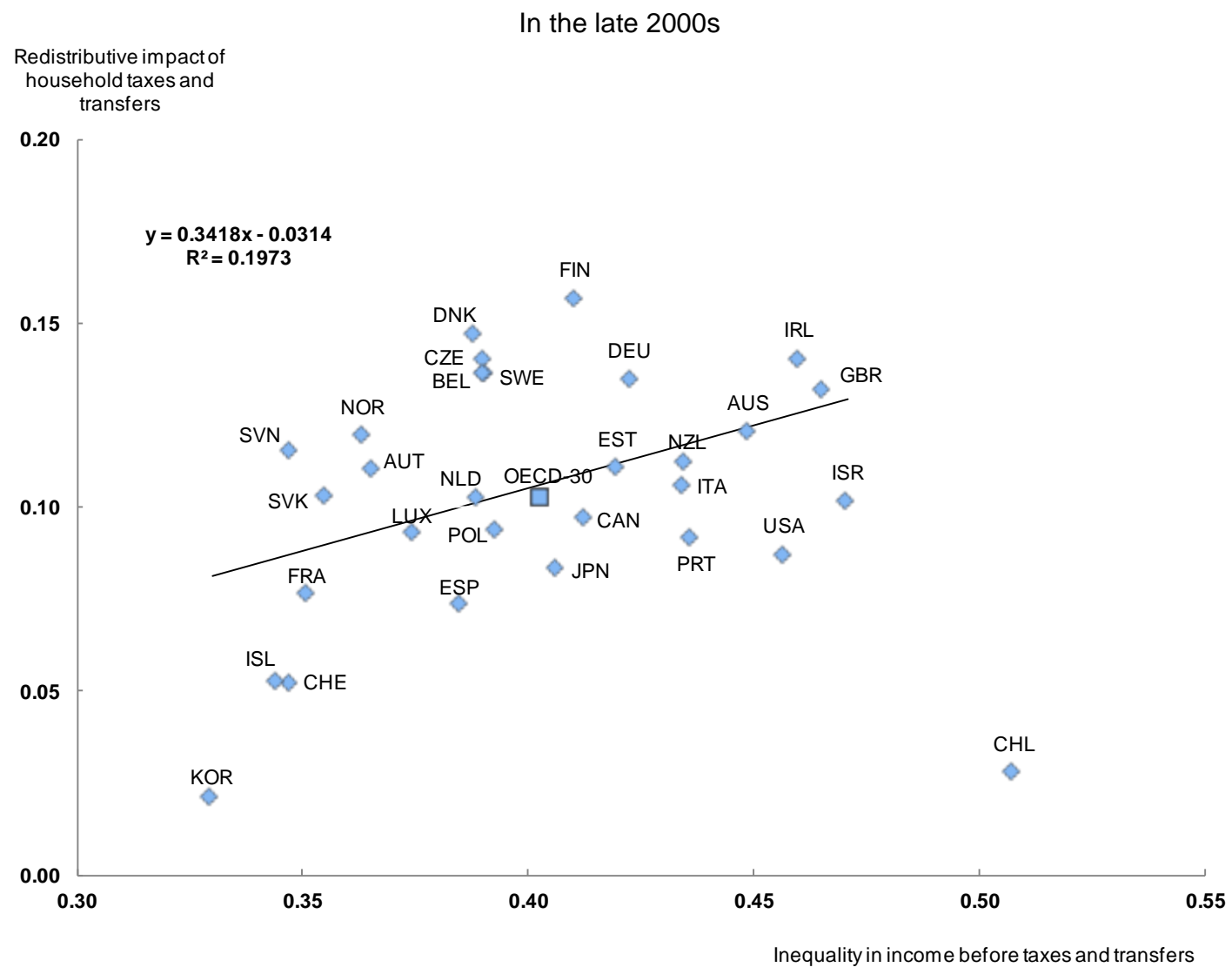

Note: Inequality in income before taxes and transfers is measured by the concentration coefficient. The redistributive impact of taxes and transfers is defined as the difference in the concentration coefficients for income before cash transfers and taxes (i.e. household market income) and after cash transfers and taxes (i.e. household disposable income). Two approaches can be used to measure the concentration of market income, i.e. by ranking households by their market income or by their disposable income. In this illustration, and throughout the paper, households have been ranked by disposable income due to data limitations. Figure A2.1 compares the two approaches. It also shows that the relation between income inequality before taxes and transfers and the redistributive impact of taxes and transfers is stronger when calculating the concentration of market income based on ranking households by market income. Data for France and Ireland refer to mid-2000s. The trend line shown above has been calculated excluding Chile.

Source: OECD Income Distribution and Poverty Database.

3. The OECD Income Distribution and Poverty Database relies on household income surveys carried out by national experts who apply common conventions and definitions, thus enhancing cross-country comparability. In the OECD database, however, income data for Greece, Hungary, Mexico and Turkey are presented net of taxes and data on household taxes are not available. Data from household surveys face other limitations, discussed in Annex 1.

4. When assessing the redistributive impact of taxes and transfers, most analyses (including this paper) assume that taxes and transfers do not affect economic behaviour. Incidence issues are discussed at the end of this section. 


\section{Box 1. Poverty: definition, levels and drivers}

In addition to inequality per se, poverty is an important policy issue (OECD, 2008a). The poverty rate is defined here in relative terms, as the percentage of individuals with income below $50 \%$ of the median equivalised household disposable income. In some countries, most notably in the United States, official poverty statistics are based on an absolute poverty threshold. However, a consensus has emerged favouring the use of relative poverty measures, at least in the context of developed countries (Sen, 1983). One of the purported advantages of the relative measure is that it relates more closely to the concept of capability deprivation (Sen, 1992).

Drifting up over the past two decades, the OECD-wide poverty rate stood at $11 \%$ in the late 2000s (Pisu, 2012). There is considerable variation, with poverty ranging from about $6 \%$ in the Czech Republic, Denmark, Hungary and Iceland to above $15 \%$ in Chile, Israel, Japan, Mexico, Turkey and the United States. In addition, poverty varies considerably across age groups; children (individuals below 18 years old) and the elderly (over 65 years) suffer from higher poverty rates than working-age individuals. ${ }^{1}$ The poverty rate of women is higher than that of men in most OECD countries. The difference is more pronounced for pension-age than working-age women as a result of lower labour market participation of women, especially in the past (and thus less pension rights), and their longer life expectancy (OECD, 2008a).

Labour market participation lowers poverty but is no guarantee to escape it. In-work poverty is especially pronounced in households with a sole worker and much less so for households with two or more workers. In most countries, the poverty incidence in households with children is higher than in childless ones.

Taxes and transfers can be effective in reducing poverty. They contribute most to contain poverty rates in the Czech Republic, France and Ireland and least in Korea, Mexico and Chile. The cross-country variation in the reduction of poverty rates is mainly explained by the targeting and size of public cash transfers, with household taxes having little effect. Overall, countries that achieve a greater reduction in poverty are those redistributing more towards low-income groups. However, not all poor households benefit from redistribution to the same extent. Taxes and transfers reduce the poverty rate more for households with children.

1. The poverty rate does not reflect house ownership and associated imputed rents which may be high for pensioners. Additionally, in-kind transfers (health care services or public transport) are sometimes provided at a lower price or for free to pensioners. The poverty rate of older people may thus be overestimated in some countries.

Cash transfers reduce income dispersion more than taxes (Figure 2). ${ }^{5}$ The United States, however, is an outlier with virtually the same redistribution achieved through taxes as cash transfers. It relies heavily on the tax code to provide support to low-income groups - the Earned Income Tax Credit is one of the largest US social programmes - while other countries rely more on cash transfers. ${ }^{6}$

The redistributive impact of taxes does not vary widely across countries, despite large cross-country differences in the size of the tax take and progressivity of the tax system. Some countries have opted for a high tax take but, as they are constrained to tax virtually all citizens, with little progressivity. Others have a smaller but more progressive tax system. By contrast, the redistributive impact of transfers displays large cross-country differences. In Denmark, Finland and Sweden, it is more than five times higher than in Korea and about three times higher than in the United States. However, the annual income distribution data may overstate significantly the degree of redistribution across individuals as social security schemes have a - sometimes large - component that provides redistribution over the lifetime rather than redistributing across individuals (Box 2). Countries that spend the most on cash transfers tend to concentrate more on redistribution across the life-cycle (in particular through old-age pensions). In contrast, those countries that focus more on redistribution between the rich and the poor, through extensive use of targeting, spend less.

5. Looking at the working age population yields broadly the same message.

6. In the OECD Income Distribution and Poverty Database, the Earned Income Tax Credit is booked as a transfer. 
Figure 2. Cash transfers reduce income dispersion more than taxes

Point reduction in the concentration coefficients, in the late 2000 s

Redistributive impact of household taxes

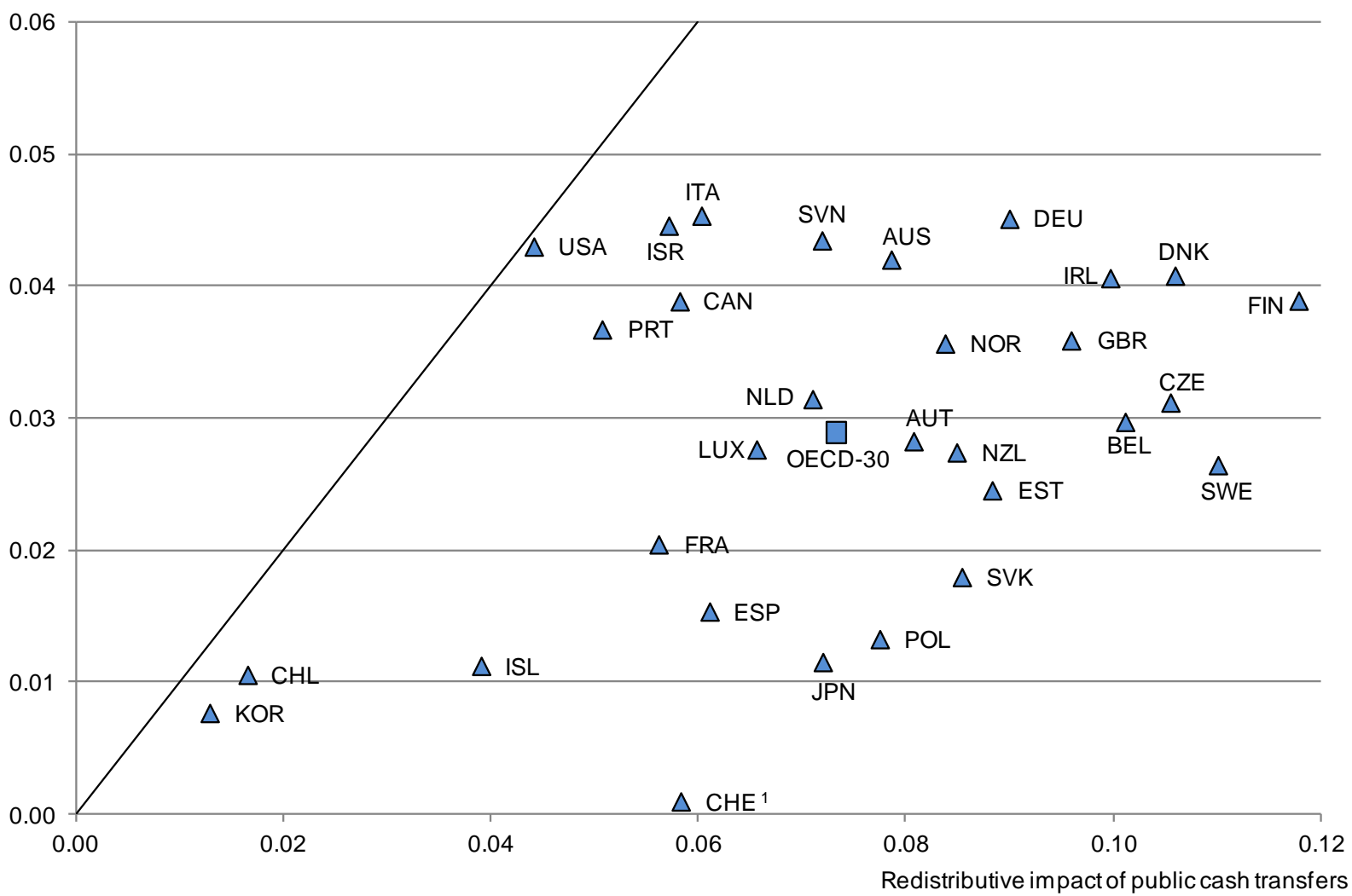

1. The redistributive impact of household taxes for Switzerland is slightly negative $(-0.006)$, but has been set to zero.

Note: The redistributive impact of public cash transfers is measured as the difference between the concentration coefficient of market income and that of income after transfers. The redistributive impact of household taxes is measured as the difference between the concentration coefficient of post-transfer income and that of disposable income (i.e. post-tax and transfers). Data for France and Ireland refer to mid-2000s.

Source: OECD Income Distribution and Poverty Database.

\section{The redistributive impact of cash transfers: cross-country differences and driving forces}

The redistributive impact of cash transfers is large but varies a lot across countries

The main features of the size and redistributive impact of cash transfers are as follows:

- On average across the OECD, cash transfers amounted to $11 \%$ of GDP and $20 \%$ of household disposable income in 2007 (Figure 3). They reduced income inequality as measured by the fall in concentration of market income before and after transfers by about $19 \%$ in the late 2000 s. Those countries that spend the most are not always those where the redistributive impact is strongest. Cash transfers ranged from 2 $1 \frac{1}{2}$ per cent of GDP in Mexico and Korea to over $17 \%$ in Austria. In Austria, however, the redistributive impact is close to the OECD average.

- There is no clear link between the degree of market income inequality and the redistributive impact of transfers - the most unequal countries do not redistribute more (Figure 4, Panel A). The redistributive impact is highest in the Czech Republic, Finland, Sweden and Denmark, all characterised by a dispersion of market income close to the OECD average. The redistributive 
impact of cash transfers is especially low in Korea and Chile, followed by Iceland, the United States and Portugal. Moreover, countries with a similar dispersion in household market income (e.g. Finland and Canada) can opt for distinct redistributive strategies - the redistributive impact of cash transfers in Finland is about twice as large as in Canada.

\section{Box 2. Welfare systems: Beveridge versus Bismarck? Public versus private?}

In most OECD countries, welfare systems have three main objectives:

- Redistributing income over the life-cycle (from working-age to retirement age), with public old-age pensions largely financed out of social security contributions or general taxation.

- Providing income maintenance or insurance to cope with adverse risks, such as unemployment, disability and sickness.

- Avoiding poverty or a too wide dispersion in living standards, with benefits financed mostly out of general taxation. These benefits can be either universal or means-tested.

Bismarckian-type welfare states rely on social insurance, with benefits financed out of social security contributions. They give priority to the first two objectives. Beveridgean-type welfare states give priority to the third objective with social benefits targeted on those in need and financed by tax revenues. A third welfare model, as recognised by Esping-Andersen (1990), is implemented in the Nordic countries. It involves universal benefits involving a "de-familialisation" of welfare responsibilities, with a complete coverage both for child and elderly care and thus a high level of taxation. In practice, welfare systems involve a mix of redistribution between the rich and the poor, risk insurance and lifetime redistribution. They also often provide both means-tested and universal benefits. These features, however, differ between countries. In a comparative study, Stahlberg (2007) estimated that in Australia $38 \%$ of lifetime benefits received by individuals were financed through taxes they paid at another stage of their life-cycle, and the remaining $62 \%$ involved redistribution between the rich and the poor. In Sweden, $18 \%$ of lifetime benefits involved redistribution between individuals and $82 \%$ involved redistribution over different phases of the life-cycle of an individual. Sweden, as the other Nordic countries, relies heavily on universal benefits while Australia relies more on targeted and means-tested transfers. The choice between targeted and means-tested transfers is often reflected in tax rates: means-tested benefits can generate high marginal effective tax rates during the withdrawal phase, whereas universal benefits generally lead to high average tax rates because they are costly.

Cross-country differences in the public/private nature of insurance mechanisms and in the taxation of social benefits are also important. Some countries rely mostly on private pension funds to ensure income redistribution across the life-cycle and, often to a lesser extent, on private insurance companies to provide insurance against health risks. Because contributions to, and benefits received from, private funds are not considered as part of the redistributive system, the size of the welfare system is smaller than in the countries which rely mostly on public coverage. At the same time, the countries that rely more on private schemes may display more progressive public schemes since these do not include pensions and other benefits governed by insurance mechanisms, which often benefit lower income households less. The taxation of social benefits also affects cross-country comparisons. In some OECD countries, transfers are subject to broadly the same tax treatment as wage income (e.g. Nordic countries) while in others (e.g. Japan) they are largely untaxed. Adema and Ladaique (2009) provide estimates for net public social expenditure, i.e. adjusting for the impact of the taxation of social benefits and tax breaks with a social purpose as well as for indirect taxes. This leads to a reassessment of the magnitude of welfare states and to a greater similarity in social expenditure-to-GDP ratios across countries.

- The cross-country variation in the redistributive impact of cash transfers reflects differences in the size and progressivity of these transfers (Box 3). Figure 5 suggests that countries obtain a similar redistributive impact through drastically different size and progressivity combinations (Figure 4, panel B). For instance, in Portugal and the United States transfers attain about the same reduction in inequality but for different reasons. In the United States, the limited reduction in inequality is due to the smaller size of transfers compared with the OECD average whereas in Portugal it is mainly due to their lower progressivity.

- From the mid-1990s to the late 2000s, the redistributive impact of cash transfers slightly weakened on average for the 19 countries for which data are available. This decline is due to a lower size, 
partly due to a reduction in unemployment, whereas progressivity increased. The lack of, or incomplete, indexation of cash transfers has impinged negatively on their generosity. The examination of 10 countries suggests that incomplete indexation of benefits resulted in recipients losing ground in a majority of these countries (OECD, 2011a). The choice of indexation - to prices versus wages - affects the income loss, which is often more pronounced at lower income levels. ${ }^{7}$

- The progressivity of transfers varies significantly across benefit schemes (Annex 2, Table A2.1). It tends to be lower for old-age and disability pensions as well as unemployment benefits than for family and housing benefits. The transfer mix thus plays a role in explaining cross-country differences.

\section{Figure 3. Public cash transfers to households: level and composition ${ }^{1}$}

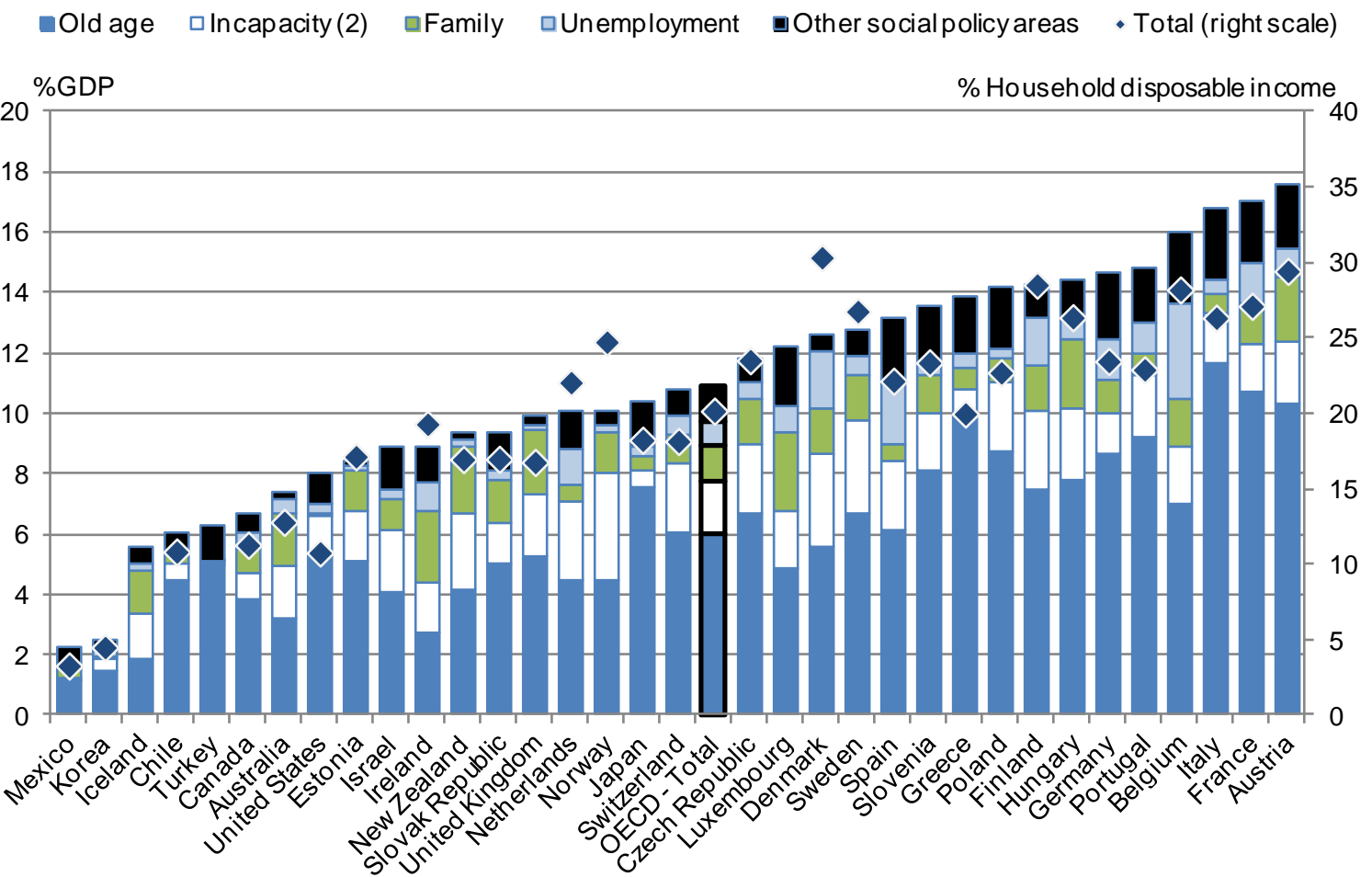

1. The data shown here exclude private mandatory spending which accounts for an important share of total social spending in some countries (in particular Chile, Germany and Switzerland). In addition, public cash transfers shown here may not fully account for those programmes and services provided, or cofinanced, by local governments. Measurement gaps may be high, notably in federal countries such as Canada.

2. Incapacity-related spending covers expenditure on disability pensions and sick leave schemes (occupational injury and other sickness daily allowances).

Source: OECD Social Expenditure Database.

7. As an example, social transfers targeted at low-income groups in France - the minimum income (RMI/RSA) and minimum pensions - are only adjusted for price inflation. As the average wage has grown more rapidly than prices over the past decade, the relative income of social transfer recipients has declined substantially, undoing the discretionary measures to improve their generosity (Conseil des Prélèvements Obligatoires, 2011). 
ECO/WKP(2012)3

Figure 4. The redistributive impact of cash transfers

In the late 2000 s

A. Unequal countries do not redistribute more through cash transfers

Redistributive impact of transfers

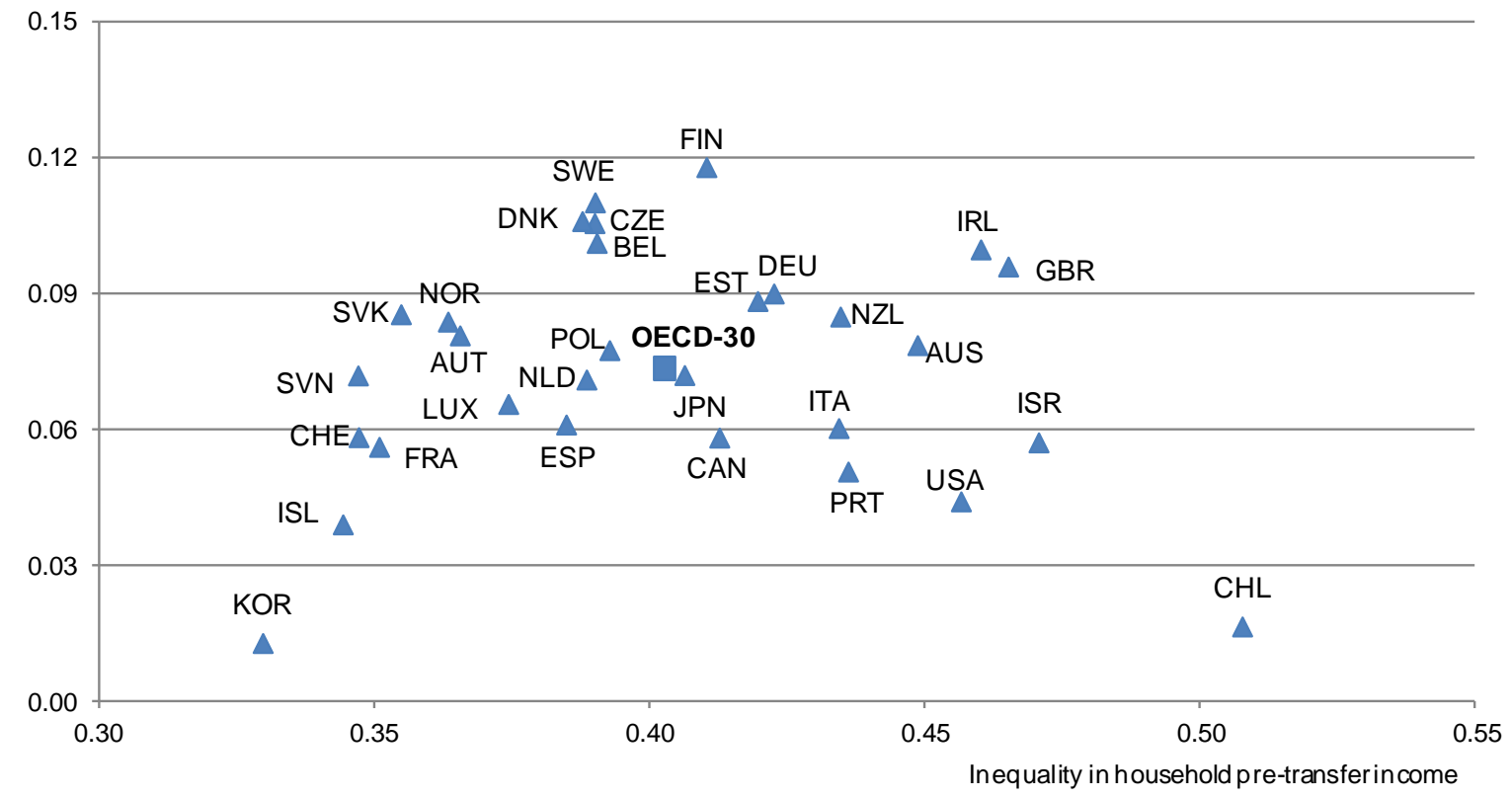

B. Countries with large cash transfers tend to have less progressive systems

Progressivity index of cash transfers

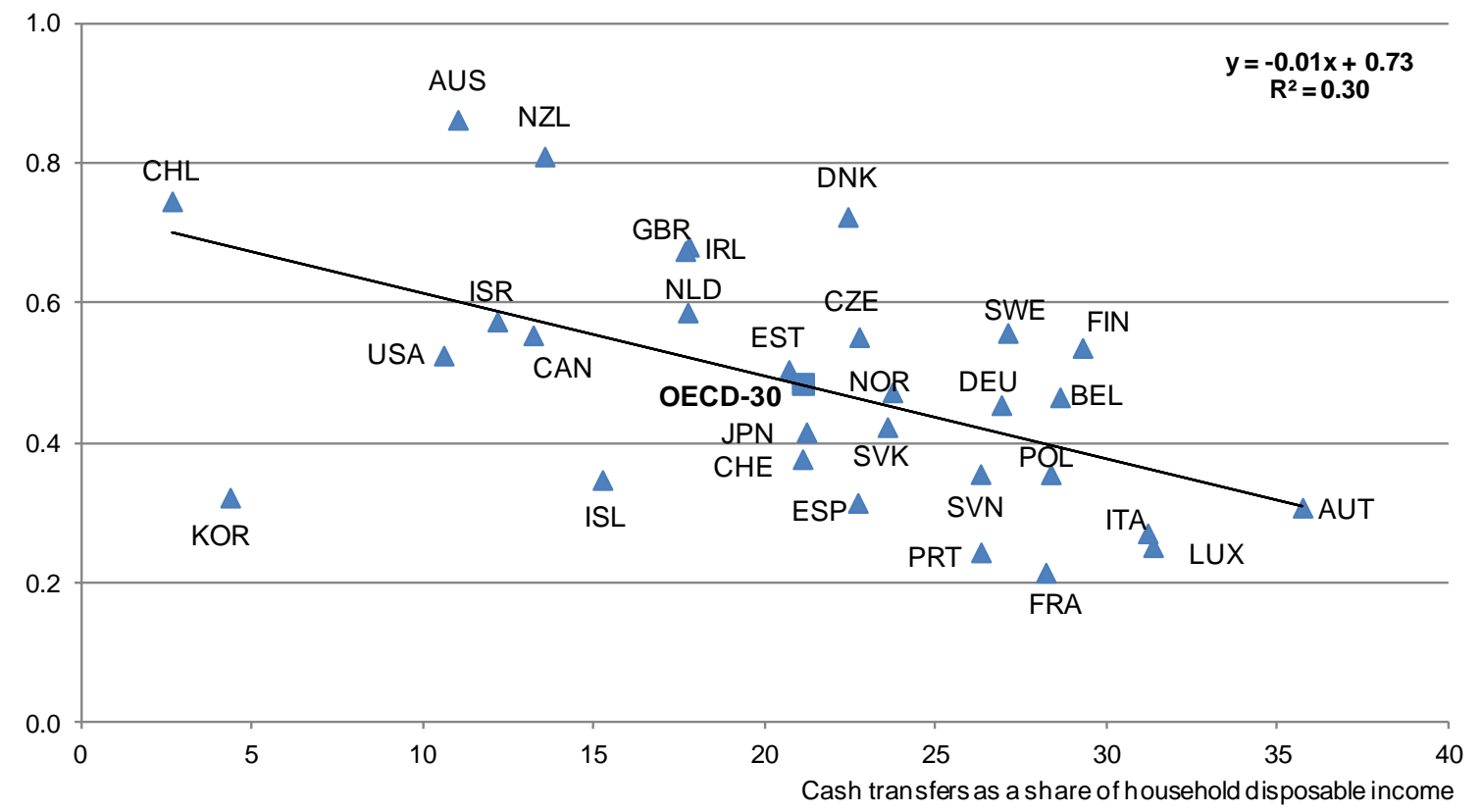

Note: Inequality in household pre-transfer income is measured by the concentration coefficient for household market income. The redistributive impact of cash transfers is measured as the difference between the concentration coefficient of market income and that of market income after transfers but before taxes. The progressivity index of cash transfers is the Kakwani index, defined as the concentration coefficient for market income less the concentration coefficient for transfers (see Box 3). Data for France and Ireland refer to the mid-2000s.

Source: OECD Income Distribution and Poverty Database. 
Figure 5. Cash transfers: redistributive impact and the contribution of size and progressivity

In the late 2000s, working age population

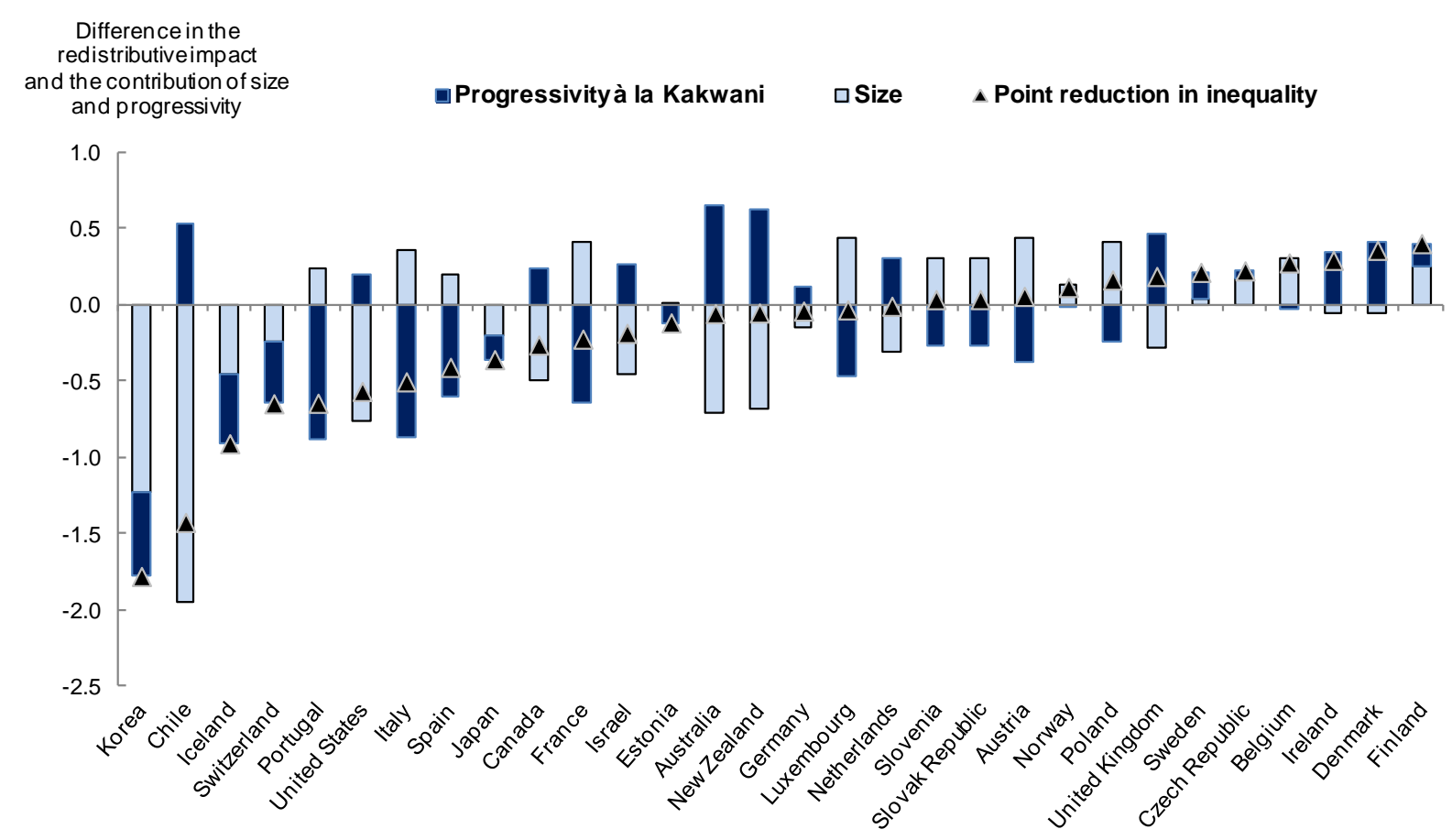

Note: Countries on the right side are those where cash transfers have the largest redistributive impact. The triangles compare the redistributive impact for each country with the OECD average. These data correspond to the log difference in the point reduction in inequality which can be attributed to cash transfers in a given country relative to the OECD average (the log difference is a proxy for the percentage difference for small values, i.e. for most countries shown in this chart except Korea and Chile). The bars indicate the percentage contribution of size and progressivity to the log difference in the point reduction in inequality relative to the OECD average. As an illustration, the triangles show that Portugal and the United States achieve broadly the same reduction in inequality through transfers, both being below the OECD average. The bars show that, in the United States, the limited reduction in inequality is due to the small size of transfers (compared with the OECD average) whereas in Portugal it is attributable to their low progressivity (compared with the OECD average). Data for France and Ireland refer to the mid-2000s.

Source: OECD Income Distribution and Poverty Database.

\section{Box 3. Assessing the redistributive impact of cash transfers and taxes}

Various measures can be used to assess the redistributive impact of cash transfers and tax systems. Three are used extensively in this paper: the concentration coefficient, the difference in income dispersion before and after redistribution, and a progressivity measure.

The concentration coefficient for cash transfers provides an indication of who receives the transfers. It is zero when everyone receives the same transfer. The concentration coefficient is negative when the poor receive more in absolute terms than the rich - e.g. when benefits are means-tested - and becomes positive when the rich receive more in absolute terms (e.g. old-age pensions). Even in the latter case, there may be redistribution if market income is distributed more unevenly. Likewise, the concentration coefficient for taxes provides an indication of who pays the taxes across the income distribution. If the richest pay most of the taxes, the concentration coefficient will be high. Still, the concentration coefficient for taxes reflects not only the progressivity of the tax system but also the dispersion of pre-tax income. A more unequal country will raise more tax revenues from the wealthy and less from the poor. It will therefore show a higher concentration coefficient even if it features the same tax system as the less unequal country.

The redistributive impact of cash transfers and taxes is best measured by the difference in the concentration coefficients for income before and after cash transfers and taxes (Musgrave and Thin, 1948; Norregaard, 1990). It 
depends on both the size of cash transfers and taxes and their progressivity (Kakwani, 1977 and 1979).

The redistributive impact of cash transfers can be expressed as:

Concentration coefficient of market income plus transfers - Concentration coefficient of market income

It is also equal to:

Size of cash transfers * Progressivity of cash transfers (Kakwani index)

where the size of cash transfers is measured as their share in market income plus transfers and the Kakwani index is defined as (Concentration coefficient of cash transfers - Concentration coefficient of market income, i.e. before taxes and transfers).

The redistributive impact of taxes can be expressed in the same way:

Concentration coefficient of disposable income - Concentration coefficient of market income plus transfers

And it is also equal to:

Size of taxes * Progressivity of taxes (Kakwani index)

where the size of taxes is measured as their share in household disposable income and the Kakwani index is defined as (Concentration coefficient of taxes - Concentration coefficient of market income plus transfers).

A tax is considered to be progressive when high-income groups face a higher average tax rate than low-income groups (relative progressivity). In some cases, e.g. as regards consumption taxes, high-income groups pay a higher amount of taxes than low-income groups (absolute progressivity) but still face a lower average tax rate. Taxes are then considered as regressive and the Kakwani index becomes negative. Similarly, cash transfers are considered to be progressive when they account for a larger share of the low income groups' income. This definition implies that flat cash transfers (e.g. a minimum pension for all) are considered to be progressive. And cash transfer programmes which benefit the rich most in absolute terms (e.g. subsidies for tertiary studies) are still considered as progressive as long as the share of these transfers in household income is lower for high-income than for low income groups. Table A2.2 provides numerical examples.

In measuring the redistributive impact of taxes and cash transfers, it is assumed in this paper that cash transfers are received first and taxes paid afterwards, an approach consistent with OECD (2008a). Indeed, benefits are taxable in many countries. Thus, assessing the redistributive impact of taxes by comparing the concentration coefficient of market income and the concentration coefficient of market income minus taxes would distort the picture - the tax system would appear more regressive than it is. However, in some countries benefits are largely set on the basis of after-tax market income. In this case, comparing the concentration coefficients for market income and for market income plus transfers results in a biased measure of the redistributive impact of benefits. In a study on 14 OECD countries (Immervoll and Richardson, 2011), the measurement approach is chosen to reflect, as far as possible, the actual legal sequence implicit in each country's tax and benefit system. In particular, the redistributive impact of taxes is determined by comparing Gini indices of market income and net-of-tax income for Australia, the Czech Republic, Germany, Israel and the United States. This option only partly solves the problem since some of the benefits are taxable in these countries (e.g. pensions and unemployment benefits in the United States). Overall, however, a simulation carried out on two countries (France and the United States) suggests that a different sequencing does not alter significantly the estimated redistributive impact of taxes (or transfers).

\section{The redistributive impact of pension systems depends on their design}

Old-age pensions account for the largest share of total cash transfers $-55 \%$ in the mid-2000s for the OECD on average. Unsurprisingly, for people above 65, they accounted for the bulk (more than 90\%) of total transfers received, but for working-age people, their share was also large: $37 \%$ for the OECD average but around $80 \%$ in Italy and $60 \%$ in Poland. ${ }^{8}$ Old-age pensions can be sub-divided into three tiers (OECD,

8. The high share of pensions received by working age individuals in some countries is attributable to the low effective retirement age. There is a negative correlation between this share and the standard or effective 
2011c). The first two tiers are mandatory whereas the third is voluntary. The first tier has a redistributive function and is publicly provided. The second tier plays mostly an insurance or income-replacement role, ensuring a living standard comparable to that prior to retirement. The third tier reflects voluntary pension arrangements, and is thus likely to have little or no redistributive impact.

The OECD has produced a progressivity index for mandatory old-age pensions. For flat basic pensions, the index reaches 100 (OECD, 2011a; Whitehouse, 2006). New Zealand and Ireland are the only OECD countries where public pensions are flat and universal payments, without second-tier schemes and thus are considered as the most progressive pension system (Figure 6). Other countries with highly progressive pension systems are Canada, the United Kingdom, Israel, Korea and the Czech Republic. On the other hand, Sweden has a regressive mandatory pension scheme, due to the U-shaped profile of the replacement rate. ${ }^{9}$ Some of the southern and eastern European countries, as well as Finland and the Netherlands, also show little progressivity. Among these countries, Italy and Poland now have defined-contribution second-tier pensions, which have been specifically designed to forge a strong link between contributions and benefits -i.e. redistribution over the life-cycle instead of across individuals.

Differences in mortality rates across individuals and the design of tax systems - two issues not covered by the progressivity index above - often reduce the progressivity of pensions. Low-income earners tend to die at a younger age than high-income earners (e.g. Waldrom, 2007; Christia, 2007; Marmot and Shipley, 1996). The shorter average life span of low-income individuals reduces particularly the progressivity of contributive insurance-type pension systems, as part of low-income earners' contributions ultimately finance pension payments of high-income earners. ${ }^{10}$

Taxes and social security contributions can affect the progressivity of pensions, and therefore the degree of redistribution they achieve, substantially (Keenay and Whitehouse, 2003). Pension income is in general taxed at lower rates than work-related income because: $i$ ) the personal income tax is progressive and gross replacement rates are generally below $100 \%$; ii) pensioners are often exempted from certain types of social security contributions or pay them at a reduced rate. The effect of taxes on pension progressivity can be gauged by comparing the gap between gross (before taxes) and net (after taxes) replacement rates for low and high-income earners. ${ }^{11}$ Figure 6 shows that taxes and social security contributions slightly reduce the progressivity of retirement-income schemes on average across the OECD. Still, in 15 out of the 34 countries, taxes and social security contributions enhance the progressivity of pensions.

retirement age. The correlation coefficient between them is 0.61 (based on data for the mid-2000s) and is statistically significant at the $1 \%$ level.

9. In Sweden, the replacement rates of mandatory pensions are progressive for a large part of the income distribution. The replacement rate declines with income up to a certain income level beyond which it starts to increase. Also it is worth emphasizing that pension systems with high payments can be characterised by low overall progressivity and vice versa as progressivity basically depends on the difference in replacement rates between low- and high-income earners and not on the level of replacement rates.

10. Empirical evidence corroborates this (Garrett, 1995, Goda et al., 2009 for the United States and Hachon, 2009 for France). Hachon (2009) shows that, for sufficiently large differences in mortality rates, insurance-based pension systems can become regressive.

11. In pure flat pension schemes, the replacement rate of benefits decreases monotonically whereas in pure insurance schemes the replacement rate is constant across the earnings distribution. In general, a pension scheme will be more redistributive the larger the difference between the replacement rate of low and high pensions. Although this is a rough progressivity measure, as it does not take into account the inequality in personal earnings, the correlation coefficient between this progressivity measure and the progressivity index used for Figure 6 is 0.85 . 
Figure 6. Progressivity index of the pension system ${ }^{1}$

2008, pensions before tax

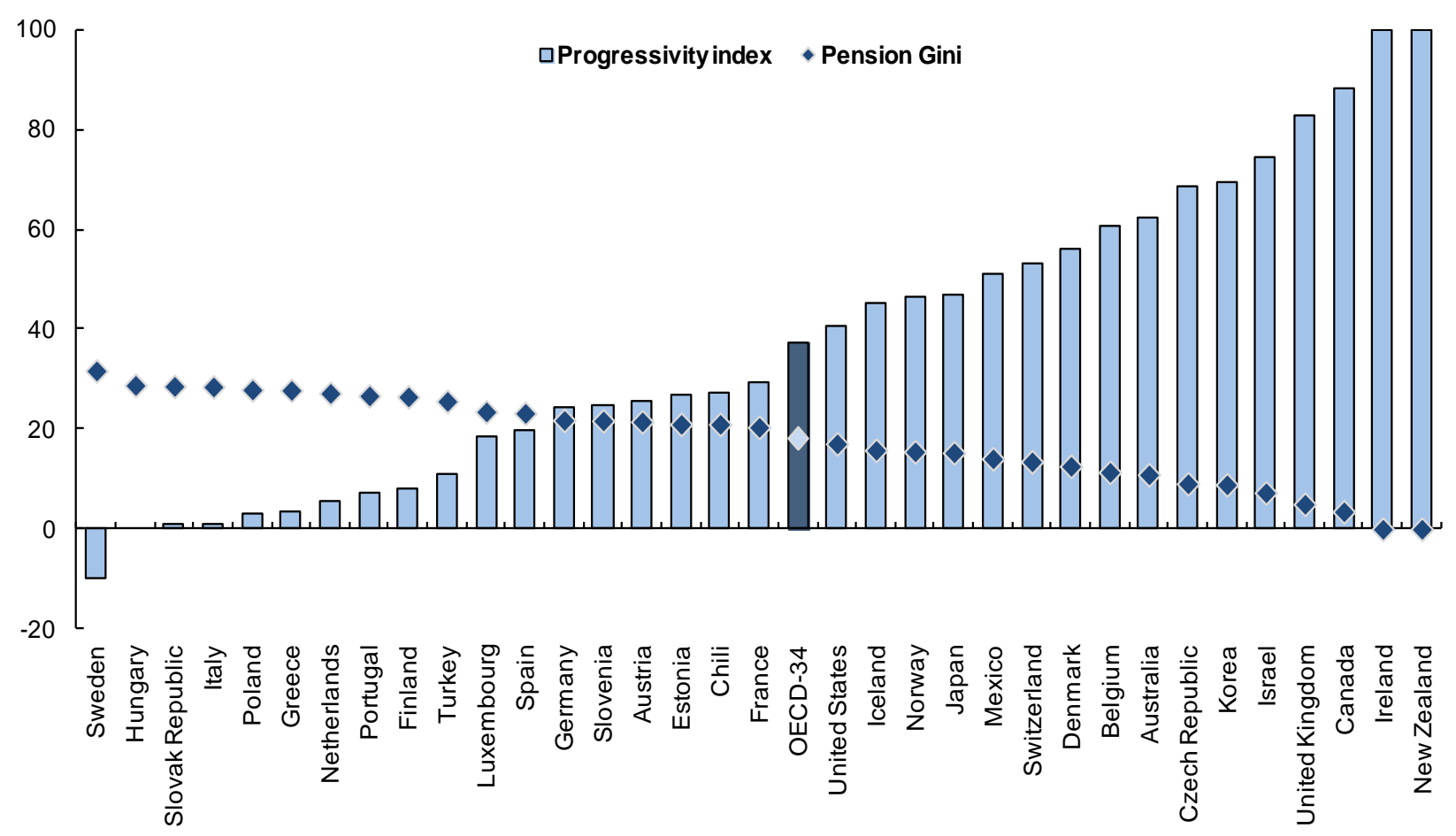

1. The progressivity index is calculated considering only the mandatory part of the pension system plus the quasi-mandatory parts with broad coverage. For instance, in Denmark and Sweden there are quasi-mandatory, occupational defined-contribution schemes with broad coverage that are included in the index. The index shown here is not a Kakwani index. It is based on pension systems' parameters and is computed as 100 minus 100 times the ratio of the Gini of pension payments to the Gini of personal gross earnings in 2008. The Gini indices are calculated using the OECD average earnings distribution. Pension entitlements are computed using the OECD pension model and refer to workers entering the labour market in 2008 . The calculations are based on the rules applying in 2008. They include the effects of pension reforms legislated by 2008 but to be phased in later. The pension Gini is the Gini index for pension payments multiplied by 100.

Source: OECD pension models and OECD (2011c), Pensions at a Glance 2011.

Over the past two decades, pension reforms have slightly reduced pension progressivity on average for the 20 countries for which data are available (OECD, 2009; Whitehouse, 2009), though there was again wide cross-country heterogeneity. The drop in the progressivity of pensions in countries such as the Slovak Republic, Poland and Hungary (Annex 2, Figure A2.2) is partly due to the introduction of defined-contribution schemes, which provide a stronger link between pensions and earnings. On the other hand, pension reforms which increased the number of years required to calculate the earnings basis for pension payments (in addition to raising the effective retirement age) have tended to make pension systems more progressive, because higher income individuals typically have a steeper wage profile over their working life.

\section{Disability benefits are redistributive but risk creating poverty traps}

Cash transfers associated with disability and sickness benefits are also large. They amounted to $2 \%$ of GDP on average in the OECD in 2007 and reached more than $3 \%$ in the Nordic countries and the Netherlands (Figure 7). In 2007, around 6\% of the working-age population received such benefits on average across the OECD, and in some countries this share was well above the unemployment rate $(\mathrm{OECD}, 2010 d)$. During the past 10-15 years, the number of recipients increased in around half of the OECD countries partly reflecting the use of disability programmes to soften the impact of downturns 
(Benítez-Silva et al., 2010) and, to a lesser extent, population ageing. The increase also reflects a shift away from early retirement schemes and unemployment benefits as governments have tightened the eligibility criteria of these programmes.

Figure 7. Spending on incapacity-related benefits

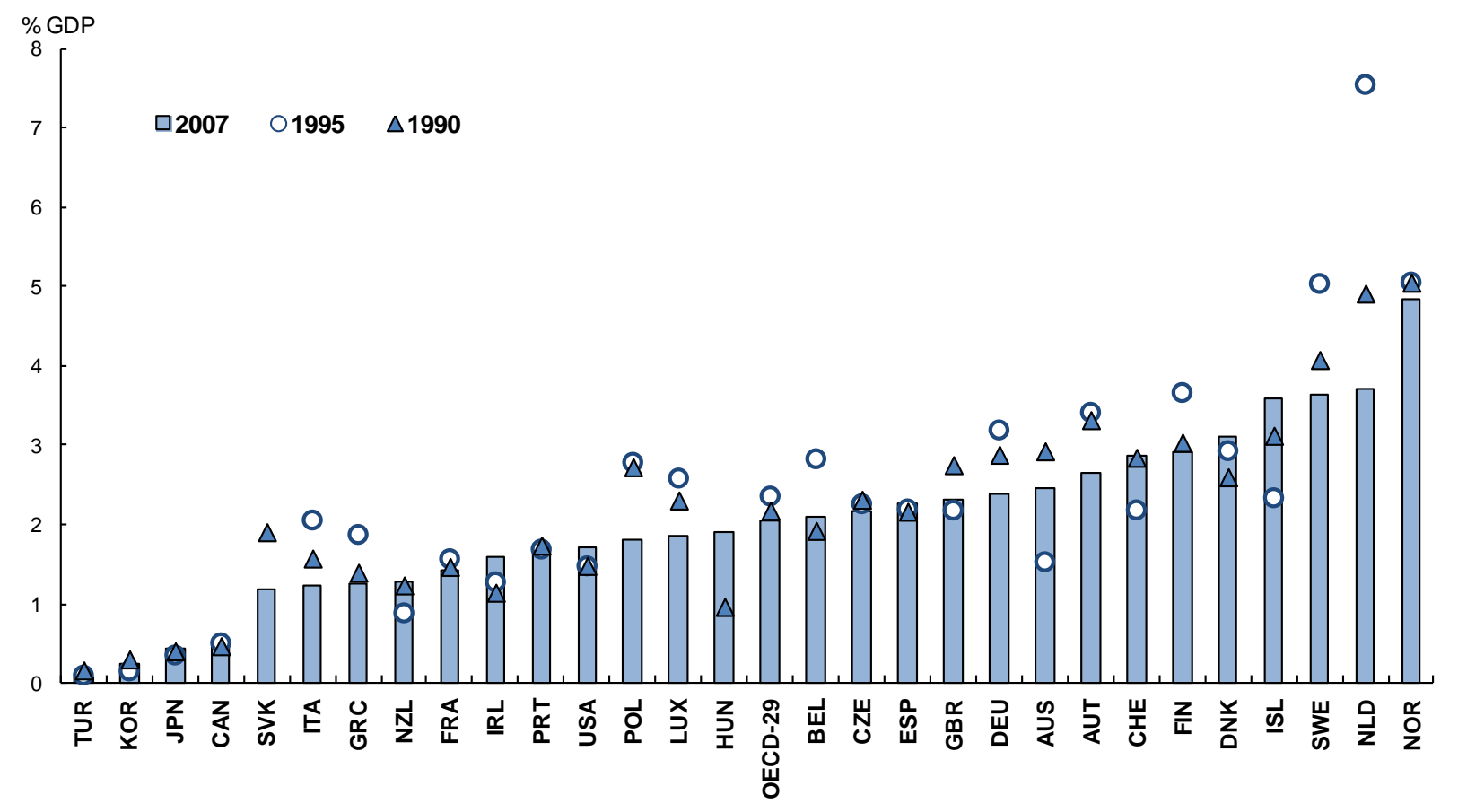

Note: Figures include public and private disability pensions and paid sick leave schemes (occupational injury and other sickness daily allowances). Data for Canada do not include spending on provincial social assistance payments with a disability designation (which would roughly double the spending figure), nor spending on voluntary private long-term disability plans. Data for Australia refer to 2005.

Source: OECD (2010d), Sickness, Disability and Work: Breaking the Barriers, Table 2.1.

Although disability benefits reduce income inequality at a given point in time, as net replacements rates for low-wage earners are higher than for high-wage earners (OECD, 2010d), they may increase lifetime income inequality by reducing income mobility and creating poverty traps. Across the OECD, disability benefits are often the only means of sustenance for people with a disability but often do not suffice to escape poverty. ${ }^{12}$ People receiving disability benefits indeed have lower employment and higher unemployment rates than people with no disability. Many countries have thus started to reform disability benefits to reach a better, and more sustainable, balance between income security and labour market (re-)integration of disabled people.

\section{Unemployment benefits are mostly insurance-based and thus not very progressive}

The redistributive effect of unemployment benefits depends on the system's parameters including eligibility criteria, replacement rates for low and high-income earners and benefit duration. These benefits are conditional on past contributions and are earnings-related in most countries (Annex 2, Table A2.3). Greece, Iceland, Ireland, Poland and the United Kingdom are exceptions since they provide flat, though

12. On average in the OECD, $22 \%$ of households with a disabled person receiving benefits live in poverty, compared with around $14 \%$ for other households. This gap is especially high in Australia, Ireland, Korea, the United Kingdom and the United States (OECD, 2010d). 
relatively low benefits, enhancing the redistributive impact of unemployment benefits. Many countries impose a ceiling on unemployment benefits, thus also introducing an element of progressivity, but it may be high whereas in a few others, there is no upper limit.

The progressivity of unemployment benefits can be gauged by comparing the net replacement rates of low and high-income earners. Figure 8 shows that unemployment benefits for the initial phase of unemployment tend to be progressive, with a wide cross-country variation. ${ }^{13}$

Unemployment benefits have become slightly more progressive over the past decade, in particular in those countries where they were initially less progressive (Figure 9). In contrast, progressivity has declined in countries where the systems were the most progressive.

Most OECD countries also operate minimum-income programmes as a last-resort safety net (Immervoll, 2010). The benefit level is unrelated to previous income and has thus a considerable redistributive effect. The overall redistributive impact is however difficult to gauge as it depends on how minimum income benefits are combined with other social assistance schemes. For instance, in continental Europe, minimum income programmes often complement other benefits delivering important first-tier safety nets whereas in Australia and New Zealand it represents the main benefit for individuals without income.

\section{Family cash benefits are targeted towards low-income groups}

Family cash benefits have a rather strong redistributive impact. Although they account for a rather small share of total cash transfers in most countries, they tend to be more progressive than other transfers. ${ }^{14}$ In the mid-2000s, the redistributive impact of family cash benefits was the largest in Ireland, followed by the Netherlands, Australia and Austria, but well below the OECD average in the United States, Switzerland, Portugal, Denmark and Norway (Annex 2, Table A2.1). As with other cash benefits, crosscountry variations in the redistributive impact reflect differences in the size and progressivity of such benefits. While the majority of OECD countries implements universal family cash benefits, some rely on income-tested schemes. In addition, child benefits based on the number of children in the household can benefit low-income groups more as these households often have more children, at least in some countries including the United Kingdom (ONS, 2010).

13. Progressivity of unemployment benefits also depends on the type of family (Annex 2, Table A2.4). For instance, unemployment benefits for a family with children are slightly less progressive than transfers to those without. Long-term unemployment benefits and social assistance for people who have been unemployed for five years or more are on average as progressive as those granted during the initial phase of unemployment spells (Annex 2, Table A2.5). But the most progressive countries are not the same.

14. Family cash benefits do not include public spending on services for families with children (e.g. direct financing and subsidising of childcare providers and early education facilities) nor financial support for families provided through the tax system. 
Figure 8. Progressivity of unemployment benefits net of taxes

Measured by the difference in net replacement rates between low and high income earners ${ }^{1}$

2009 , initial phase of unemployment

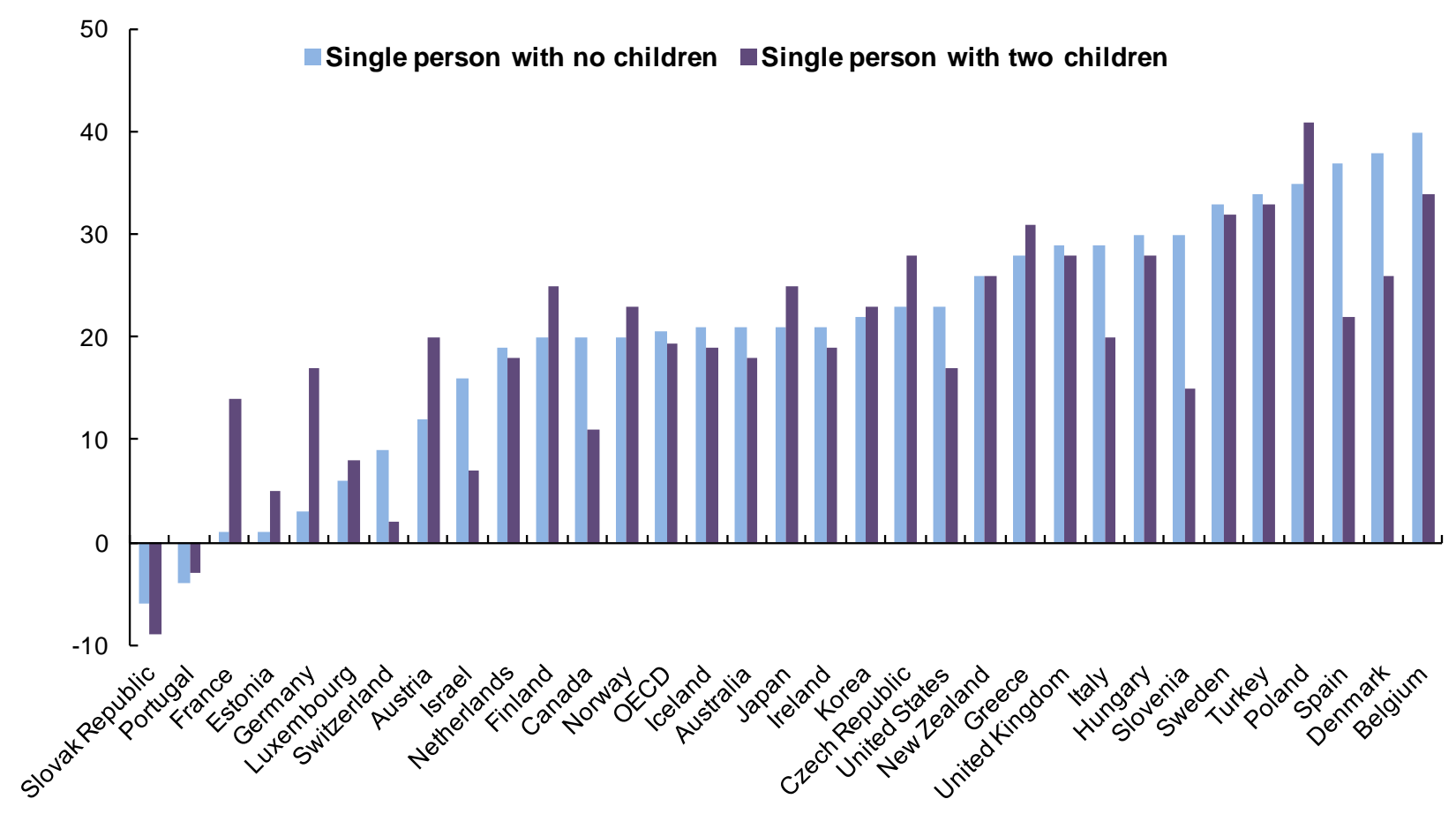

1. Progressivity is defined as the difference in the net replacement rate for low and high earners defined as having earnings equal to 67 and $150 \%$ of the average wage. The larger the difference, the more progressive are unemployment benefits. Countries are ordered from the smallest to the largest values in progressivity for a single person with no children. These replacement rates refer to all unemployment benefits and not only to those insurance-based but no social assistance "top-ups" are included in either the in-work or out-of-work situation. One limitation of this indicator is that it does not take into account the duration of the unemployment spell. In addition, it is based on net replacement rates and thus also reflects the progressivity of personal income taxes (any income taxes payable on unemployment benefits are determined in relation to monthly values, multiplied by 12 , even if the maximum benefit duration is shorter than 12 months). Children are aged 4 and 6 and neither childcare benefits nor childcare costs are considered.

Source: OECD, Tax-Benefit Models, www.oecd.org/els/social/workincentives.

\section{The redistributive impact of taxes: cross-country differences and driving forces}

The overall redistributive impact of taxes depends on the amount of taxes collected (size), the tax mix and the progressivity of each tax. Household surveys are useful as they provide actual tax payments including tax relief. But they exclude social security contributions paid by employers and consumption taxes. In addition, household taxes covered by household surveys vary across countries. This section thus includes additional information to assess the redistributive impact of taxes. 
Figure 9. Change in the progressivity of initial unemployment benefits for a single person

2001 to 2009

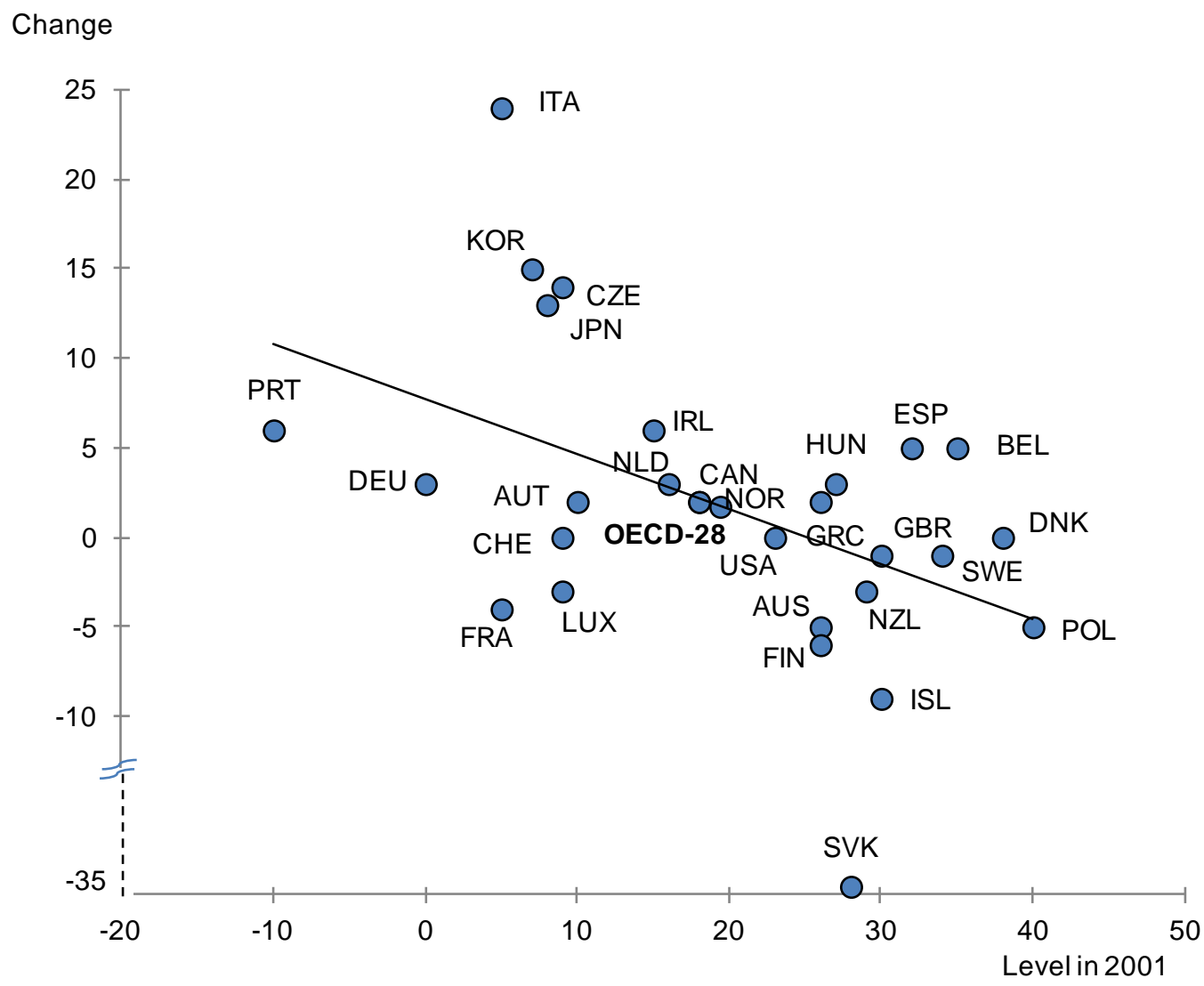

Source: OECD, Tax-Benefit Models, www.oecd.org/els/social/workincentives.

\section{Redistribution via household taxes as gauged by household surveys}

The redistributive impact of taxes can be gauged by the difference in the concentration coefficients for income before and after taxes, as derived from household surveys (Box 3). In the late 2000s, the redistributive impact was the highest in Australia, Denmark, Germany, Israel, Italy and the United States (Figure 10, Panel A). It was by far the lowest in Switzerland, followed by Iceland, Korea and Japan. Some of the countries with the highest inequality in market income tend to redistribute more through household taxes than less unequal countries. Australia, Israel, Italy, the United Kingdom and the United States are examples. Chile, however, clearly stands out, having a wide market income dispersion combined with little redistribution via the tax system. 


\section{Figure 10. The redistributive impact, size and progressivity of household taxes}

In the late 2000s

Panel A: Unequal countries tend to redistribute more through household taxes

Redistributive impact of taxes

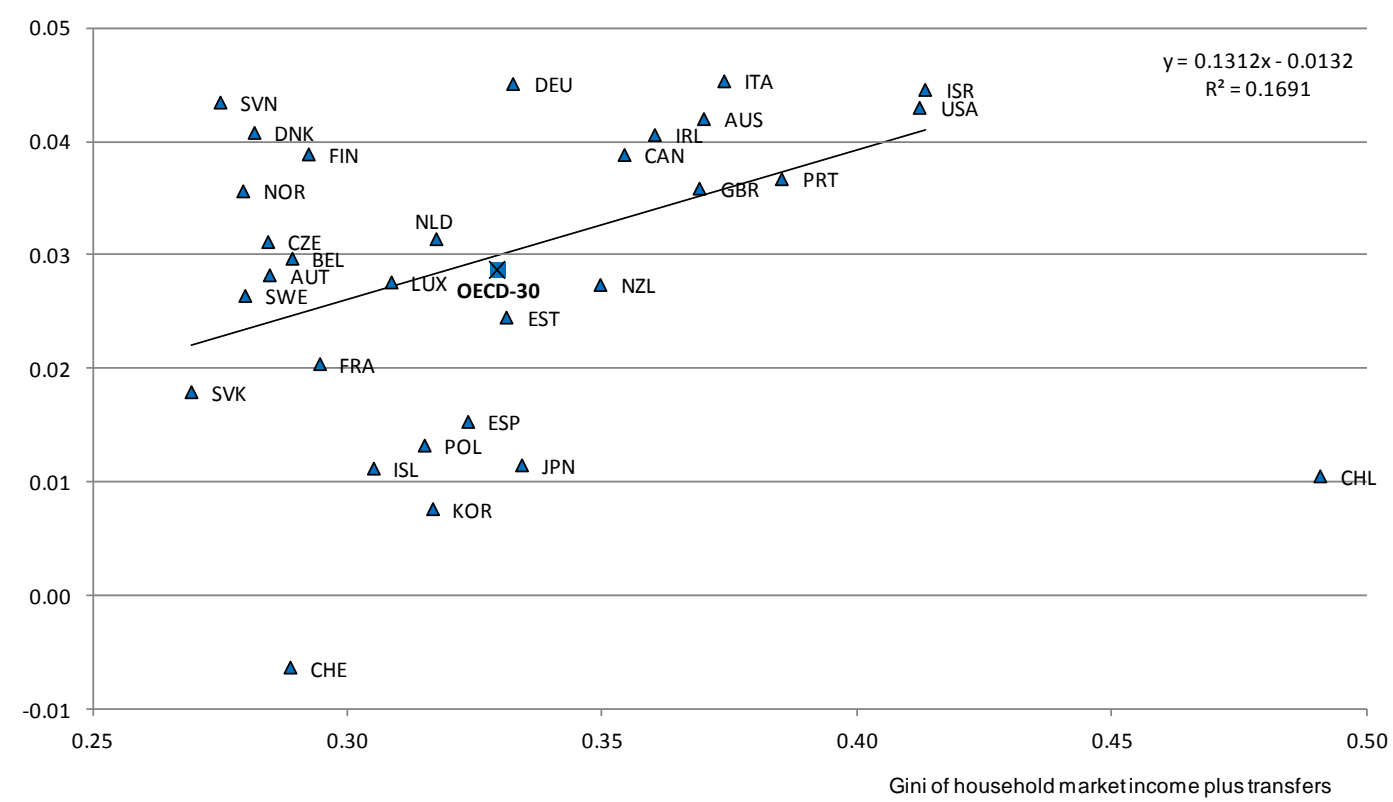

Panel B. High tax countries tend to have less progressive household taxes

Progressivity index of household taxes

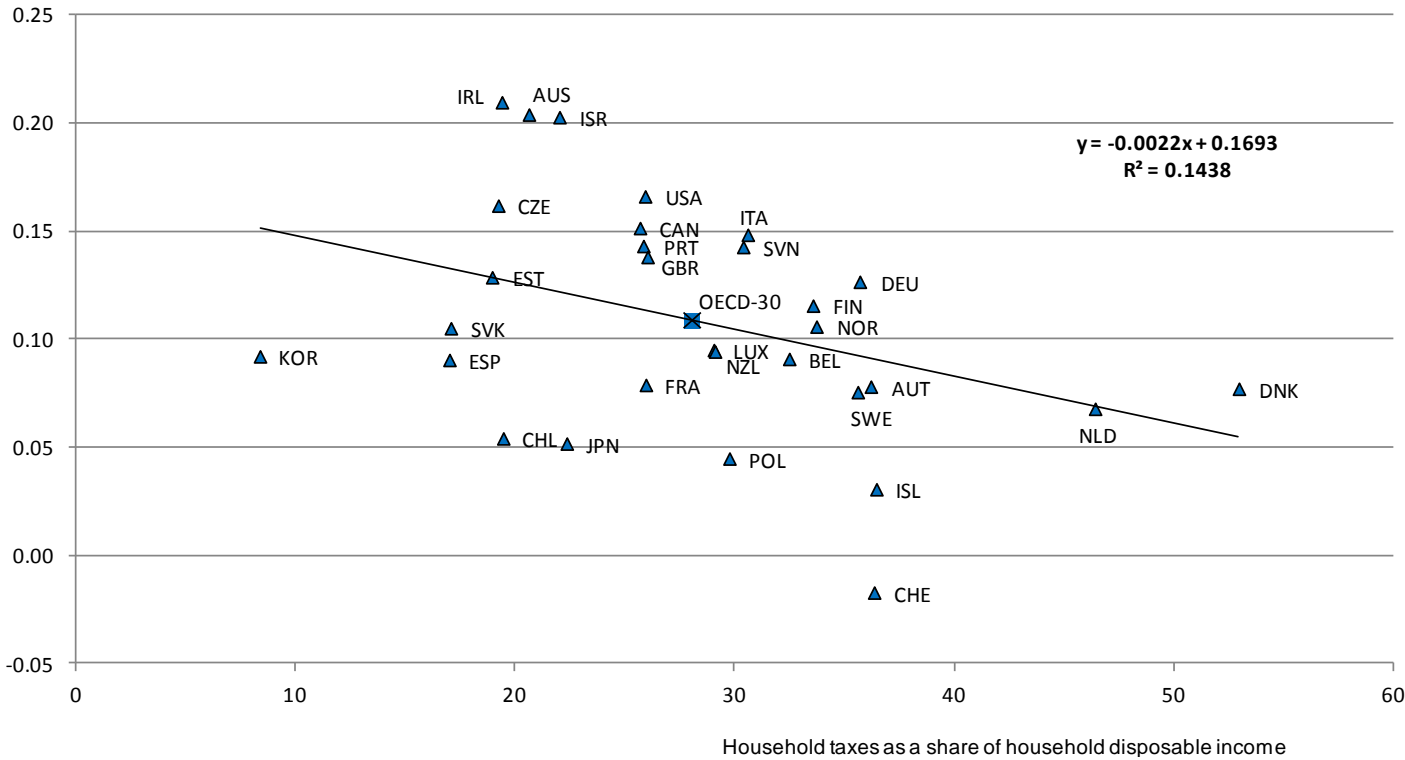

Note: The redistributive impact of household taxes is measured as the difference between the concentration coefficient of income after transfers but before taxes and that of disposable income (i.e. after taxes and transfers). The progressivity index of household taxes is the Kakwani index computed as the concentration coefficient for taxes less the concentration coefficient for income after transfers and before taxes (see Box 3). Data for France and Ireland refer to the mid-2000s. In Panel A, the trend line excludes Chile. Data for Greece, Hungary, Mexico and Turkey are not available.

Source: OECD Income Distribution and Poverty Database. 
The redistributive impact of household taxes depends on both their share in disposable income (i.e. their size) and their progressivity. It varies little across countries despite large cross-country differences in the size of taxes. As an illustration, household taxes absorbed more than $35 \%$ of household disposable income in Austria, Denmark and Sweden in the late 2000s, but their redistributive impact was lower than in Australia, Israel and the United States, all characterised by a much lower tax-to-income ratio. In many high-tax countries, taxes have a relatively low redistributive impact because they embody little progressivity (Figure 10, Panel B) - this is particularly the case in Belgium, Denmark, Iceland and Sweden. And household taxes are more progressive in the United States than in most EU countries. ${ }^{15}$ However, some countries (including Chile, Korea and Japan) combine a relatively low tax burden with very little progressivity.

\section{Going beyond household surveys when assessing the redistributive impact of taxes}

Assessing the redistributive impact of tax systems based on household surveys has serious limitations. The data are available for only a few years, which makes it difficult to assess the impact of tax reforms. Furthermore, most household surveys focus on the personal income tax, social security contributions paid by employees and, sometimes, property taxes. ${ }^{16}$ They do not therefore take into account consumption taxes, employers' social security contributions and corporate income taxes, thus leaving aside more than $50 \%$ of total tax revenues on average across the OECD. This omission creates serious biases since the tax mix varies widely both across countries and over time (Figure 11). In particular, consumption taxes which are often seen as being regressive (see below) - have declined as a share of total tax revenue in most OECD countries. ${ }^{17}$ In 2008 this share ranged from about $15 \%$ in Japan and the United States to over $30 \%$ in Chile, Denmark, Greece and Poland. The rest of this section will go beyond household surveys to assess the redistributive impact of taxes, by relying on statutory tax schedules and actual tax revenues as well as a literature review.

15. Various studies have compared the progressivity of tax systems of European countries with that of the United States (see for instance Prasad and Deng, 2009; Piketty and Saez, 2007; Joumard, 2001). Though they use different definition, methods and databases, they reach the same conclusion: the US tax system is more progressive than that of the continental European countries.

16. In OECD (2008a), the data are drawn from household surveys and household taxes should in principle cover personal income tax, social security contributions paid by employees (but not by employers) and property taxes. In practice, however, the coverage varies from one country to another. And the database does not allow a break-down of these taxes. The coverage also varies significantly across studies. Piketty and Saez (2007) rely on actual tax returns. They include the federal corporate income tax for the United States. Assuming that the incidence of the US federal corporate income tax falls entirely on capital income, they find that the corporate income tax is progressive. With a similar assumption, Roach (2003) reaches the same conclusion but notes that if $25 \%$ of corporate taxes are allocated to consumers and another $25 \%$ to workers, then the progressivity of corporate taxes virtually disappears. Duncan and Sabirianova Peter (2008) focus on the personal income tax only. Fuest et al. (2010) assess the redistributive impact of personal income taxes and social security contributions paid by both employees and employers.

17. Between 1975 and 2008, the share of consumption taxes in total tax revenues dropped from 26 to $22 \%$ in Canada, from 32 to 24\% in France and from 17 to $14 \%$ in the United States. 
Figure 11. Tax revenues: level, composition and change over time

OECD (1)

$\begin{array}{lll}\text { 口Personal income tax } & \text { 口Consumption taxes } & \text { वProperty taxes } \\ \text { ロCorporate income tax } & \text { 口SS \& payroll taxes (2) } & \text { वOther }\end{array}$

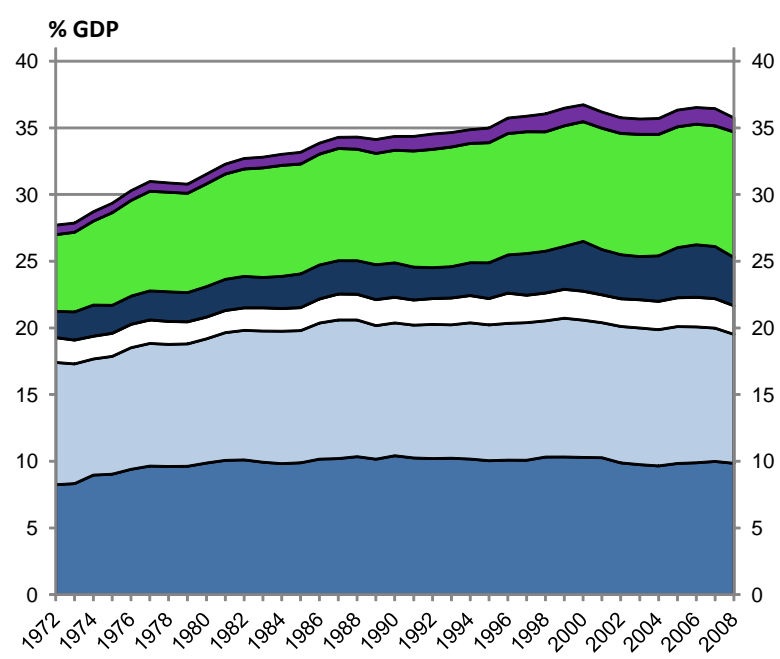

Japan

口Personal income tax 口Consumption taxes aProperty taxes

- Corporate income tax aSS \& payroll taxes (2) घOther

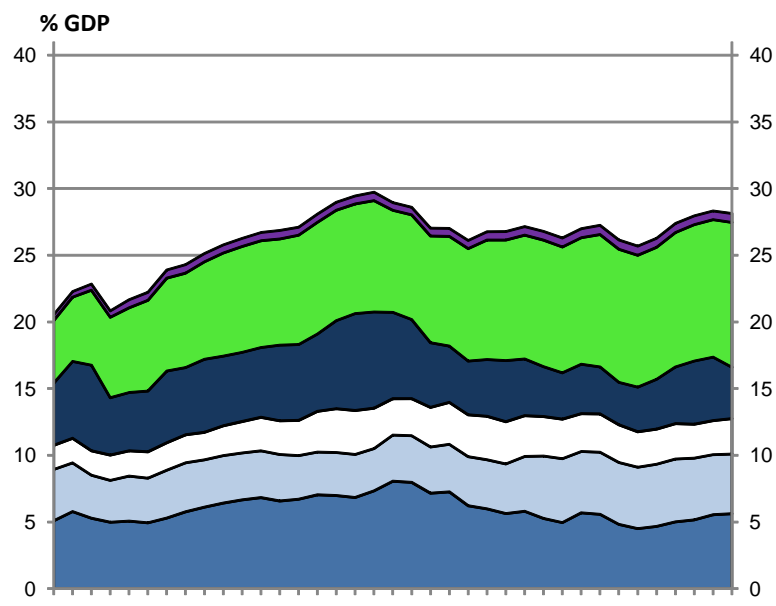

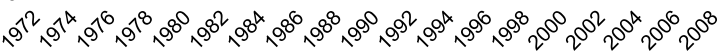

United States

口Personal income tax $\quad$ वConsumption taxes $\quad$ PProperty taxes

-Corporate income tax 口SS \& payroll taxes (2) $\quad$ aOther

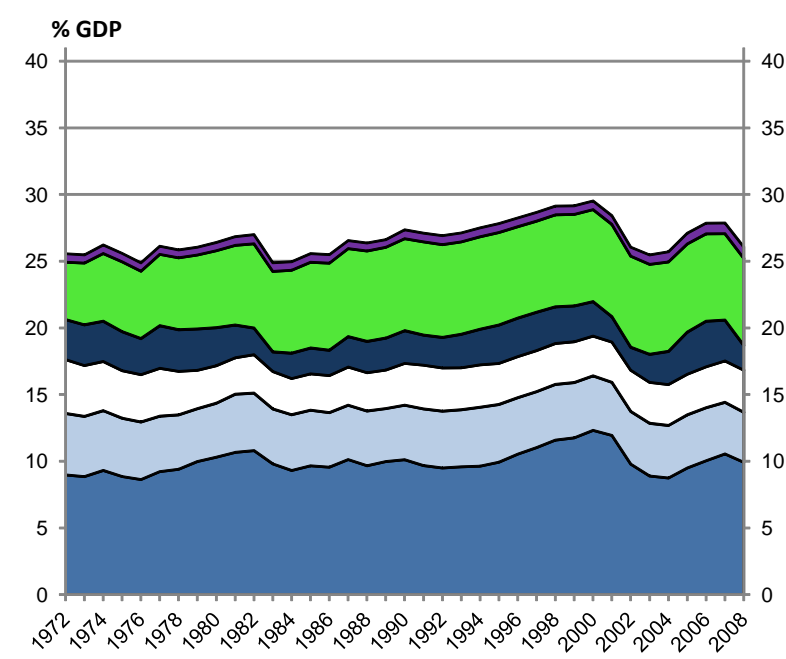

European Union (3)

口Personal income tax

-Corporate income tax

Consumption taxes

口SS \& payroll taxes (2) घOther

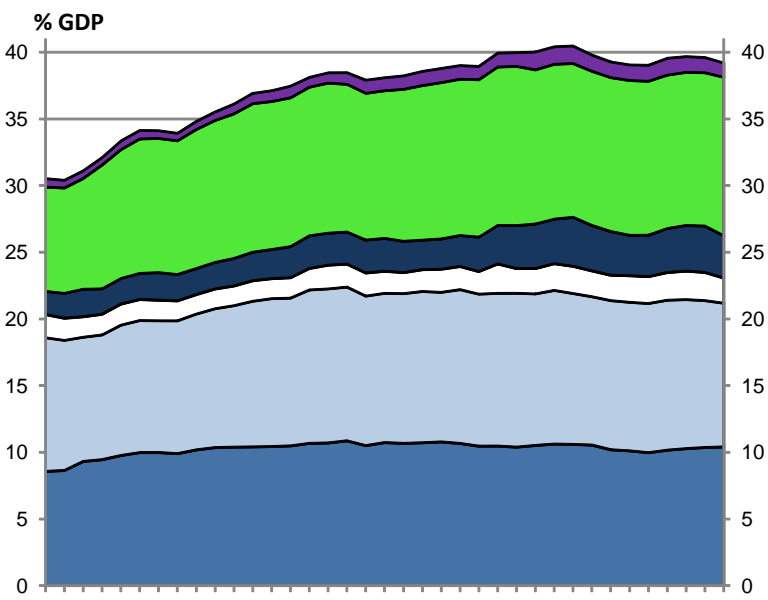

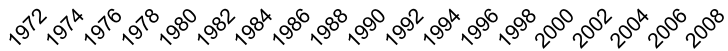

1. Unweighted average excluding Chile, the Czech Republic, Estonia, Hungary, Israel, Mexico, Poland, the Slovak Republic and Slovenia.

2. Social security contributions paid by employees and employers.

3. Unweighted average excluding the Czech Republic, Estonia, Hungary, Poland, the Slovak Republic and Slovenia.

Source: OECD (2010c), Revenue Statistics. 


\section{Labour income taxes: progressivity indicators based on statutory tax schedules}

The progressivity of tax systems can also be measured by statutory tax schedules. Compared with those derived from household surveys, such measures have the main advantage of being unaffected by cross-country differences in the definition of household taxes and by differences in responding to household surveys. The OECD has built synthetic indicators of labour income tax progressivity, based on statutory tax schedules, over a wide income range. ${ }^{18}$ Focusing on a single wage earner, Figure 12 (Panel A) shows that there is wide cross-country variation in the degree of progressivity of statutory schedules for personal income taxes and employees' social security contributions.

Also interesting are the differences in the progressivity structure along the income ladder. Progressivity at the higher end of the income distribution - i.e. income equal to $167 \%$ the average wage is strongest in Ireland, Sweden and Denmark. At the lower end of the income distribution - i.e. income equal to $67 \%$ of the average wage -, tax schedule progressivity is highest in Hungary, Luxembourg and Belgium. The US tax schedule has slightly more progressivity at the upper end but its overall progressivity is below the OECD average - at least for single wage earners - while Japan and Korea have very little progressivity embedded in their tax schedule for labour income. ${ }^{19}$

\section{Despite cuts in top marginal rates, labour taxes have often become more progressive}

Statutory tax schedules can also be used to assess changes in progressivity over time. Personal income tax schedules have generally become flatter over the past decades (Piketty and Saez, 2007; Sabirianova Peter et al., 2008). Top marginal rates have declined in the vast majority of the OECD countries since 2000, by more than 10 percentage points in Belgium, the Czech Republic, France, Mexico and the Slovak Republic (Table 1). In addition, the income thresholds from which these top marginal rates apply have been raised in some countries including Australia, Canada, Germany and the United States. Finally, cross-country variation in top rate thresholds is wide: the top rate applies to those earning the average wage in Denmark while in the United States, it applies only to those earning about 10 times the average wage.

18. Taxes on labour income consist of personal income taxes, social security contributions paid by employees as well as payroll taxes when relevant. The calculation and coverage of progressivity indices based on tax schedules differ from the Kakwani index presented above. In particular, they include standard cash (mostly family-related) transfers and do not account for non-standard tax reliefs, such as those associated with mortgage interest payments. Drawing international comparisons for single taxpayers without children allows leaving aside most cash transfers to focus mostly on taxes. The correlation between the progressivity index based on tax schedules (for single taxpayers and under the assumption of a similar distribution of income across countries) and the Kakwani progressivity index based on household surveys is 0.58 , significant at $5 \%$.

19. Due to the various tax reliefs for low-income earners with children, the US personal income tax is much more progressive for families with children than for single tax payers. 
Figure 12. Progressivity of statutory personal income tax and employee social security contribution schedules Based on statutory tax schedules for single tax payers without children

Net personal tax progressivity, synthetic indicator

-Progressivity at the lower end of the income distribution, right scale

$\Delta$ Progressivity at the higher end of the income distribution, right scale

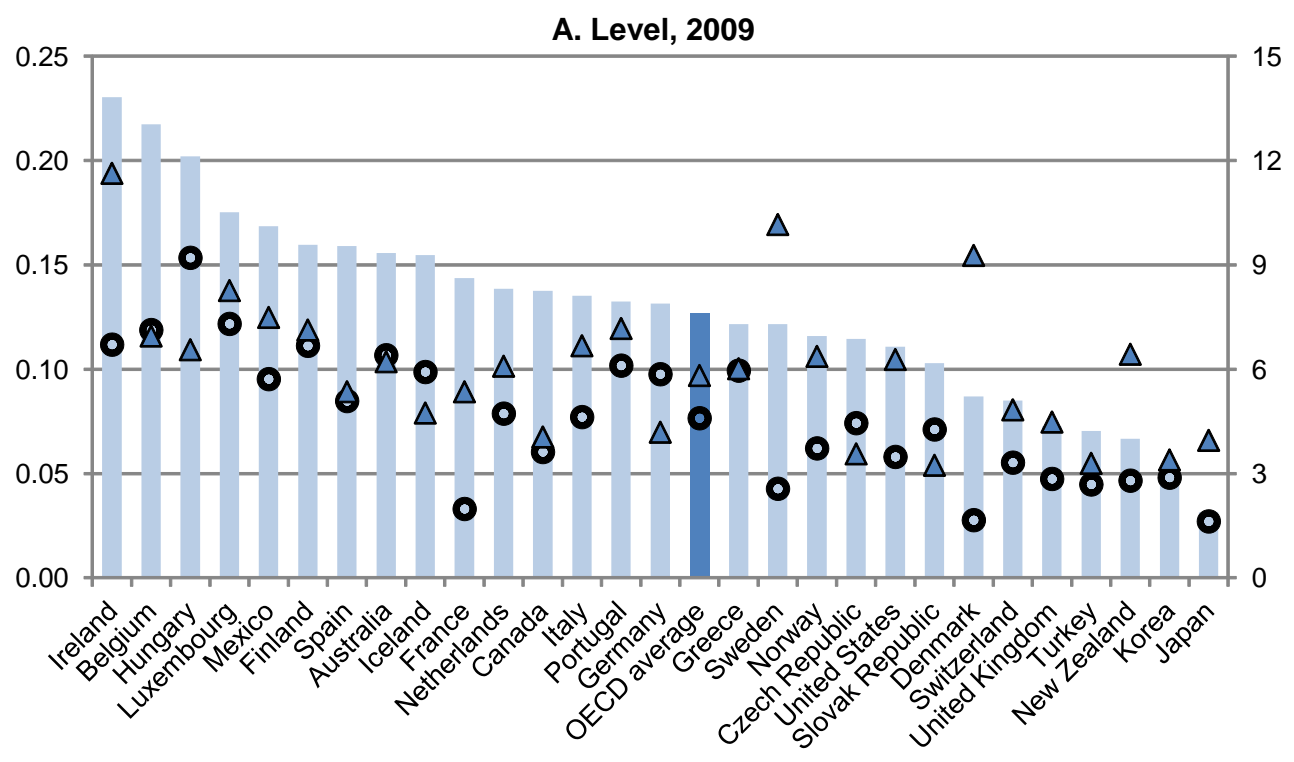

\section{B. Change over the period 2000-2009}

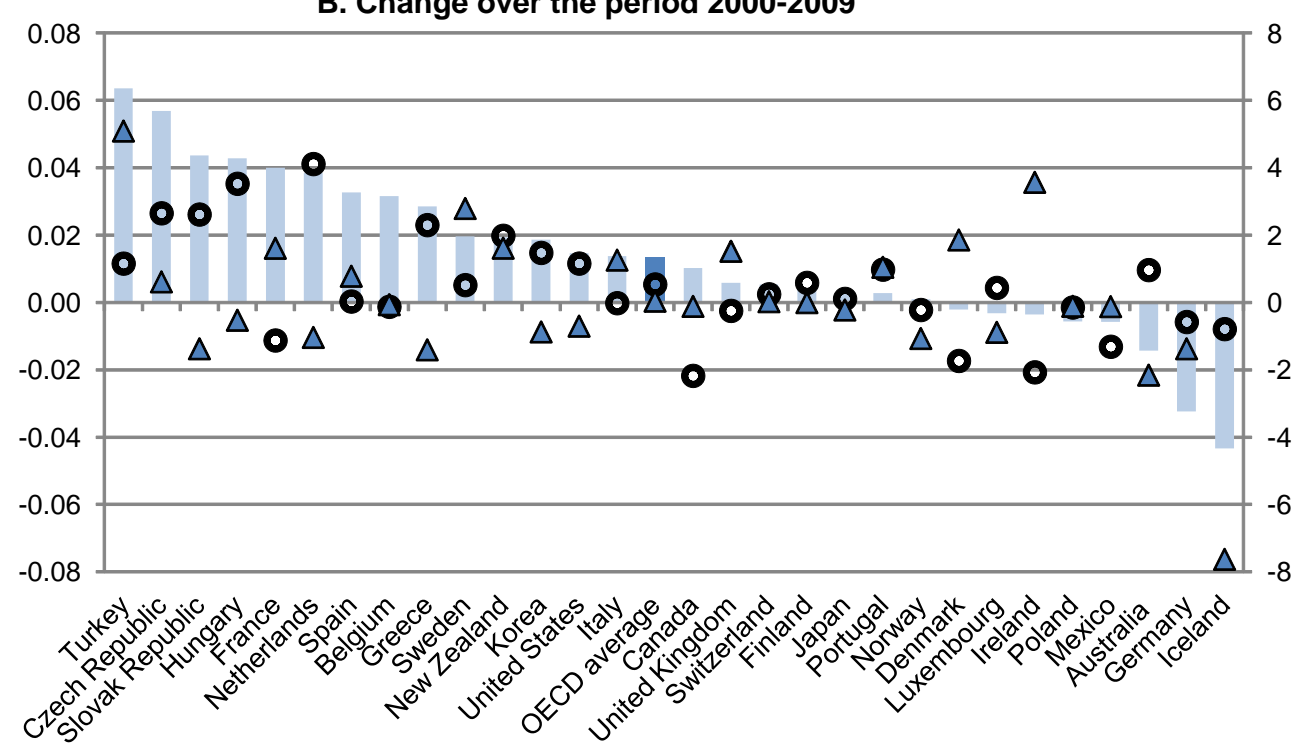

Note: Net personal income tax is defined as the sum of personal income tax and employee social security contributions net of standard cash transfers. Standard tax relief measures - including those linked to marital and family status and income level are accounted for. Non-standard tax relief measures, i.e. those determined by reference to actual expenses incurred (such as the amount of interest paid on loans), are not included. The synthetic indicator for net personal tax progressivity presented here is not a Kakwani index. It is calculated as the difference between the average net personal tax rate at two income levels based on the assumption of a similar income dispersion across OECD countries. This difference is then divided by the change in income level. Progressivity at the lower end (respectively higher end) of the income distribution is computed as the difference in personal income tax rates (personal income tax and employee social security contributions expressed as a per cent of gross wage earnings) between the average wage and $67 \%$ of the average wage (respectively between $167 \%$ of the average wage and the average wage).

Source: OECD (2008b), Taxing Wages 2008-2009 and OECD estimates. 
ECO/WKP(2012)3

Table 1. Top personal income tax rates and thresholds

\begin{tabular}{|c|c|c|c|c|c|c|}
\hline & \multicolumn{3}{|c|}{ Top statutory income tax rate $(\%)^{1}$} & \multicolumn{3}{|c|}{ Threshold (multiple of the average wage) ${ }^{2}$} \\
\hline & 2000 & 2009 & $\begin{array}{c}\text { Change } \\
2000 \text { to } 2009 \\
\end{array}$ & 2000 & 2009 & $\begin{array}{c}\text { Change } \\
2000 \text { to } 2009\end{array}$ \\
\hline $\begin{array}{l}\text { Australia } \\
\text { Austria }\end{array}$ & $\begin{array}{l}48.5 \\
50.0\end{array}$ & $\begin{array}{l}46.5 \\
50.0\end{array}$ & $\begin{array}{r}-2.0 \\
0.0\end{array}$ & $\begin{array}{l}1.2 \\
2.3\end{array}$ & $\begin{array}{l}2.8 \\
2.1\end{array}$ & $\begin{array}{r}1.6 \\
-0.2\end{array}$ \\
\hline Belgium & 63.9 & 53.7 & -10.2 & 1.2 & 1.1 & -0.1 \\
\hline Canada & 46.4 & 46.4 & 0.0 & 1.7 & 2.9 & 1.2 \\
\hline Czech Republic & 32.0 & 15.0 & -17.0 & 2.4 & 0.4 & -2.0 \\
\hline Denmark & 59.7 & 51.6 & -8.1 & 1.0 & 1.0 & 0.0 \\
\hline Finland & 55.2 & 49.1 & -6.1 & 2.1 & 1.8 & -0.3 \\
\hline France & 58.3 & 47.8 & -10.5 & 2.9 & 2.8 & -0.1 \\
\hline Germany & 53.8 & 47.5 & -6.3 & 1.7 & 6.2 & 4.5 \\
\hline Greece & 45.0 & 40.0 & -5.0 & 3.8 & 3.6 & -0.2 \\
\hline Hungary & 40.0 & 36.0 & -4.0 & 0.9 & 0.8 & -0.1 \\
\hline Iceland & 45.4 & 37.2 & -8.2 & 1.5 & 0.3 & -1.2 \\
\hline Ireland & 44.0 & 41.0 & -3.0 & 1.0 & 0.9 & -0.1 \\
\hline Italy & 46.4 & 44.9 & -1.5 & 3.9 & 3.2 & -0.7 \\
\hline Japan & 50.0 & 50.0 & 0.0 & 4.5 & 4.6 & 0.1 \\
\hline Korea & 44.0 & 38.5 & -5.5 & 5.5 & 3.2 & -2.3 \\
\hline Luxembourg & 47.2 & 38.9 & -8.3 & 2.1 & 1.0 & -1.1 \\
\hline Mexico 3 & 40.0 & 28.0 & -12.0 & 49.3 & 4.7 & -44.6 \\
\hline Netherlands & 60.0 & 52.0 & -8.0 & 1.6 & 1.2 & -0.4 \\
\hline New Zealand & 39.0 & 38.0 & -1.0 & 1.7 & 1.5 & -0.2 \\
\hline Norway & 47.5 & 40.0 & -7.5 & 2.6 & 1.6 & -1.0 \\
\hline Poland & 40.0 & 32.0 & -8.0 & 3.3 & 2.8 & -0.5 \\
\hline Portugal & 40.0 & 42.0 & 2.0 & 3.4 & 4.3 & 0.9 \\
\hline Slovak Republic & 35.0 & 19.0 & -16.0 & 3.2 & 0.5 & -2.7 \\
\hline Spain & 48.0 & 43.0 & -5.0 & 4.4 & 2.4 & -2.0 \\
\hline Sweden & 55.4 & 56.5 & 1.1 & 1.5 & 1.5 & 0.0 \\
\hline Switzerland & 43.2 & 41.7 & -1.6 & 4.0 & 3.6 & -0.4 \\
\hline Turkey & 35.6 & 35.6 & 0.0 & 8.1 & 3.0 & -5.1 \\
\hline United Kingdom & 40.0 & 40.0 & 0.0 & 1.4 & 1.3 & -0.1 \\
\hline United States & 46.7 & 41.9 & -4.8 & 8.9 & 9.6 & 0.7 \\
\hline OECD average & 46.7 & 41.5 & -5.2 & 2.9 & 2.5 & -0.4 \\
\hline Standard deviation & 7.9 & 9.3 & 1.5 & 2.0 & 2.0 & 0.0 \\
\hline
\end{tabular}

1. These are the top statutory tax rates (combined central and sub-central) that apply from the threshold levels reported in the fourth and fifth columns.

2. These columns report the level of gross wage earnings (expressed as a multiple of the average wage) at which the top personal income tax rate starts to apply. The average and dispersion exclude Mexico.

3. The threshold figure for Mexico in 2000 reflects a tax schedule with two supplementary brackets designed to tax very high earners more heavily. These supplementary brackets were removed in 2002, resulting in the threshold of the upper bracket coming down sharply as a proportion of average earnings.

Source: OECD (2009), OECD Tax Database.

Despite cuts in top rates, tax schedule progressivity has increased in a majority of OECD countries since 2000, largely driven by changes at the lower end of the income distribution (Figure 12, Panel B). To make work more attractive for spouses and low-paid workers, many countries (including Belgium, Canada, Finland, France, the Netherlands, the Slovak Republic, Sweden, the United Kingdom and the United States) have introduced or strengthened in-work benefits targeted at low-income groups, thereby incidentally increasing the progressivity of the personal income tax. Several countries (including Austria, 
Finland, Germany, Italy and the Slovak Republic) have also raised the tax-free allowance ${ }^{20}$ or made social security contributions less regressive by removing or raising social security contribution caps or floors (for instance, France and the United States). ${ }^{21}$ In parallel, partial or total exemptions for social security contributions below a given income threshold have been introduced or made more generous in some European countries (including Austria, Belgium, France, Spain and the United Kingdom) to reduce the cost of labour for low-paid workers.

\section{The progressivity of the personal income tax is often hollowed out by tax expenditures}

The use of tax expenditures has been growing in many OECD countries (OECD, 2010e) and their value tends to increase with income. With the main exception of earned-income tax credits targeted at low income groups, the value of tax reliefs often increases for higher tax brackets, because the income or transaction targeted is most commonly used by higher-income individuals. ${ }^{22}$ Tax breaks for health and child care, education, owner-occupied housing and retirement savings often fall into this category. Regarding the latter, Antolin et al. (2004) confirm that in Canada, the United Kingdom and the United States voluntary tax-favoured retirement schemes benefit disproportionately upper income individuals. Overall, tax expenditure can thus reduce the progressivity of the personal income tax significantly. Landais et al. (2011) further show that, in France, tax expenditures result in a decline of the effective personal income tax rate beyond an income threshold.

Only the United States provides much information on who benefits from tax expenditures. There, tax expenditures pertaining to the personal income tax clearly raise after-tax incomes more for higher-income than lower-income taxpayers (Burman et al., 2008). More than $90 \%$ of the savings from preferential tax rates on long-term capital gains and qualified dividends go to taxpayers in the top quintile of the income distribution, and nearly half of the benefits go to people in the top $0.1 \%$ (Williams, 2011). Concerning health care related tax expenditure (1.3\% of GDP), Toder et al. (2009) estimated that more than $40 \%$ of the implicit subsidy accrues to the $20 \%$ richest households. Likewise, almost $70 \%$ of the implicit subsidy associated with the deductibility of mortgage interest on owner-occupied homes benefits the top income quintile. $^{23}$

20. The Slovak Republic replaced the progressive personal income tax system by a flat rate system in 2004 . However, the basic tax allowance, which declines as income grows, and the refundable tax credit targeted at low-income earners introduced in 2009 reinforce tax progressivity significantly at the lower end of the income distribution.

21. In Denmark, Hungary, Spain and Switzerland, minimum amounts of social security contributions - floors still have to be paid by employees and/or employers. Caps are in place in many OECD countries.

22. Tax reliefs take different forms, including: $i$ ) tax allowances and exemptions (amounts are deducted/excluded from the tax base); $i$ ) rate relief (a reduced rate of tax applied to a group of taxpayers or transactions); iii) tax deferral (a delay in paying the tax) and; $i v$ ) tax credits (amounts deducted from tax liabilities). Standard tax reliefs - including those linked to marital and family status and income - are accounted for in the data on progressivity of personal income taxes and employee social security contributions from Taxing Wages. Thus, EITC type tax reliefs are included. Non-standard tax reliefs, i.e. reliefs determined by actual expenses incurred (such as the amount of interest paid on loans), are not included.

23. Matsaganis and Flevotomou (2007) used the tax-benefit model EUROMOD to quantify the distributional impact of mortgage interest tax relief in the Netherlands, Sweden, Finland, Italy and Greece. They show that higher-income groups capture a disproportionate share of mortgage interest tax relief in all these countries. The effect is most regressive in the Netherlands and least regressive in Sweden. 


\section{Taxes on capital income have been reduced and are often lower than taxes on labour income}

Various savings schemes have long been granted a preferential tax treatment in most OECD countries. Since capital income tends to be concentrated in upper income brackets, such tax relief implies less progressivity of the income tax. Governments promote private pensions by means of tax incentives in most OECD countries. In the most common regime, private pension savings can be deducted from the income tax base and accrued return on investment is exempt from taxation, but pension benefits arising from these savings are taxed (Yoo and de Serres, 2004). Housing investment also often benefits from a favourable tax treatment with imputed income from owner-occupied dwellings and capital gains on the sale of a principal residence taxed less than other capital income, or not taxed at all, while interest payments on debt-financed investment in owner-occupied housing are sometimes deductible from taxable personal income. These taxfavoured schemes, however, tend to affect the mix, rather than the volume, of private savings. They may thus divert saving and investment away from other activities that may be more conducive to growth.

The low taxation, if any, of capital gains on shares also has important distributional consequences, though its impact on growth is subject to debate. It is often argued that a lower tax rate on capital gains encourages risk-taking and entrepreneurship, thus promoting growth, while high capital gains taxes create an inefficient "lock-in" effect. Burman and Moynihan (2011) show that 94\% of the value of capital gains tax breaks in the United States benefit the top quintile. They consider that, since capital losses are often supported by the government (in the form of reduced taxes), capital gains should be taxed. They also argue that the lock-in effect is small. Because it is often difficult to distinguish between labour and capital income, in particular for the self-employed, low taxation of capital income further creates opportunities for income-shifting and tax planning (Diamond and Saez, 2011). And it may ultimately favour top income groups most (top executives, finance professionals and entrepreneurs), who can benefit from carried interest arrangements and the low taxation of stock options (OECD, 2011a). ${ }^{24}$

Some countries have moved further towards a non-progressive and reduced taxation of most capital income, in particular in Europe. The main objective of such reform is to reduce tax distortions across savings instruments and incentives for capital exports. Precursors were the Nordic countries which adopted a dual income tax system in the late 1980s or early 1990s. Under such a system, a unique flat tax rate applies to net capital income (interest income, dividends and capital gains) while labour income is subject to a progressive tax schedule. Many countries have not adopted a "pure" dual income tax system but they increasingly tax interest income at flat rates, usually lower than the marginal rates which apply on labour income (Joumard, 2001). In contrast, several countries have continued to tax most types of capital income as labour income, i.e. at progressive rates, including Canada, Ireland, Korea, Luxembourg, Switzerland, Turkey, the United Kingdom and the United States (OECD, 2006).

\section{Property taxes play a minor role in many OECD countries}

Raising property taxes is often presented as one option to increase the redistributive impact of tax systems. Property taxes amount to more than $10 \%$ of total tax receipts in several OECD countries and about $2 \%$ of GDP on average across the OECD. As a share of GDP, they are highest in the United Kingdom, Canada, France and the United States, and lowest in several continental European countries and Mexico (Figure 13). Recurrent taxes on immovable property account for the bulk in most countries though taxes on financial and capital transactions play a dominant role in Belgium, Greece, Korea, Italy and Turkey.

24. Individuals may benefit from "carried interest" arrangements when they have a relatively small equity stake in a business. If successful, rewards are taxed as capital gains, hence at a rate that is generally below their marginal personal income tax rate. 
Figure 13. The property tax take varies significantly across OECD countries

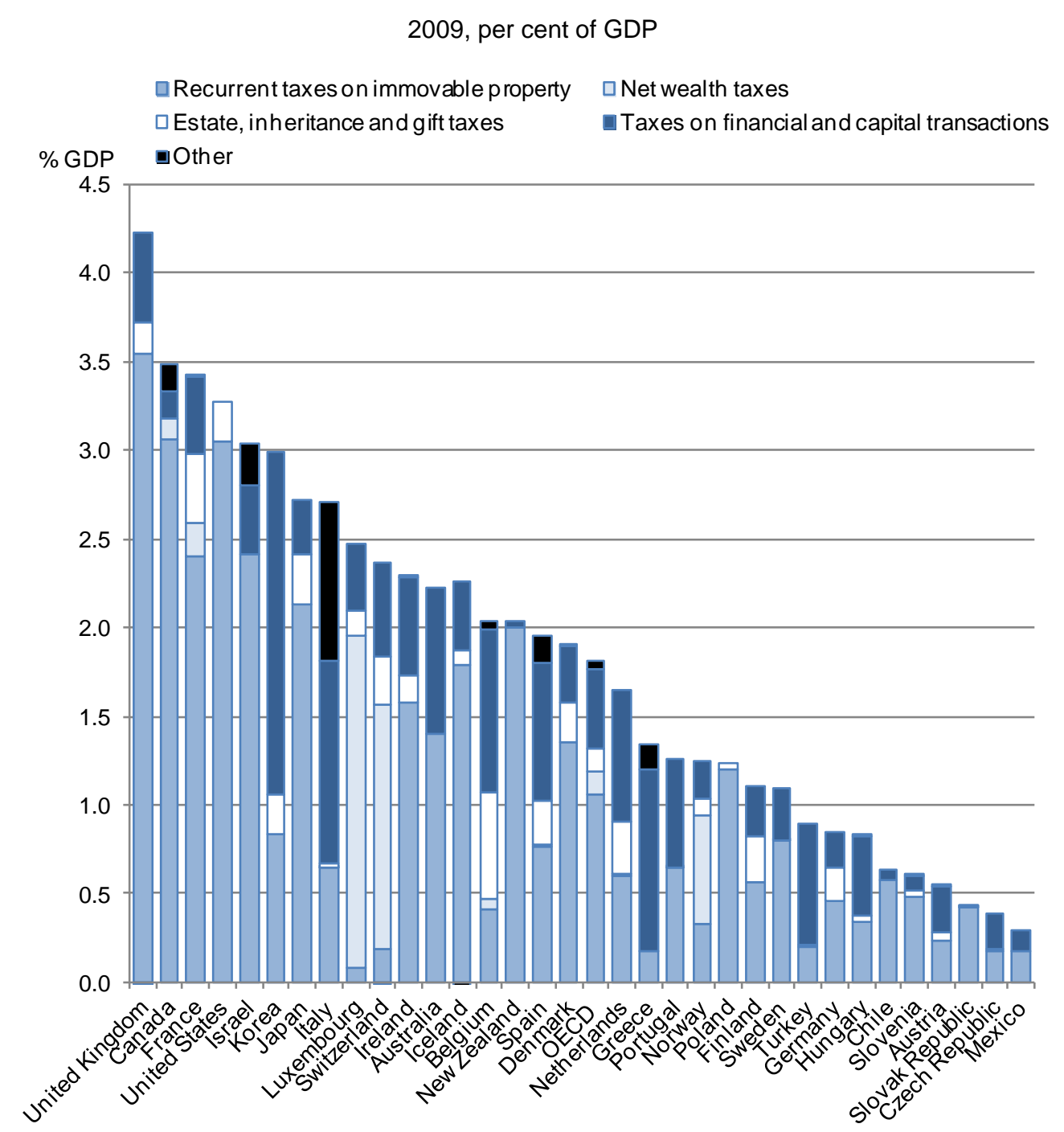

Source: OECD (2010c), Revenue Statistics 2010.

\section{Real-estate taxes are regressive in some countries}

While high-income households pay more recurrent taxes on immovable property in absolute terms, real estate taxes often absorb a larger share of the income of the poorer households. In the United Kingdom, for instance, the Council Tax amounts to $6 \%$ of income for those in the bottom fifth, but only $2 \%$ for those in the top fifth (ONS, 2010). A similar pattern is found in Canada (Chawla and Wannel, 2003) and in the United States (Davies et al., 2009). One explanation is that recurrent taxes on immovable property are often a sub-national government tax whose amount should reflect the benefit of local public services (waste collection, etc.) which does not increase much with income. In some countries, real estate taxes are also paid by renters, who often have low income. Part of the regressive nature of real estate taxes may also reflect the fact that many pensioners own expensive houses but receive relatively little income. Still, Palameta and Macredie (2005) found that this is only part of the story in Canada, since non-seniors make up the majority of lower-income homeowners. 
Some countries have introduced tax allowances, income-conditional exemptions or progressive tax rates, to reduce real estate tax payments on low-income groups. For instance, regressivity is mitigated in some US states by a flat dollar amount exemption - e.g. homestead exemptions - or a tax credit designed to assist low-income taxpayers. Similar tax relief is provided by some Canadian provinces and municipalities. And in France, generous income- and family-related tax relief has succeeded in making the largest recurrent tax on immovable property (Taxe d'habitation) slightly progressive since 2000 (Conseil des Prélèvements Obligatoires, 2011; Marical, 2009) at least for the first part of the income distribution. ${ }^{25}$

\section{Wealth, inheritance and gift taxes have been reduced in many countries}

Taxing household wealth, either annually or at the time of transfer (gift and inheritance), is attractive for various reasons. First, the tax base is large and had grown briskly prior to the crisis. As an illustration, households' net worth in France is five times higher than GDP and it has grown by over 7\% on average per year and in real terms between 1997 and 2007, compared to a 1.7\% increase for GDP (Conseil des Prélèvements Obligatoires, 2011). Taxing wealth at a rather low rate should thus generate large and rising tax revenues. Second, real estate accounts for a large share of household net worth (Fredriksen, 2012) and the tax can thus hardly be avoided. Third, inheritance and gift taxes, not only on immovable property but on all net assets, could offer an alternative to the taxation of lifelong saving. It can be considered as a way of taxing, for example, income or capital gains that were tax-exempt during a person's lifetime. Inheritance taxes have the advantage of generating less distortions than annual wealth taxes because inheritance is difficult to plan. Several countries, including the United States, have made inheritance and gift taxes highly progressive by providing tax-free allowances and by applying progressive rates. ${ }^{26}$ Fourth, wealth is more concentrated than income and is becoming more unequally distributed. In the seven OECD countries covered by the Luxembourg Wealth Study, the 10\% richest households hold between 40\% (Italy) and 70\% (United States) of total wealth. And the value of inheritances and gifts as a share of GDP has grown rapidly in some countries - it has risen three-fold since 1950 to reach almost $15 \%$ in 2008 in France (Piketty, 2010) - perpetuating income inequality.

In practice, however, the use of wealth and inheritance taxes has declined. Wealth taxes have been abolished in about a third of the OECD countries since the mid-1990s and several countries (including the United Kingdom) never had this type of tax. ${ }^{27}$ In 2010, only four OECD countries (Canada, France, Norway and Switzerland) still imposed wealth taxes (Price and Dang, 2011). Inheritance and gift taxes are applied rather widely but several countries have reduced or abolished them since the mid-1990s (including Austria, France, New Zealand, Portugal, Slovak Republic and Sweden). The risk of wealth/capital flight to low-tax countries, as well as administrative and collection costs, have often been cited as the main reasons for the limited use of wealth taxes. ${ }^{28}$ It could also be argued that wealth and inheritance taxes entail a double taxation of immovable property, since real estate taxes may already be high, while financial wealth

25. The Conseil des Prélèvements Obligatoires (2011) also notes that existing taxes on real estate transactions - Droits de mutation à titre onéreux - are regressive as they are calculated as the sum of a fixed amount and a percentage of the value of the transaction. The effective tax rate on small transactions is de facto much higher and often paid by low-income families.

26. Roach (2003) shows that the US estate and gift taxes were the most progressive element of federal taxation because they applied only to large estates/gifts and because rates were progressive.

27. Among the countries that reduced or abolished wealth taxes since the mid-1990s, some have increased the taxation of top incomes (Germany) or capital income (Luxembourg and the Netherlands). Spain introduced a wealth tax in September 2011.

28. In France, about 5000 individuals paying the wealth tax (ISF) left the country between 1996 and 2005 (Conseil des Prélèvements Obligatoires, 2011). 
is too mobile to be taxed. However, real estate taxes often finance local services that benefit local populations and businesses. The double-taxation argument has thus a weak basis.

\section{Consumption taxes tend to be regressive}

Consumption taxes account for a significant revenue share in all OECD countries (about 27\% on average) and tend to decline as a share of household disposable income since lower-income households tend to consume a larger share of their income (Prasad and Deng, 2009; Roach, 2003; Warren, 2008). As an illustration, in the United Kingdom, indirect taxes amounted to $13 \%$ of household gross income in 2008 (defined as market income plus cash benefits) but to over 25\% for the lowest quintile and less than $10 \%$ for the top quintile (ONS, 2010). ${ }^{29}$ Likewise, in the United States, sales and excise taxes levied by states are found to be highly regressive. Poor families pay almost eight times more as a share of their income than the best-off families (Davies et al., 2009). It should be noted, however, that calculations based on annual income data may overstate the regressive nature of consumption taxes since consumption largely depends on lifetime income which is less variable than annual household income (Poterba, 1989). In particular, pensioners with low annual income may consume out of their previous (accumulated) earnings.

A lack of data makes it difficult to investigate the redistributive impact of consumption taxes in a cross-country setting. Implicit consumption tax rates can, however, be used to derive estimates (OECD , 2008b). They suggest that the regressive impact of consumption taxes - as measured by the difference in the implicit consumption tax rate for those at $167 \%$ of average earnings and those at $67 \%$ - is higher in the European countries than in the other OECD countries, due to higher consumption tax rates (Figure 14) ${ }^{30}$ Warren (2008) also found a higher regressivity of consumption taxes - measured as the contribution to the Gini coefficient - in Denmark, Finland, Hungary, Norway and Sweden and the lowest regressivity in Japan and the United States. Thus, omitting consumption taxes affects estimates of redistribution achieved through the tax and transfer system and how they differ across countries and evolve over time.

29. In cash terms, the top fifth of households pay three times as much indirect tax as the bottom fifth. This simply reflects higher expenditure by higher income households. The only indirect taxes where average payments in absolute terms do not vary much across the income distribution are those on tobacco, television licences and the tax element of the National Lottery.

30. Reflecting differences in the level of consumption taxes (standard rates at 5\% in Japan and about $7 \%$ in the United States, but up to $25 \%$ for the standard VAT rate in the Nordic countries), Garfinkel et al. (2006) noted that the same hypothetical USD 1000 cash transfer to low-income households buys more goods in the United States and Japan than in the Nordic countries - more than USD 930 compared with USD 750. Adema and Ladaique (2009) also recognise that consumption taxes reduce the real value of consumption which can be financed out of a given level of benefits. Furthermore, they note that, in some countries, policy explicitly took into account the impact of indirect taxation on the financial position of low-income households. For example, when the Goods and Services Tax was introduced in Australia in July 2000 at a rate of $10 \%$ (with food being exempt), a compensation package for social protection benefit recipients was introduced at the same time. 
Figure 14. Average consumption tax rate at different income levels

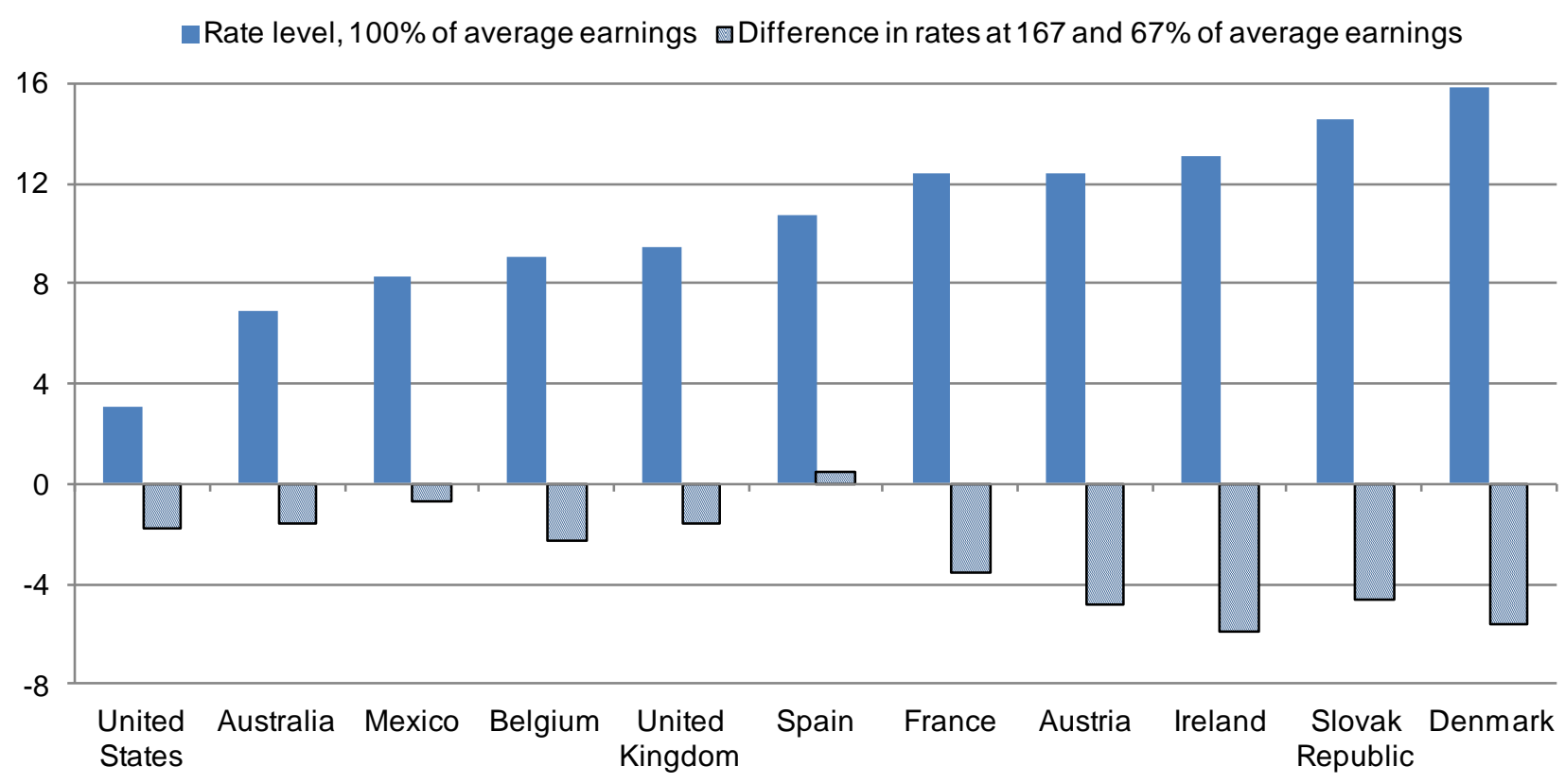

Note: Average consumption tax rates are estimated by using microdata on consumption patterns available from household budget surveys and the corresponding tax rates (VAT, sales taxes and excise duties) in order to calculate the tax payments for each individual/family by income level. Estimated tax payments are then divided by net income (i.e. gross earnings minus personal income tax and employees' social security contributions plus family benefits).

Source: OECD (2008b), Taxing Wages, 2007-2008.

To mitigate the regressive impact of consumption taxes, many OECD countries apply reduced rates and exemptions for goods and services deemed to account for a large share of poorer households' consumption basket. For instance, food, water supply, medical care and public transport are often granted reduced rates or exemptions. ${ }^{31}$ This approach typically implies a considerable dead-weight loss and people at higher income levels often benefit more in absolute terms since they consume more. In the case of Mexico, the total implicit subsidy due to the zero-rating of food was estimated at some $1.8 \%$ of GDP in the mid-1990s (Dalsgaard, 2000). The distribution by income decile showed that the highest decile captured nearly $30 \%$ of this amount, while the lowest three deciles together received only $12 \%$ of the value of the subsidy. Likewise in the Czech Republic, the lower VAT rate covers about $41 \%$ of the consumption of goods and services subject to VAT, and there is only very little variation in the share of such goods in the consumption baskets of households across the income deciles. Reduced VAT rates benefit the average individual in the top income decile about 2.5 times as much as the average consumer in the bottom decile (OECD, 2010b). Moving towards better targeted aid through in-kind benefits, cash transfers and vouchers appears thus as a more effective redistribution tool (EC, 2007; Van den Noord and Heady, 2001).

\section{A limitation of the analysis: the incidence of taxes and transfers}

When assessing the impact of the tax and transfer system on income distribution, most analyses (including this paper), assume that taxes and transfers do not affect economic behaviour. In practice, taxes and transfers affect incentives to work and save. The assumption of "no behavioural response" is likely to overstate the amount of redistribution achieved by cash transfers as these also typically weaken the work incentives of recipients (Moffit, 2011). The ultimate incidence of taxes and transfers crucially depends on

31. For details, see OECD (2011b). Reduced VAT rates and exemptions are taken into account in the OECD estimates of the consumption tax rate at different income levels. 
how individuals and firms respond to a change in relative prices. The greater the responsiveness, that is, the higher the price elasticities of supply and demand, the more likely it is that someone else will bear the tax burden or somebody else will benefit from a transfer. The ultimate effect will depend on the relative size of the elasticities. For instance, if labour demand is more sensitive to wages than labour supply, then payroll taxes end up being mainly borne by the employee in the form of a lower wage. Conversely, if labour supply is relatively inelastic and labour demand is relatively elastic, then the enterprise will bear more of the tax burden.

Changes in tax progressivity may have a different impact on the labour supply of low-versus highincome earners. For low-income groups, more progressivity through earned income tax credit (EITC) schemes increases work incentives but the resulting increase in labour supply may reduce wages - the EITC may increase the dispersion of before-tax income. ${ }^{32}$ However, for high-income groups, more progressive taxes may dampen work incentives and lower working hours. This could narrow the earnings dispersion. Taxes may also affect labour demand, with potential job losses more likely to affect low-skilled workers. ${ }^{33}$

The incidence and ultimate income inequality effect of property taxes, housing transfers and consumption taxes may also differ from the first-round effect. While most property taxes are paid by owners, they may largely be passed onto renters in the form of higher rents as the supply of housing is relatively inelastic, at least in the short term. Similarly, housing cash transfers targeted on low-income groups may be reflected in higher rents, in which case they benefit the (higher-income) owners. ${ }^{34}$ Consumption taxes will be paid by consumers in the case of strong competition. However, the degree of competition could differ for different goods and services. As an example, recent cuts in French consumption taxes on restaurants have not been fully passed on to consumers. They have partly financed higher wages and employment as well as raised profit margins. These examples suggest that the overall distributional impact of taxes may partly depend on behavioral responses.

\section{Tax and cash transfer policy indicators help identify reform options and types of welfare systems}

Countries rely on various tax and transfers instruments which differ in their design and impact on the income distribution. As discussed above, there are wide variations in the size, mix and progressivity of both taxes levied on and cash transfers paid to households. Indicators on tax and transfer policies have been assembled, which were brought together in country profiles (Figure 15 and Annex 3). The country profiles put the tax and transfer policy framework into an international perspective and allow the identification of reform options to address income inequality. Indicators on tax and transfers policies have also been used to identify groups of countries sharing broadly comparable welfare systems.

32. Rothstein (2008) found for the United States that the EITC increases labour supply and studied the effect on wages. Low-skilled single mothers keep only $\$ 0.70$ of every dollar they receive. Employers of lowskilled labour capture $\$ 0.72$ (of which about $40 \%$ from single mothers and the rest from ineligible workers whose after-tax incomes fall). The net transfer to low-skilled workers is about $\$ 0.28$ per dollar spent.

33. In a perfectly competitive labour market, higher labour taxes should not affect equilibrium unemployment since workers bear the entire tax burden through lower net wages. However, if firms cannot shift the entire tax burden onto workers (for example, because of minimum wages or strong trade unions), higher taxes will reduce labour demand. Several empirical studies support this view (e.g. Belot and van Ours, 2004 and Bassanini and Duval, 2006).

34. On the final incidence of property taxes, see Fullerton and Metcalf (2011). On the impact of housing cash benefits on rents paid by low-income groups, see Conseil des Prélèvements Obligatoires (2011) and Facks (2005). 


\section{A set of policy indicators on taxes and cash transfers for each OECD country}

The redistributive impact of taxes depends on: $i$ ) a size effect (the overall tax level); ii) the tax mix (some taxes are more progressive than others) and iii) the progressivity of each tax. The same logic applies to cash transfers. For both taxes and transfers, policy indicators have been assembled for each of the three dimensions using the OECD Income Distribution and Poverty Database and various other OECD Databases. To identify the tax and transfer policy framework, the country profiles show for each country the value of each indicator compared with the OECD average. As an illustration, the main features that can be gleaned from the set of policy indicators for Australia and Germany are presented below (Figure 15). The redistributive impact of taxes and transfers is higher than the OECD average in the two countries but the size, mix and progressive nature of both taxes and transfers differ significantly.

\section{Figure 15. Tax and cash transfer policy indicators for Australia and Germany}

Australia

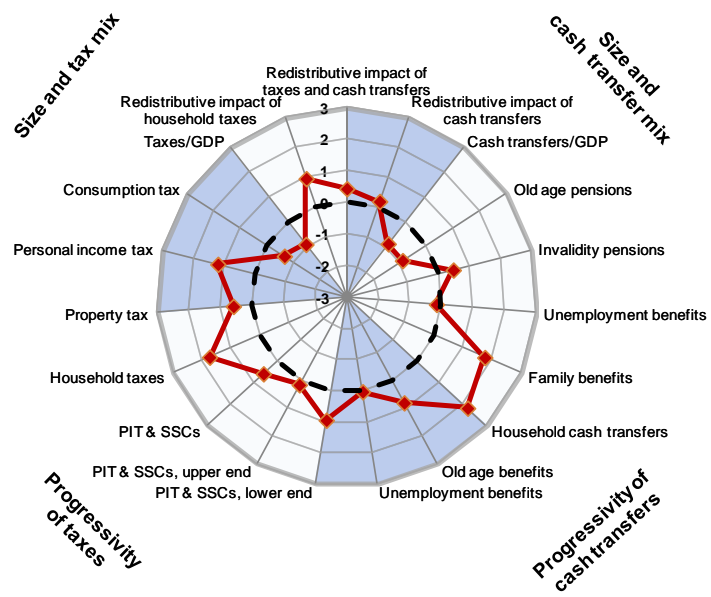

Germany

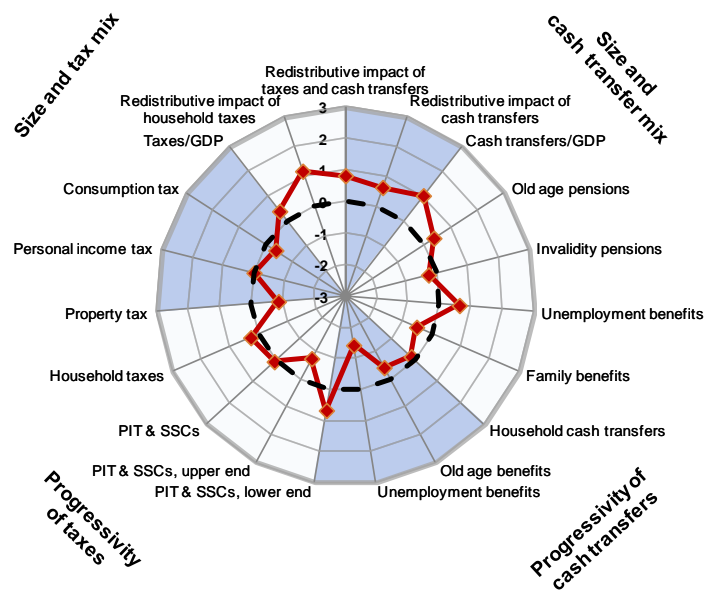

Note: The dotted line represents the OECD average, the solid line represents the country shown. Where the solid line falls inside the OECD average, the variable considered stands below the OECD average. For instance, the tax/GDP ratio in Australia is lower than in the OECD area. Inversely, where the solid line is outside the OECD average, the variable is above the OECD average (the cash transfer/GDP ratio in Germany is higher than the OECD average, for example). The indicators are Legend: presented in units of standard deviation

Size and mix of taxes

Taxes/GDP = Total tax revenue, $\%$ of GDP

Consumption tax $=$ Taxes on goods and services, $\%$ of total tax revenue Personal income tax = Income taxes on individuals or households, \% of total tax revenue

Property tax $=$ Taxes on property, $\%$ of total tax revenue

Progressivity of taxes

Household taxes $=$ Progressivity of total household taxes (Kakwani index based on household surveys)

PIT \& SSCs = Net personal income tax progressivity, synthetic indicator, based on income tax plus employee contribution schedules net of standard cash
transfers as a \% of gross wage earnings, single person without children PIT \& SSCs, upper end = As above, gap in tax rate between those earning PIT \& SSCs, upper end $=$ As above, gap in tax rate between
$167 \%$ of the average wage and those at the average wage.

PIT \& SSCs, lower end = As above, gap in tax rate between those earning the PIT \& SSCs, lower end $=$ As above, gap in tax rate be
average wage and those at $67 \%$ of the average wage

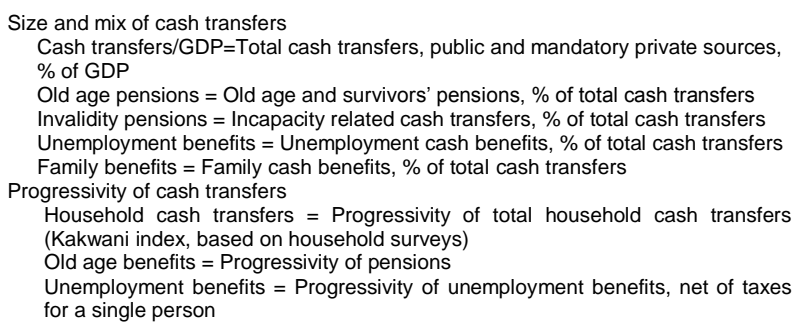

In Australia, taxes and transfers are smaller but more progressive than the OECD average

The redistributive impact of taxes and cash transfers is above the OECD average in Australia. This mainly reflects the higher redistributive impact of taxes, even though the size of the Australian tax system, as measured by the tax to GDP ratio, is considerably below the OECD average (27\% and 35\%, respectively in 2008). Both the tax mix and the progressive nature of taxes raise the redistributive impact of taxes. 
Personal income taxes account for a larger share of total taxes, while consumption taxes - which, as discussed above, tend to be regressive - play a less important role than in many other OECD countries. The data contained in the OECD Income Distribution and Poverty Database further reveal that household taxes are more progressive - as measured by a Kakwani index - than in the OECD on average. So are the personal income tax and social security contributions paid by employees (based on statutory tax schedules from the OECD Tax Database), in particular at the lower end of the income distribution. On the spending side, household cash transfers as a share of GDP are below the OECD average - 8\% versus $11.5 \%$ in 2007 according the OECD Social Expenditure Database. However, the transfer mix favours redistribution across individuals, with family benefits accounting for a relatively high share of total transfers. The progressivity of total cash transfers to households (as measured by the Kakwani index derived from the OECD Income Distribution and Poverty Database) is also above the OECD average. This also applies to old-age pensions (based on the OECD progressivity indicator), while the progressivity indicator for the unemployment benefit system is close to the OECD average.

\section{In Germany, taxes and transfers are larger but less progressive than the OECD average}

The redistributive impact of taxes and cash transfers in Germany is above the OECD average. On the tax side, the total tax-to-GDP ratio stands above the OECD average (37\% and 35\%, respectively, in 2008) while the progressivity of household taxes is close to the OECD average. However, the progressivity of the personal income tax and social security contributions is steeper at the lower end than at the upper end of the income distribution. Total cash transfers to households, at almost 16\% of GDP in 2007, are higher than in most OECD countries. Old-age pensions and unemployment benefits account for a larger share in total transfers while family benefits are less important. The redistributive impact of household transfers is small, because of the low progressivity of the two main transfer components - old-age pensions and unemployment - reflecting their largely insurance-based nature.

\section{Four tax and transfer systems can be identified}

A cluster analysis of 19 policy indicators of the size, mix and progressivity of both taxes and transfers has been performed..$^{35}$ It allows identifying four groups of countries with most similar tax and transfer systems: ${ }^{36}$

- A group of four Nordic countries (Denmark, Finland, Norway and Sweden) plus Belgium, Hungary, the Netherlands and Spain is characterised by large cash transfers to households, which are not dominated by old-age pensions and tend to be more progressive than the OECD average. The tax-to-GDP ratio is high (Spain being an exception in this regard), with a tax mix which promotes redistribution - a rather large role for personal income taxes, while consumption taxes

35. The following indicators have been used for the cluster analysis: $i$ ) for the size - the tax, transfer and in-kind service to GDP ratio; ii) for the mix: the shares of old-age pensions, disability, family and unemployment in total transfers; the shares of consumption, personal income and property taxes in total taxes; and the share of education and health in total in-kind transfers iii) for the progressivity: a Kakwani progressivity indicator for both total household taxes and total cash transfers and specific progressivity indicators for old-age pensions, unemployment, personal income tax and social security contributions. Estonia has not been included in the cluster analysis because most tax data were missing.

36. Esping-Andersen (1990) proposed a typology of welfare systems consisting of three main regimes: $i$ ) a "liberal regime" characterised by little public intervention, means-tested benefits and subsidised private welfare, mainly implemented in the English-speaking countries; ii) a "socio-democratic regime" with broad social entitlements and universal coverage, largely implemented in the Nordic countries; iii) a "conservative welfare regime" built around social insurance where entitlements depend primarily on life-long employment. 
account for a small share of total taxes. Labour income taxes are rather progressive. Overall, the redistributive impact of taxes and transfers - as measured by the decline in the concentration coefficient before and after taxes and transfers - is above the OECD average in all of these countries but Spain.

- A group of 10 continental European countries (Austria, Czech Republic, France, Germany, Greece, Italy, Luxembourg, Portugal, Slovak Republic and Slovenia) features large cash transfers to households and a high tax-to-GDP ratio. However, old-age pensions dominate cash transfers whose overall progressivity tends to be below the OECD average - the welfare system is dominated by transfers that redistribute over the lifecycle rather than across individuals. On the tax side, the personal income tax often plays a marginal role in total taxes (Germany and Italy are exceptions) and the progressivity of labour tax schedules is relatively limited.

- A group of 11 countries have in common relatively small cash transfers and taxes, combined with a large role of property and personal income taxes. A sub-group, made of Australia, Iceland, Ireland, Israel, New Zealand and the United Kingdom, is further characterised by a relatively small share of old-age pensions in total cash transfers which are, in addition, often means-tested and thus highly progressive. Another sub-group consists of Canada, Japan, Korea, Switzerland and the United States. In these countries, cash transfers are dominated by old-age pensions and are less progressive than in the first sub-group.

- A group of 4 countries - Chile, Mexico, Poland and Turkey - is characterised by relatively small cash transfers to households (Poland is an exception), which are dominated by old-age pensions and often not highly progressive. Two additional features further limit the redistributive impact of the welfare system: public spending on in-kind services (mostly education and health) as a share of GDP is low and consumption taxes play a dominant role in total taxes.

- It is interesting to note that there is a close, but not perfect, correspondence between country clusters based on tax and transfer policy indicators and country clusters based on inequality outcomes. As an illustration, the Nordic countries and Switzerland are all characterised by relatively low inequality emerging from the labour market and they appear in the same inequality outcome group (Hoeller et al., 2012). Looking at the tax and transfer side, the Nordic countries again fit within the same group because their tax and transfer policies are broadly similar. However, Switzerland is in a different policy group because it implements much less redistribution via the tax and transfer system than do the Nordic countries.

\section{The inequality and growth nexus associated with taxes and transfers}

Taxes and public spending affect both GDP per capita and the distribution of income. The redistributive implications of various taxes have been discussed above. However, the tax system - in particular the tax mix and the design of taxes - can also have an impact on GDP per capita by affecting labour utilisation and labour productivity, or both (Johansson et al., 2008). Similarly, public spending programmes also affect income levels. Some tax reform options appear to be win-win options - improving growth prospects and narrowing the distribution of income. Most, however, may imply trade-offs between these objectives. To assess possible policy trade-offs and complementarities between growth and income distribution objectives, growth-enhancing policy reforms are classified into three categories: $i$ ) those that are likely to reduce income inequality; ii) those that are likely to raise it; and iii) those that seem to have an ambiguous effect. Table 2 summarises the main findings. 
ECO/WKP(2012)3

Table 2. The inequality and growth nexus associated with taxes

\begin{tabular}{|c|c|c|c|}
\hline Tax policies & $\begin{array}{l}\text { Income } \\
\text { equality }\end{array}$ & $\begin{array}{l}\text { GDP per } \\
\text { capita }\end{array}$ & Comments \\
\hline Increasing total tax revenues & $\sim,+$ & - & $\begin{array}{l}\text { The impact of taxes on income distribution depends } \\
\text { on the level of taxation, the tax mix and the use of } \\
\text { tax revenues, but if tax systems are progressive } \\
\text { overall, equality is enhanced. } \\
\text { Taxes dampen incentives to work, save and invest } \\
\text { and are thus detrimental to growth. But some taxes } \\
\text { have a less adverse effect than others. }\end{array}$ \\
\hline \multicolumn{4}{|l|}{$\begin{array}{l}\text { Changing the tax mix while keeping } \\
\text { total tax revenues constant }\end{array}$} \\
\hline $\begin{array}{l}\text { Moving from the personal income tax to } \\
\text { consumption taxes }\end{array}$ & - & + & $\begin{array}{l}\text { The personal income tax tends to be progressive } \\
\text { while the consumption tax is regressive. } \\
\text { The personal income tax reduces work and saving } \\
\text { incentives. A shift from direct to indirect taxes would } \\
\text { raise output. }\end{array}$ \\
\hline $\begin{array}{l}\text { Moving from social security } \\
\text { contributions to consumption taxes }\end{array}$ & $\begin{array}{c}- \\
\text { ( in the } \\
\text { long-run) }\end{array}$ & + & $\begin{array}{l}\text { Those not employed (e.g. pensioners, unemployed) } \\
\text { would suffer most from a decline in their living } \\
\text { standards. } \\
\text { The cost of labour would decline and/or incentives } \\
\text { to work would increase, raising the growth potential. } \\
\text { In the long run, this may help to reduce income } \\
\text { dispersion. }\end{array}$ \\
\hline $\begin{array}{l}\text { Moving from labour income to property } \\
\text { and capital taxes: } \\
\text { * to wealth, inheritance and capital } \\
\text { income taxes, such as capital gains } \\
\text { taxes }\end{array}$ & $\sim$ & + & $\begin{array}{l}\text { Wealth and inheritance taxes tend to be } \\
\text { progressive. The distributive impact depends on the } \\
\text { relative progressivity of income versus wealth and } \\
\text { inheritance taxes. } \\
\text { Real estate taxes are often less progressive than } \\
\text { the personal income tax and can even be } \\
\text { regressive. } \\
\text { Property taxes are among the least harmful for } \\
\text { growth. Moving from income to property taxes tends } \\
\text { to improve incentives to work and invest, and thus } \\
\text { raise output, at least in the short and medium-term. }\end{array}$ \\
\hline $\begin{array}{l}\text { Cutting tax expenditures and marginal } \\
\text { rates }\end{array}$ & $\begin{array}{l}+ \text { in most } \\
\text { cases } \\
\text { (- for in- } \\
\text { work tax } \\
\text { credits) }\end{array}$ & + & $\begin{array}{l}\text { Most tax expenditures benefit high-income groups } \\
\text { (in-work tax credits, such as EITC schemes and } \\
\text { other tax expenditures targeted on low-income } \\
\text { groups are the exception). Cutting tax expenditure } \\
\text { would narrow the distribution of disposable income. } \\
\text { Cutting marginal rates improves incentives to work, } \\
\text { save and invest, and thus lifts GDP per capita. }\end{array}$ \\
\hline \multicolumn{4}{|l|}{$\begin{array}{l}\text { Increasing the progressivity of taxes } \\
\text { (revenue-neutral) }\end{array}$} \\
\hline $\begin{array}{l}\text { Increasing the progressivity of the } \\
\text { personal income tax } \\
\text { * increase in top rates, combined } \\
\text { with: } \\
\text { * expand EITC schemes or tax free } \\
\text { allowances }\end{array}$ & $\left\{\begin{array}{l}+ \\
+ \\
+\end{array}\right.$ & $\left.\begin{array}{l}\sim \\
- \\
+\end{array}\right\}$ & $\begin{array}{l}\text { In-work tax credits narrow the income distribution } \\
\text { and raise incentives to work. } \\
\text { On the other hand, higher top rates may reduce } \\
\text { working hours, as well as productivity by } \\
\text { undermining incentives to learn, invest and } \\
\text { innovate. The GDP per capita impact is thus } \\
\text { indeterminate. }\end{array}$ \\
\hline
\end{tabular}

Note: Concerning equality effects, a plus sign indicates more equality and a minus sign indicates less equality (i.e., more inequality). For both the equality and growth effect, a tilde indicates an ambiguous effect. 


\section{Growth-enhancing tax policy reforms that are likely to reduce income inequality}

Re-assessing those tax expenditures that benefit mainly high-income groups (e.g. tax reliefs on mortgage interest). Cutting back tax expenditures is likely to be beneficial both for long-term GDP per capita, allowing a reduction in marginal tax rates, and for a more equitable distribution of income as tax expenditures benefit disproportionally high-income earners. Cutting tax expenditure would also reduce the complexity of the tax system, and thus tax compliance and collection costs.

Reducing distortions in taxing capital income. Tax reliefs granted to specific savings instruments such as reduced taxation of capital gains resulting from the sale of a principal or secondary residence should be reconsidered since they often distorts resource allocation, without boosting total savings and growth, and benefit mainly high-income groups. Specific tax relief may also provide tax avoidance instruments for the top-income earners. In particular, there is little justification for tax breaks for stock options and carried interest. Raising such taxes would cater to equity objectives and allow a cut in marginal labour income tax rates.

\section{Growth-enhancing tax policy reforms that are likely to raise income inequality}

Shifting the tax mix from personal and corporate income taxes towards real estate and consumption taxes. Empirical evidence suggests that recurrent taxes on immovable property are among the least distortive taxes, followed by consumption taxes (Johansson et al., 2008). Personal and corporate income taxes as well as social security contributions are the most distortive as they have sizable adverse effects on labour utilisation, productivity and capital accumulation. Shifting the tax mix away from such taxes should thus raise living standards. However, there is likely to be an important trade-off with the income distribution objective since personal income taxes are progressive, while real estate and consumption taxes tend to be regressive. Targeted transfers can counteract the resulting increase in the regressivity of the tax system and reduce the severity of the trade-off.

\section{Growth enhancing tax policy reforms that have an uncertain impact on income inequality}

Moving from income to wealth or inheritance tax. Personal income taxes, wealth and inheritance taxes all tend to be progressive. The distributional impact of a move from income to wealth or inheritance taxes would thus depend on the relative progressivity of each tax but may be broadly neutral. The impact on growth should, however, be positive since such property taxes are among the least distortive taxes.

Moving from social security contributions (or flat labour income taxes) to consumption taxes. Lowering the tax burden on labour could lead to increases in both labour supply and demand, boosting economic growth. The increase in consumption taxes would fall on wage earners but also on benefit and capital income recipients. If benefit indexation is incomplete, benefit recipients may suffer a loss of real income and the rise in consumption taxes may have undesirable distributional effects. Incentives to work would increase, however, thus reducing unemployment traps and the dispersion of labour income. Wages would also likely reflect, at least partly, the increase in consumption taxes, thus affecting employment.

\section{The impact of transfer policies on growth very much depends on their design}

As discussed above, transfers are usually progressive, although their degree of progressivity depends on their design features, e.g. on the relative portion of flat versus income-related benefits. Effects on GDP per capita also depend on the design of transfer systems as well as flanking measures. While many transfers may undermine work incentives with adverse effects on hours worked and income levels, this need not be the case if they are properly designed or accompanied by offsetting measures. For instance, high, but degressive, unemployment benefits may have only limited adverse effects on work incentives when a coherent activation strategy is in place. Likewise, high old-age pension benefit replacement rates 
may not affect labour force participation of older workers much, if the system is actuarially neutral, as may disability benefit schemes that involve strict eligibility criteria and regular re-assessments of work capacity. Targeted transfers are likely to have adverse incentive effects during the withdrawal phase, but these can be mitigated by avoiding threshold effects and the associated spikes in marginal effective tax rates. Universal benefits are likely to have comparatively lower incentive effects, but a higher tax take which itself entails economic distortions - is needed to finance them.

\section{Options for further work}

Assessing the redistributive impact of taxes and transfers and investigating trade-offs or complementarities with growth-oriented policies have been the main focus of this paper. While covering a lot of ground, several topics that are of interest from a policy perspective could only be touched upon and it may be interesting to investigate them in more depth. In particular:

- Assessing the redistributive and growth impact of taxes and transfers should, in principle, be done simultaneously. Raising the overall tax level would dampen incentives to work, save and invest and is therefore detrimental to growth. However, the final impact would depend on the use of tax revenues. Public investment (e.g. fostering human capital) could spur the growth potential and outweigh the detrimental effects of higher taxation. Likewise, for transfers, the impact on growth and income distribution depends on their financing. Using a computable General Equilibrium (CGE) model would have clear advantages and would also allow addressing incidence issues. Still, the design of tax and benefit systems matters a lot and is country specific while various other policies impinging on the distribution of income and economic activity are also difficult to parameterise.

- The recent crises, fiscal stimulus packages and more recently fiscal consolidation measures are likely to have profound distributional consequences. Many measures have been taken during the economic crisis, which have affected the distribution of income. How the overall income distribution has changed during the crisis and how the stimulus measures have affected it cannot be assessed yet (and the counterfactual may never be known). Many countries have introduced targeted support measures, not least for the unemployed (eligibility and duration of unemployment benefits). Such measures have probably mitigated the impact of higher unemployment on income inequality. This raises the question whether a temporary increase in inequality is best addressed by temporary measures, or whether the permanent framework policy settings are adequate. The OECD income distribution and poverty data do not cover the period after 2008 and work on this topic could only be undertaken in a few years.

- The lifetime perspective is usually missing in work on income distribution, in particular concerning international comparisons. However, annual data on income inequality may be a poor proxy for income inequality across individuals in a lifetime perspective. Likewise, a large part of the tax and transfer systems entails redistribution over the life-cycle rather than across individuals, though cross-country estimates are not currently available. More work could be carried out to better account for the lifetime perspective.

- Better assessing the distributional impact of in-kind transfers on income distribution should be a priority. The size of in-kind services (health, education and other social services) is more important than that of cash transfers on average in OECD countries - 13 versus $11 \%$ of GDP in 2007. These services may have large consequences on growth, income distribution and poverty. However, household surveys provide little information on who benefits from these services and imputation rules reflect mainly demographic factors (age, sex and the presence of children). They do not account for whether these benefits are means-tested or for the actual use of these services. Further work to better understand the impact of in-kind transfers on income distribution would be an important addition to the existing literature on income redistribution. 


\section{Bibliography}

Adema, W. and M. Ladaique (2009), "How Expensive is the Welfare State? Gross and Net Indicators in the OECD Social Expenditure Database (SOCX)", OECD Social, Employment and Migration Working Papers, No. 92, OECD Publishing.

Alvaredo, F. et al. (2011), The Top Incomes Database, http://www.parisschoolofeconomics.ew/en/news/the-topincomes-database-new-website/.

Antolin P., A. de Serres, and C. de la Maisonneuve (2004), "Long-Term Budgetary Implications of Tax-Favoured Retirement Plans”, OECD Economics Department Working Paper, No. 393.

Bassanini, A. and R. Duval (2006), "Employment Patterns in OECD Countries: Reassessing the Role of Policies and Institutions", OECD Economics Department Working Paper, No. 486.

Belot, M. and J. Van Ours (2004), "Does the Recent Success of Some OECD Countries in Lowering their Unemployment Rates Lie in the Clever Design of their Labour Market Reform?", Oxford Economic Papers, Vol. 56, No. 4.

Benítez-Silva, H., R. Disney and S. Jimenez-Martin (2010), "Disability, Capacity for Work and the Business Cycle", Economic Policy, 63, July, pp. 483-536.

Burman, L.E. and D.P. Moynihan (2011), "Tax Reform Options: Marginal Rates on High-income Taxpayers, Capital Gains, and Dividends", Statement before the Senate Committee on Finance, September 2011, http://www.urban.org/uploadedpdf/901447-Burman-Tax-Reform-Options.pdf.

Burman, L.E., E. Toder, and C. Geissler (2008), "How Big are Total Individual Income Tax Expenditure, and Who Benefits from Them?" Tax Policy Center Discussion Paper, No. 16, the Urban Institute, Washington DC.

Chawla, R.K. and T. Wannell (2003), "Property Taxes", in Perspectives, Statistics Canada, July, Vol. 4, No. 7, http://www.statcan.gc.ca/pub/75-001-x/75-001-x2003007-eng.pdf

Christia, J.P. (2007),"The Empirical Relationship between Lifetime Earnings and Mortality, CBO Working Paper Series, No. 20071.

Conseil des Prélèvements Obligatoires (2011), Prélèvements obligatoires sur les ménages: progressivité et effets redistributifs, May, http://www.ccomptes.fr/fr/CPO/documents/divers/Rapport_conseil_ prelevements_obligatoires_prelevements_obligatoires_sur_les_menages_11052011.pdf

Dalsgaard, T. (2000), "The Tax system in Mexico - A Need for Strengthening the Revenue-Raising Capacity", OECD Economics Department Working Paper, No. 233.

Davies, J.B., S. Sandström, A. Shorrocks and E. Wolff (2009), "The Level and Distribution of Global Household Wealth", The Economic Journal, 121, Royal Economic Society, Blackwell Publishing. 
Diamond P. and E. Saez (2011), "The Case for a Progressive Tax: From Basic Research to Policy Recommendations", Journal of Economic Perspectives, Volume 25, Number 4, Fall 2011, pp. 165190.

Duncan, D. and K. Sabirianova Peter (2008), “Tax Progressivity and Income Inequality”, Andrew Young School of Policy Studies, Georgia State University, mimeo.

Esping-Andersen G. (1990), The Three Worlds of Welfare Capitalism. Princeton, N.J. Princeton University Press.

European Commission (2007), "Study on Reduced VAT Applied to Goods and Services in the Member States of the European Union", http://ec.europa.eu/taxation_customs/resources/documents/taxation /vat/how_vat_works/rates/study_reduced_vat.pdf

Facks, G. (2005), "Pourquoi les Ménages Paient-ils des Loyers de Plus en Plus Élevés ? L’incidence des Aides au Logement en France (1973-2001)", Economie et Statistiques, No. 381-382.

Fredriksen, K. (2012), "Less Income Inequality and More Growth - Are They Compatible? Part 6. The Distribution of Wealth", OECD Economics Department Working Paper, No. 929.

Fuest, C., J. Niehues and A. Peichl (2010), "The Redistributive Effects of Tax Benefit Systems in the Enlarged EU”, Public Finance Review, Issue 38, July, pp. 473-500.

Fullerton, D. and G.E. Metcalf (2011), "Tax incidence", in: Handbook of Public Economics, Vol. 4, http://www.sciencedirect.com/science/handbooks/15734420

Garfinkel, I., L. Rainwater, T.M. Smeeding (2006), “A Re-examination of Welfare States and Inequality in Rich Nations: How In-kind Transfers and Indirect Taxes Change the Story", Journal of Policy Analysis and Management, Vol. 25, No. 4.

Garrett, D.M. (1995), "The Effect of Differential Mortality Rates on the Progressivity of Social Security", Economic Inquiry, Vol. 33(3).

Goda, S.G., J.B. Shoven and S.N. Slavov (2009), "Differential Mortality by Income and Social Security Progressivity”, SIEPR Discussion Paper, No. 08-6.

Hachon, C. (2009), "Who Really Benefits from Pension Systems? When Life Expectancy Matters", Revue d'économie politique, Vol. 119(4), pp. 613-632.

Hoeller, P., I. Joumard, M. Pisu and D. Bloch (2012), "Less Income Inequality and More Growth - Are They Compatible? Part 1. Mapping Inequality Across the OECD", OECD Economics Department Working Paper, No. 924.

Immervoll, H. and L. Richardson (2011), "Redistribution Policy and Inequality Reduction in OECD Countries: What Has Changed in Two Decades?", OECD Social, Employment and Migration Working Papers, No. 122, OECD Publishing.

Johansson, Å. et al. (2008), “Taxation and Economic Growth”, OECD Economics Department Working Paper, No. 620.

Joumard, I. (2001), "Tax Systems in European Union Countries", OECD Economics Department Working Paper, No. 301. 
Kakwani, N. (1977), "Measurement of Tax Progressivity: An International Comparison", the Economic Journal, Vol. 87, March, pp. 71-80.

Kakwani, N. (1979), "Measurement of Tax Progressivity: a Reply", the Economic Journal, Vol. 89, No. 355, September, pp. 653-657.

Keenay, G., and E. Whitehouse (2003), "The Role of the Personal Tax System in Old-Age Support: A Survey of 15 Countries", Fiscal Studies, Vol. 24(1), pp. 1-21.

Koske, I., Fournier, J.-M. and I. Wanner (2012), "Less Income Inequality and More Growth - Are They Compatible? Part 2. The Distribution of Labour Income", OECD Economics Department Working Paper, No. 925.

Landais, C., T. Piketty and E. Saez (2011), Pour une révolution fiscale, Editions Seuil.

Marical, F. (2009), "Les Mécanismes de Réduction des Inégalités de Revenus en 2008”, France, Portrait Social - Édition 2009, INSEE, http://www.insee.fr/fr/ffc/docs_ffc/ref/FPORSOCO9H.PDF

Marmot, M.G. and M.J. Shipley (1996), "Do Socioeconomic Differences in Mortality Persist after Retirement? 25 Year follow up of Civil Servants from the First Whitehall Study", BMJ, Vol. 313.

Matsaganis, M. and M. Flevotomou (2007), "The Impact of Mortgage interest Tax Relief in the Netherlands, Sweden, Finland, Italy and Greece", EUROMOD Working Paper, No. EM2/07 http://www.iser.essex.ac.uk/publications/working-papers/euromod/em2-07.pdf

Moffit, R.A. (2011), "Welfare Programs and Labour Supply”, Handbook of Public Economics, Vol. 4. http://www.sciencedirect.com/science/handbooks/15734420

Musgrave, R.A. and T. Thin (1948), "Income Tax Progression 1929-48", Journal of Political Economy, Vol. 56, pp. 489-514.

Noord, P. van den and C. Heady (2001), "Surveillance of Tax Policies: a Synthesis of Findings in Economic Surveys", OECD Economics Department Working Paper, No. 303.

Norregaard, J. (1990), "Progressivity of Income Tax Systems", OECD Economic Studies, No. 15, Autumn, OECD Publishing.

OECD (2006), OECD Tax Policy Studies: Fundamental Reform of Personal Income Tax, OECD Publishing.

OECD (2008a), Growing Unequal? Income Distribution and Poverty in OECD Countries, OECD Publishing.

OECD (2008b), Taxing Wages 2008-2009, OECD Publishing.

OECD (2009), National Accounts at a Glance 2009, OECD Publishing.

OECD (2010a), Education at a Glance 2010, OECD Publishing.

OECD (2010b), OECD Economic Surveys: Czech Republic 2010, OECD Publishing.

OECD (2010c), Revenue Statistics, OECD Publishing. 
OECD (2010d), Sickness, Disability and Work: Breaking the Barriers, OECD Publishing.

OECD (2010e), Tax Expenditures in OECD Countries, OECD Publishing.

OECD (2011a), Divided We Stand: Why Inequality Keeps Rising, OECD Publishing.

OECD (2011b), Consumption Tax Trends 2010: VAT/GST and Excise Rates - Trends and Administration Issues, OECD Publishing.

OECD (2011c), Pensions at a Glance 2011, OECD Publishing.

ONS (2010), "Income Inequality Remains Stable", http://www.statistics.gov.uk/pdfdir/taxbhinr0610.pdf

Palameta, B. and I. Macredie (2005), "Property Taxes Relative to Income", Statistics Canada, perspectives, March, http://www.statcan.gc.ca/pub/75-001-x/10305/7796-eng.pdf

Piketty, T. (2010), "On the Long-Run Evolution of Inheritance: France 1820-2050", Paris School of Economics Working Paper, May.

Piketty, T. and E. Saez (2007), "How Progressive is the US Federal Tax System? A Historical and International Perspective", Journal of Economic Perspectives, Vol. 21, No. 1, Winter, http://www.jstor.org/stable/30033699

Pisu, M. (2012), "Less Income Inequality and More Growth - Are They Compatible? Part 5. Poverty in OECD Countries", OECD Economics Department Working Paper, No. 928.

Poterba, J.M. (1989), "Lifetime Incidence and the Distributional Burden of Excise Taxes", American Economic Review, 79(2).

Prasad, M. and Y. Deng (2009), "Taxation and the Worlds of Welfare", Luxembourg Income Study, Working Paper Series, No. 480, http://www.lisproject.org/publications/liswps/480.pdf

Price, R. and T.T. Dang (2011), “Adjusting Fiscal Balances for Asset Price Cycles”, OECD Economics Department Paper, No. 868.

Roach, B. (2003), "Progressive and Regressive Taxation in the United States: Who's Really Paying (and Not Paying) their Fair Share?" Global Development and Environment Institute Working Paper No. 03-10.

Rothstein, J. (2008), "The Unintended Consequences of Encouraging Work: Tax Incidence and the EITC", CEPS Working Paper, No. 165.

Sabirianova Peter, K., S. Buttrick and D. Duncan (2008), "Global Reform of Personal Income Taxation, 1981-2005: Evidence from 189 Countries”, IZA Discussion Paper, No. 4228, http://ftp.iza.org/dp4228.pdf.

Sen, A. (1983) "Poor, Relatively Speaking”, Oxford Economic Papers, Vol. 35(2).

Sen, A. (1992), Inequality Reexamined, Clarendon Press, Oxford.

Ståhlberg, A. (2007), "Redistribution across the Life Course in Social Protection Systems", in: Modernising Social Policy for the New Life Course, OECD Publishing. 
Stiglitz, J., A. Sen and J.P. Fitoussi (2009), Report by the Commission on the Measurement of Economic Performance and Social Progress.

Toder, E.J., B.H. Harris and K. Lim (2009) "Distributional Effects of Tax Expenditures", Tax Policy Center Discussion Paper, the Urban-Brookings Tax Policy Institute, http://www.taxpolicycenter.org/UploadedPDF/411922_expenditures.pdf

Waldron, H. (2007), "Trends in Mortality Differentials and Life Expectancy for Male Social Security-Covered Workers, by Socioeconomic Status", Social Security Bulletin, Vol. 67(1).

Warren, N. (2008), "A Review of Studies on the Distributional Impact of Consumption Taxes in OECD Countries", OECD Social, Employment and Migration Working Paper, No. 64.

Whitehouse, E. (2006), "New Indicators of 30 OECD Countries' Pension Systems”, PEF, 5 (3), Cambridge University Press, November.

Whitehouse, E., A. D'Addio, R. Chomik and A. Reilly (2009), “Two Decades of Pension Reform: What has been Achieved and What Remains to be Done?", The Geneva Papers, 34, The International Association for the Study of Insurance Economics. [check text --- should be Whitehouse et al?]; Williams, R. (2011) "Who Benefits from Tax Expenditures?", the Tax Policy Center, Urban Institute and Brookings Institution, http://www.taxpolicycenter.org/UploadedPDF/1001537-Who-BenefitsFrom-Expenditures.pdf

Williams, R. (2011), “Who Benefits From Tax Expenditures?” Tax Notes, Tax Policy Center, Urban and Brookings Institution, 2 May 2011.

Yoo, K.-Y. and A. de Serres (2004), "Tax Treatment of Private Pension Savings in OECD Countries and the Net Tax Cost Per Unit of Contribution to Tax-Favoured Schemes", OECD Economics Department Working Paper, No. 406. 
Annex 1

\section{Data sources and their pros and cons}

The OECD Income Distribution and Poverty Database is the main database used in this paper to assess the redistributive impact of taxes and transfers. The data are based on household surveys, carried out by national experts who apply common conventions and definitions, thus enhancing cross-country comparability. ${ }^{37}$ Data from tax returns can also be used when addressing specific issues - in particular top incomes - or for providing a long-term perspective. The Top Incomes Database (Alvaredo et al., 2011) contains information over a very long time span for 17 OECD countries and several non-OECD countries. Both tax and household survey income data have limitations which are summarised below. To complement data from household surveys and from tax returns, OECD data on actual government spending and revenues, as well as information from tax schedules and benefits principles are used in the paper to draw cross-country comparisons.

\section{Data from household surveys: main limitations}

- Household surveys tend to be biased at both ends of the income ladder. The richest often fail to respond and, when they do, they tend to under-report their income. The poorest may be too marginalised to respond. Inequality thus tends to be underestimated.

- Non-response rates and misreporting varies across countries. As an illustration, in the EU Statistics on Income and Living Conditions (EU-SILC), the 2008 non-response rate exceeded $30 \%$ in Belgium, Denmark, Luxembourg and Norway and stood below 10\% in Portugal and the Slovak Republic (Wolff et al., 2010). Misreporting may also vary significantly across countries (Kyyrä, 2011), further undermining the accuracy of cross-country comparisons. The non-response rate may also be higher for some income components, such as the income from self-employment and capital income (Verma and Betti, 2010). In practice, country rankings for the inequality of capital income vary considerably when moving from one household survey to another, e.g. from the LIS to the OECD database.

- Most household surveys cover only those living in private households. The data typically omit those living in institutions, such as old people's homes, military camps and prisons. They also omit the homeless. The impact of these omissions will differ from country to country. Moreover, estimates of Gini indices from national surveys for the working age population can be strongly affected by the share of people with zero income. It is particularly high in Japan, Korea and Poland, resulting in a high Gini index. This may partly reflect differences in questionnaire design and in responding practices.

- The income data refer to cash income and thus exclude imputed components such as home production and imputed rent - the data on adjusted disposable income, with the imputation of public spending on health, education and social housing, being the main exception.

37. See OECD (2008a), Table 1.A1.1 for detailed country information and Expert Group on Household Income Statistics. 
- Social security contributions paid by employers - which finance a large part of the welfare system in some countries - are not included while social security contributions paid by households are, in principle, included. This makes it difficult to draw cross-country comparisons on the size and effect of the tax system based on household surveys.

- Some income components are not treated consistently across household surveys, distorting crosscountry comparisons. For instance, occupational pensions should be treated as capital income according to the OECD terms of reference, but in practice, they are sometimes treated as cash transfers (for instance, in France).

\section{Data from tax returns: main limitations}

Tax data should in principle cover all high income recipients, i.e. provide "census" rather than sample data. They do not suffer from the high non-response rates characterising household surveys for high income levels. Although tax evasion and avoidance may distort the data, the bias is generally perceived to be smaller than for household surveys since the income data are audited by the tax authorities. Using tax data, the income share of the top $10 \%$ richest is often considerably higher than when using household surveys. Still tax data also have limitations, in particular:

a. Under-declaration of income can be significant and varies across countries, reflecting the penalties imposed for under-declaration of income and the efficiency of tax authorities in fighting tax evasion.

b. The tax authorities generally only collect information on income that is potentially taxable. Differences in tax codes can thus lead to differences in the concept of income used in different countries. In particular, imputed rent from owner-occupied housing is not covered in most countries and capital gains are covered only in the countries where they are taxed.

c. The tax unit (joint versus individual filing) varies between countries.

d. Possibilities for tax planning and tax avoidance will affect the amount of income declared in tax returns.

Relying on tax data for assessing the income at the bottom of the distribution may also be difficult since, in some countries, people are not required to declare their income if it falls below the taxable income threshold. 
Additional information

Table A2.1. Cash transfers by type: redistributive impact, size and progressivity - estimates from household surveys

\begin{tabular}{|c|c|c|c|c|c|c|c|c|c|c|c|c|c|c|c|c|c|c|}
\hline & \multicolumn{3}{|c|}{ Old-age pensions } & \multicolumn{3}{|c|}{ Disability pensions } & \multicolumn{3}{|c|}{ Family cash benefits } & \multicolumn{3}{|c|}{ Unemployment benefits } & \multicolumn{3}{|c|}{ Housing benefits } & \multicolumn{3}{|c|}{ Total transfers } \\
\hline & $\begin{array}{l}\text { Redistribu- } \\
\text { tive impact }\end{array}$ & Size & $\begin{array}{l}\text { Progres- } \\
\text { sivity }\end{array}$ & $\begin{array}{l}\text { Redistribu- } \\
\text { tive impact }\end{array}$ & Size & $\begin{array}{l}\text { Progres- } \\
\text { sivity }\end{array}$ & $\begin{array}{l}\text { Redistribu- } \\
\text { tive impact }\end{array}$ & Size & $\begin{array}{l}\text { Progres- } \\
\text { sivity }\end{array}$ & $\begin{array}{l}\text { Redistribu- } \\
\text { tive impact }\end{array}$ & Size & $\begin{array}{l}\text { Progres- } \\
\text { sivity }\end{array}$ & $\begin{array}{l}\text { Redistribu- } \\
\text { tive impact }\end{array}$ & Size & $\begin{array}{l}\text { Progres- } \\
\text { sivity }\end{array}$ & $\begin{array}{c}\text { Redistribu } \\
\text {-tive } \\
\text { impact }\end{array}$ & Size & $\begin{array}{l}\text { Progres- } \\
\text { sivity }\end{array}$ \\
\hline AUS & 0.034 & 0.038 & 0.907 & 0.014 & 0.017 & 0.792 & 0.025 & 0.032 & 0.771 & 0.008 & 0.009 & 0.879 & 0.000 & 0.000 & .. & 0.097 & 0.116 & 0.837 \\
\hline AUT & 0.020 & 0.206 & 0.097 & 0.005 & 0.025 & 0.203 & 0.025 & 0.058 & 0.433 & 0.009 & 0.017 & 0.520 & 0.001 & 0.002 & 0.825 & 0.052 & 0.275 & 0.189 \\
\hline BEL & 0.063 & 0.123 & 0.510 & 0.013 & 0.018 & 0.695 & 0.018 & 0.045 & 0.396 & 0.037 & 0.058 & 0.641 & 0.000 & 0.000 & 0.573 & 0.119 & 0.220 & 0.541 \\
\hline CAN & 0.176 & 0.350 & 0.503 & 0.000 & 0.000 & .. & 0.014 & 0.017 & 0.868 & 0.008 & 0.018 & 0.468 & 0.000 & 0.000 & .. & 0.060 & 0.109 & 0.549 \\
\hline CZE & 0.070 & 0.133 & 0.523 & 0.014 & 0.029 & 0.474 & 0.019 & 0.028 & 0.679 & 0.005 & 0.008 & 0.691 & 0.003 & 0.003 & 1.075 & 0.114 & 0.200 & 0.569 \\
\hline DNK & 0.057 & 0.065 & 0.881 & 0.011 & 0.019 & 0.564 & 0.009 & 0.020 & 0.430 & 0.040 & 0.067 & 0.605 & 0.009 & 0.009 & 0.965 & 0.118 & 0.168 & 0.703 \\
\hline FIN & 0.016 & 0.020 & 0.807 & 0.001 & 0.003 & 0.291 & 0.016 & 0.036 & 0.439 & 0.019 & 0.032 & 0.607 & 0.008 & 0.009 & 0.974 & 0.065 & 0.111 & 0.584 \\
\hline FRA & 0.019 & 0.191 & 0.097 & 0.003 & 0.012 & 0.207 & 0.017 & 0.036 & 0.480 & 0.009 & 0.034 & 0.273 & 0.015 & 0.016 & 0.904 & 0.056 & 0.262 & 0.215 \\
\hline DEU & 0.042 & 0.131 & 0.322 & 0.000 & 0.000 & .. & 0.019 & 0.040 & 0.466 & 0.018 & 0.026 & 0.699 & 0.005 & 0.011 & 0.428 & 0.086 & 0.208 & 0.411 \\
\hline IRL & 0.034 & 0.044 & 0.780 & 0.014 & 0.019 & 0.734 & 0.041 & 0.062 & 0.666 & 0.015 & 0.027 & 0.534 & 0.004 & 0.005 & 0.918 & 0.100 & 0.148 & 0.674 \\
\hline ISL & 0.022 & 0.056 & 0.398 & 0.006 & 0.026 & 0.233 & 0.013 & 0.025 & 0.502 & 0.003 & 0.006 & 0.499 & 0.006 & 0.013 & 0.468 & 0.045 & 0.125 & 0.357 \\
\hline ITA & 0.045 & 0.183 & 0.245 & 0.000 & 0.000 & .. & 0.014 & 0.014 & 0.986 & 0.002 & 0.005 & 0.502 & 0.000 & 0.000 & .. & 0.073 & 0.224 & 0.327 \\
\hline LUX & 0.029 & 0.162 & 0.178 & 0.009 & 0.027 & 0.346 & 0.024 & 0.065 & 0.373 & 0.007 & 0.015 & 0.439 & 0.000 & 0.000 & .. & 0.066 & 0.247 & 0.266 \\
\hline NLD & 0.031 & 0.057 & 0.545 & 0.014 & 0.029 & 0.494 & 0.028 & 0.038 & 0.748 & 0.006 & 0.017 & 0.359 & 0.005 & 0.005 & 1.032 & 0.080 & 0.137 & 0.583 \\
\hline NOR & 0.043 & 0.065 & 0.654 & 0.018 & 0.040 & 0.442 & 0.011 & 0.025 & 0.451 & 0.006 & 0.012 & 0.507 & 0.002 & 0.002 & 1.040 & 0.092 & 0.163 & 0.568 \\
\hline $\mathrm{POL}$ & 0.038 & 0.213 & 0.177 & 0.020 & 0.051 & 0.399 & 0.013 & 0.020 & 0.654 & 0.007 & 0.024 & 0.309 & 0.002 & 0.003 & 0.703 & 0.071 & 0.280 & 0.252 \\
\hline PRT & 0.019 & 0.144 & 0.131 & 0.008 & 0.018 & 0.437 & 0.007 & 0.016 & 0.428 & 0.006 & 0.022 & 0.266 & 0.001 & 0.004 & 0.331 & 0.043 & 0.198 & 0.216 \\
\hline SVK & 0.052 & 0.136 & 0.380 & 0.009 & 0.016 & 0.567 & 0.015 & 0.037 & 0.390 & 0.004 & 0.008 & 0.451 & 0.000 & 0.000 & .. & 0.092 & 0.217 & 0.423 \\
\hline SWE & 0.063 & 0.111 & 0.569 & 0.001 & 0.010 & 0.133 & 0.021 & 0.047 & 0.456 & 0.016 & 0.033 & 0.480 & 0.010 & 0.009 & 1.041 & 0.121 & 0.228 & 0.528 \\
\hline $\mathrm{CHE}$ & 0.040 & 0.080 & 0.501 & 0.000 & 0.000 & .. & 0.006 & 0.018 & 0.329 & 0.007 & 0.014 & 0.465 & 0.000 & 0.000 & . & 0.057 & 0.117 & 0.483 \\
\hline GBR & 0.034 & 0.051 & 0.660 & 0.014 & 0.021 & 0.656 & 0.000 & 0.000 & & 0.000 & 0.000 & & 0.000 & 0.000 & & 0.085 & 0.117 & 0.728 \\
\hline USA & 0.020 & 0.041 & 0.494 & 0.000 & 0.000 & .. & 0.005 & 0.005 & 1.012 & 0.001 & 0.003 & 0.391 & 0.000 & 0.000 & .. & 0.041 & 0.075 & 0.545 \\
\hline $\begin{array}{l}\text { OECD } \\
\text { average }\end{array}$ & 0.044 & 0.118 & 0.471 & 0.008 & 0.017 & 0.451 & 0.016 & 0.031 & 0.569 & 0.011 & 0.021 & 0.504 & 0.003 & 0.004 & 0.805 & 0.079 & 0.179 & 0.480 \\
\hline
\end{tabular}

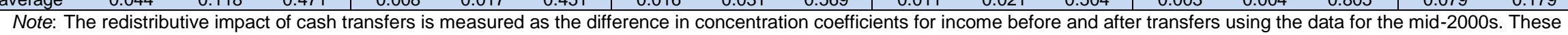

concentration coefficients are both calculated with households ranked by their disposable income. The redistributive impact of transfers between a size and progressivity component is

explained in Box 3. The OECD average is not weighted.

Source: OECD Income Distribution and Poverty Database. 
Table A2.2. Which taxes and transfers are progressive/regressive? Numerical examples

ECO/WKP(2012)3

\begin{tabular}{|c|c|c|c|c|c|c|c|c|c|c|c|c|c|}
\hline Population's deciles & D1 & D2 & D3 & D4 & D5 & D6 & D7 & D8 & D9 & D10 & $\begin{array}{l}\text { Concent- } \\
\text { ration } \\
\text { coefficient }\end{array}$ & $\begin{array}{l}\text { Redist- } \\
\text { ributive } \\
\text { impact }\end{array}$ & Kakwani \\
\hline Income before tax & 10 & 20 & 30 & 40 & 50 & 60 & 70 & 80 & 90 & 100 & 0.300 & & \\
\hline \multicolumn{14}{|l|}{ Taxes (from most progressive to most regressive) } \\
\hline $\begin{array}{l}\text { 1. Relative and absolute progressivity (e.g. PIT) } \\
\text { (as \% of pre-tax income) }\end{array}$ & $\begin{array}{c}1 \\
10 \%\end{array}$ & $\begin{array}{l}3 \\
15 \%\end{array}$ & $\begin{array}{c}6 \\
20 \%\end{array}$ & $\begin{array}{c}10 \\
25 \%\end{array}$ & $\begin{array}{c}15 \\
30 \%\end{array}$ & $\begin{array}{l}21 \\
35 \%\end{array}$ & $\begin{array}{l}28 \\
40 \%\end{array}$ & $\begin{array}{l}36 \\
45 \%\end{array}$ & $\begin{array}{c}45 \\
50 \%\end{array}$ & $\begin{array}{c}55 \\
55 \%\end{array}$ & 0.450 & -0.100 & 0.150 \\
\hline Income after tax & 9.0 & 17.0 & 24.0 & 30.0 & 35.0 & 39.0 & 42.0 & 44.0 & 45.0 & 45.0 & 0.200 & & \\
\hline $\begin{array}{l}\text { 2. Relative neutral but absolute progressivity - flat tax rate } \\
\text { (e.g. social security contributions) }\end{array}$ & 1 & 2 & 3 & 4 & 5 & 6 & 7 & 8 & 9 & 10 & 0.300 & 0.000 & 0.000 \\
\hline (as \% of pre-tax income) & $10 \%$ & $10 \%$ & $10 \%$ & $10 \%$ & $10 \%$ & $10 \%$ & $10 \%$ & $10 \%$ & $10 \%$ & $10 \%$ & & & \\
\hline Income after tax & 9.0 & 18.0 & 27.0 & 36.0 & 45.0 & 54.0 & 63.0 & 72.0 & 81.0 & 90.0 & 0.300 & & \\
\hline $\begin{array}{l}\text { 3. Relative regressivity but absolute progressivity } \\
\text { (e.g. consumption and property taxes) }\end{array}$ & 5.5 & 6 & 6.5 & 7 & 7.5 & 8 & 8.5 & 9 & 9.5 & 10 & 0.106 & 0.032 & -0.194 \\
\hline $\begin{array}{l}\text { (as \% of pre-tax income) } \\
\text { Income after tax }\end{array}$ & $\begin{array}{l}55 \% \\
4.5\end{array}$ & $\begin{array}{l}30 \% \\
14.0\end{array}$ & $\begin{array}{l}22 \% \\
235\end{array}$ & $\begin{array}{l}18 \% \\
33.0\end{array}$ & $\begin{array}{l}15 \% \\
42.5\end{array}$ & $\begin{array}{l}13 \% \\
520\end{array}$ & $\begin{array}{l}12 \% \\
615\end{array}$ & $11 \%$ & $\begin{array}{l}11 \% \\
80,5\end{array}$ & $10 \%$ & 0332 & & \\
\hline $\begin{array}{l}\text { 4. Relative regressivity and absolute neutral - flat amount } \\
\text { (e.g. Poll tax) }\end{array}$ & $\begin{array}{l}4.0 \\
5\end{array}$ & 5 & 5 & 5 & 5 & 5 & 5 & 5 & $\begin{array}{c}80.3 \\
5\end{array}$ & 5 & 0.000 & 0.030 & -0.300 \\
\hline (as \% of pre-tax income) & $50 \%$ & $25 \%$ & $17 \%$ & $13 \%$ & $10 \%$ & $8 \%$ & $7 \%$ & $6 \%$ & $6 \%$ & $5 \%$ & & & \\
\hline Income after tax & 5.0 & 15.0 & 25.0 & 35.0 & 45.0 & 55.0 & 65.0 & 75.0 & 85.0 & 95.0 & 0.330 & & \\
\hline 5. Relative and absolute regressivity & 10 & 9.5 & 9 & 8.5 & 8 & 8 & 7.5 & 7 & 6.5 & 6 & -0.088 & 0.066 & -0.388 \\
\hline (as \% of pre-tax income) & $100 \%$ & $48 \%$ & $30 \%$ & $21 \%$ & $16 \%$ & $13 \%$ & $11 \%$ & $9 \%$ & $7 \%$ & $6 \%$ & & & \\
\hline Income after tax & 0.0 & 10.5 & 21.0 & 31.5 & 42.0 & 52.0 & 62.5 & 73.0 & 83.5 & 94.0 & 0.366 & & \\
\hline \multicolumn{14}{|l|}{ Transfers (from most progressive to most regressive) } \\
\hline $\begin{array}{l}\text { 6. Absolute and relative progressivity (e.g. targeted in-work } \\
\text { benefits) }\end{array}$ & 10 & 9.5 & 9 & 8.5 & 8 & 7.5 & 7 & 6.5 & 6 & 5.5 & -0.106 & -0.050 & -0.406 \\
\hline $\begin{array}{l}\text { (as \% of pre-tax income) } \\
\text { Income after transfers }\end{array}$ & $\begin{array}{l}100 \% \\
20\end{array}$ & $\begin{array}{l}48 \% \\
29.5\end{array}$ & $\begin{array}{c}30 \% \\
39\end{array}$ & $\begin{array}{l}21 \% \\
48.5\end{array}$ & $\begin{array}{c}16 \% \\
58\end{array}$ & $\begin{array}{l}13 \% \\
67.5\end{array}$ & $\begin{array}{l}10 \% \\
77\end{array}$ & $\begin{array}{r}8 \% \\
86.5\end{array}$ & $\begin{array}{l}7 \% \\
96\end{array}$ & $\begin{array}{c}6 \% \\
105.5\end{array}$ & 0.250 & & \\
\hline $\begin{array}{l}\text { 7. Absolute neutral but relative progressivity - Flat benefit } \\
\text { (e.g. minimum pensions) }\end{array}$ & 10 & 10 & 10 & $\begin{array}{c}40.0 \\
10\end{array}$ & 10 & 10 & 10 & 10 & 10 & 10 & 0.000 & -0.046 & -0.300 \\
\hline $\begin{array}{l}\text { (as \% of pre-tax income) } \\
\text { Income after transfers }\end{array}$ & $\begin{array}{c}100 \% \\
20\end{array}$ & $\begin{array}{c}50 \% \\
30\end{array}$ & $\begin{array}{c}33 \% \\
40\end{array}$ & $\begin{array}{l}25 \% \\
50\end{array}$ & $\begin{array}{c}20 \% \\
60\end{array}$ & $\begin{array}{l}17 \% \\
70\end{array}$ & $\begin{array}{l}14 \% \\
80\end{array}$ & $13 \%$ & $11 \%$ & $10 \%$ & & & \\
\hline $\begin{array}{l}\text { Income after transfers } \\
\text { 8. Absolute regressivity and relative progressivity } \\
\text { (e.g. occupational pensions with a declining replacement rate) }\end{array}$ & $\begin{array}{l}20 \\
5.5\end{array}$ & $\begin{array}{c}30 \\
6\end{array}$ & $\begin{array}{l}40 \\
6.5\end{array}$ & $\begin{array}{c}50 \\
7\end{array}$ & $\begin{array}{l}60 \\
7.5\end{array}$ & $\begin{array}{c}70 \\
8\end{array}$ & $\begin{array}{l}80 \\
8.5\end{array}$ & $\begin{array}{c}90 \\
9\end{array}$ & $\begin{array}{l}100 \\
9.5\end{array}$ & $\begin{array}{c}110 \\
10\end{array}$ & $\begin{array}{l}0.254 \\
0.106\end{array}$ & -0.024 & -0.194 \\
\hline $\begin{array}{l}\text { (as \% of pre-tax income) } \\
\text { Income after transfers }\end{array}$ & $\begin{array}{l}55 \% \\
15.5\end{array}$ & $\begin{array}{c}30 \% \\
26\end{array}$ & $\begin{array}{l}22 \% \\
36.5\end{array}$ & $\begin{array}{c}18 \% \\
47\end{array}$ & $\begin{array}{l}15 \% \\
57.5\end{array}$ & $\begin{array}{l}13 \% \\
68\end{array}$ & $\begin{array}{l}12 \% \\
78.5\end{array}$ & $\begin{array}{c}11 \% \\
89\end{array}$ & $\begin{array}{l}11 \% \\
995\end{array}$ & $\begin{array}{l}10 \% \\
110\end{array}$ & 0.276 & & \\
\hline $\begin{array}{l}\text { 9. Absolute regressivity but relative neutral (e.g. occupational } \\
\text { pensions with a constant replacement rate) }\end{array}$ & 1 & 2 & 3 & 4 & 5 & 6 & 7 & 8 & 9 & 10 & 0.300 & 0.000 & 0.000 \\
\hline (as \% of pre-tax income) & $10 \%$ & $10 \%$ & $10 \%$ & $10 \%$ & $10 \%$ & $10 \%$ & $10 \%$ & $10 \%$ & $10 \%$ & $10 \%$ & & & \\
\hline Income after transfers & 11 & 22 & 33 & 44 & 55 & 66 & 77 & 88 & 99 & 110 & 0.300 & & \\
\hline $\begin{array}{l}\text { 10. Relative and absolute regressivity (e.g. child care benefits } \\
\text { based on actual spending or spending on tertiary education) }\end{array}$ & 1 & 3 & 6 & 10 & 15 & 21 & 28 & 36 & 45 & 55 & 0.450 & 0.043 & 0.150 \\
\hline $\begin{array}{l}\text { (as \% of pre-tax income) } \\
\text { Income after transfers }\end{array}$ & $\begin{array}{l}10 \% \\
11\end{array}$ & $\begin{array}{l}15 \% \\
23\end{array}$ & $\begin{array}{c}20 \% \\
36\end{array}$ & $\begin{array}{c}25 \% \\
50\end{array}$ & $\begin{array}{c}30 \% \\
65\end{array}$ & $\begin{array}{c}35 \% \\
81\end{array}$ & $\begin{array}{c}40 \% \\
98\end{array}$ & $\begin{array}{c}45 \% \\
116\end{array}$ & $\begin{array}{c}50 \% \\
135\end{array}$ & $\begin{array}{c}55 \% \\
155\end{array}$ & 0.343 & & \\
\hline
\end{tabular}


Table A2.3. Unemployment insurance benefits

2007, for a 40-year old (where benefits are conditional on work history, assuming a long and uninterrupted employment record)

\begin{tabular}{|c|c|c|c|c|c|c|c|c|c|c|}
\hline & $\begin{array}{l}\text { Employment (E) } \\
\text { and contribution (C) } \\
\text { conditions }\end{array}$ & $\begin{array}{l}\text { Voluntary (V) or } \\
\text { compulsory (C) } \\
\text { contributions }\end{array}$ & $\begin{array}{l}\text { Waiting } \\
\text { period } \\
\text { (days) }\end{array}$ & $\begin{array}{c}\text { Maximum } \\
\text { duration } \\
\text { (months) }^{1}\end{array}$ & $\begin{array}{c}\text { Payment rate } \\
\text { (\% of earnings base } \\
\text { at end of legal } \\
\text { entitlement period) })^{1}\end{array}$ & $\begin{array}{l}\text { Earnings } \\
\text { base }^{2}\end{array}$ & $\begin{array}{c}\text { Min. } \\
\text { benefit } \\
(\% \text { of } \\
\text { AW) })^{1} \\
\end{array}$ & $\begin{array}{c}\text { Max } \\
\text { benefit } \\
(\% \text { of } \\
\text { AW) })^{1} \\
\end{array}$ & $\begin{array}{l}\text { Permitted employment } \\
\text { and disregards }\end{array}$ & $\begin{array}{l}\text { Additions for } \\
\text { dependent family } \\
\text { members }\end{array}$ \\
\hline & (1) & (2) & (3) & (4) & (5) & (6) & (7) & (8) & (9) & (10) \\
\hline Austria & $E+C: 1$ year in 2. & $\begin{array}{l}\mathrm{C} \text { (if earnings } \\
\text { above threshold) }\end{array}$ & 0 & 9 & 55 & Net & -- & 39 & $\begin{array}{l}\text { No reduction up to } € 4093.92, \\
\text { total loss above. Exception: } \\
\text { benefit reduced when } \\
<27 \text { days/month and net earning } \\
\text { less than benefit. }\end{array}$ & $\begin{array}{l}\text { Each dependant: } \\
\text { EUR } 354 .\end{array}$ \\
\hline Belgium & $\begin{array}{l}\text { E+C: } 468 \text { days in } \\
27 \text { months. }\end{array}$ & C & 0 & Unlimited & $\begin{array}{c}60[50 \text { (after one } \\
\text { year)] }\end{array}$ & Gross & 24 & 33 & $\begin{array}{l}\text { Maximum: limit of } € 3647 \text { for } \\
\text { artistic employment. }\end{array}$ & $\begin{array}{l}\text { If dependants, } \\
\text { minimum benefit is } \\
\text { increased to } \\
€ 10951 \text {. }\end{array}$ \\
\hline Canada $^{3}$ & $\begin{array}{l}\mathrm{E}+\mathrm{C}: 700 \text { hours in } \\
1 \text { year. }\end{array}$ & C & 14 & 8 & 55 & Gross & -- & 50 & $\begin{array}{l}\text { Up to } 25 \% \text { of benefits or CAD } \\
2600 \text {, whichever is higher. }\end{array}$ & $\begin{array}{l}\text { Family supplements } \\
\text { depend on income } \\
\text { plus age and number } \\
\text { of children. }\end{array}$ \\
\hline $\begin{array}{l}\text { Czech } \\
\text { Republic }\end{array}$ & $\begin{array}{l}E+C: 12 \text { months in } \\
3 \text { years. }\end{array}$ & C & -- & 6 & $\begin{array}{l}50[45 \text { (after three } \\
\text { months) })\end{array}$ & Net & -- & 58 & $\begin{array}{l}\text { Half of the minimum wage in a } \\
\text { month is allowed without losing } \\
\text { the entitlement to unemployment } \\
\text { benefits. }\end{array}$ & -- \\
\hline Denmark & $\begin{array}{l}\text { E: } 52 \text { weeks in } \\
3 \text { years, } \\
\text { C: membership fee. }\end{array}$ & V & 0 & 48 & 90 & $\begin{array}{l}\text { Gross less } \\
8 \% \text { SSC. }\end{array}$ & 42 & 51 & $\begin{array}{l}\text { Benefits are reduced in proportion } \\
\text { to hours worked. }\end{array}$ & -- \\
\hline Finland & $\begin{array}{l}\text { E: } 43 \text { weeks in } \\
28 \text { months, } \\
\text { C: } 10 \text { months. }\end{array}$ & V & 7 & 23 & $\begin{array}{l}\text { Basic benefit ( } 17 \% \text { of } \\
\text { AW) plus up to } 45 \% \\
\text { of earnings } \\
\text { exceeding basic } \\
\text { benefit. }\end{array}$ & $\begin{array}{l}\text { Gross } \\
\text { (excluding } \\
\text { additional } \\
\text { holiday pay) } \\
\text { less SSC. }\end{array}$ & -- & None & $\begin{array}{l}\text { Working hours }<75 \% \text { of full time. } \\
\text { Benefit reduced by } 50 \% \text { of gross } \\
\text { income. Benefit plus income } \\
<90 \% \text { of reference earnings. }\end{array}$ & $\begin{array}{l}\text { Supplements: } \\
€ 1169,1716,2214 \\
\text { for } 1,2 \text { and } 3 \text { or } \\
\text { more children } \\
\text { respectively. }\end{array}$ \\
\hline France & C: 6 months in 22. & C & 8 & 23 & $57-75$ & Gross & 30 & 240 & $\begin{array}{l}\text { Income }<70 \% \text { of reference } \\
\text { earnings, hours worked/month } \\
<110 \text { and duration }<15 \text { months. } \\
\text { Benefit reduced depending on } \\
\text { income ratio to reference } \\
\text { earnings. }\end{array}$ & -- \\
\hline Germany & $\begin{array}{l}\text { E: } 12 \text { months, } \\
\text { C: } 12 \text { months in } 3 \\
\text { years. }\end{array}$ & C & 0 & 12 & 60 & Net & -- & 94 & $\begin{array}{l}\text { Total loss if working more than } \\
15 \text { hours/week. }\end{array}$ & $\begin{array}{l}\text { Rate increases by } \\
7 \text { percentage points if } \\
\text { children. }\end{array}$ \\
\hline Greece & $\begin{array}{l}\mathrm{E}+\mathrm{C}: 125 \text { days in } \\
14 \text { months or } 200 \\
\text { days in } 2 \text { years. }\end{array}$ & C & 6 & 12 & $\begin{array}{l}\text { Basic benefit } \\
(19 \% \text { of } A W) \text {. }\end{array}$ & Gross & -- & -- & $\begin{array}{l}\text { Benefit may be combined with a } \\
\text { part time employment if earnings } \\
\text { less than approved amount of } \\
\text { benefit }\end{array}$ & $\begin{array}{l}\text { Benefit increased by } \\
10 \% \text { for each. }\end{array}$ \\
\hline Hungary & $\begin{array}{l}E+C: 365 \text { days in } \\
4 \text { years. }\end{array}$ & C & 0 & 9 & 60 & $\begin{array}{l}\text { Average gross } \\
\text { average } \\
\text { earnings of last } \\
4 \text { quarters. }\end{array}$ & 22 & 44 & $\begin{array}{l}\text { For short term (<90 days) } \\
\text { employment benefit is } \\
\text { suspended. For "employment } \\
\text { booklet" programme the benefit is } \\
\text { reduced by amount earned. }\end{array}$ & -- \\
\hline
\end{tabular}


Table A2.3. Unemployment insurance benefits, continued

ECO/WKP(2012)3

\begin{tabular}{|c|c|c|c|c|c|c|c|c|c|c|}
\hline & $\begin{array}{l}\text { Employment }(E) \\
\text { and contribution }(C) \\
\text { conditions }\end{array}$ & $\begin{array}{l}\text { Voluntary }(\mathrm{V}) \text { or } \\
\text { compulsory (C) } \\
\text { contributions }\end{array}$ & $\begin{array}{l}\text { Waiting } \\
\text { period } \\
\text { (days) }\end{array}$ & $\begin{array}{l}\text { Maximum } \\
\text { duration } \\
\text { (months) }^{1}\end{array}$ & $\begin{array}{c}\text { Payment rate } \\
\text { (\% of earnings base } \\
\text { at end of legal } \\
\text { entitlement period) })^{1}\end{array}$ & $\begin{array}{l}\text { Earnings } \\
\text { base }^{2}\end{array}$ & $\begin{array}{c}\text { Min. } \\
\text { benefit } \\
\text { (\% of } \\
\text { AW) })^{1} \\
\end{array}$ & $\begin{array}{c}\text { Max } \\
\text { benefit } \\
\text { (\% of } \\
\text { AW) })^{1} \\
\end{array}$ & $\begin{array}{l}\text { Permitted employment } \\
\text { and disregards }\end{array}$ & $\begin{array}{l}\text { Additions for } \\
\text { dependent family } \\
\text { members }\end{array}$ \\
\hline & (1) & (2) & (3) & (4) & (5) & (6) & (7) & (8) & (9) & (10) \\
\hline Iceland & $\mathrm{E}+\mathrm{C}: 10$ weeks. & $\mathrm{C}$ & 0 & 36 & $\begin{array}{l}\text { Fixed amount } \\
\text { ( } 36 \% \text { of } A W) \text {. }\end{array}$ & $\begin{array}{l}\text { In proportion } \\
\text { to number of } \\
\text { hours worked } \\
\text { in previous } \\
12 \text { months }\end{array}$ & -- & -- & $\begin{array}{l}\text { For occasional employment } \\
<2 \text { days, benefit is reduced } \\
\text { proportionally. }\end{array}$ & ISK 65260 per child. \\
\hline Ireland $^{4}$ & $\begin{array}{l}\text { C: } 39 \text { weeks in } 1 \text { year } \\
\text { (or } 26 \text { "reckonable" } \\
\text { contributions in } \\
2 \text { years). } 52 \text { weeks } \\
\text { contributions paid } \\
\text { since starting work }\end{array}$ & C & 3 & 15 & $\begin{array}{l}\text { Fixed amount } \\
\text { ( } 24 \% \text { of } A W) \text {. }\end{array}$ & -- & -- & -- & $\begin{array}{l}\text { Benefit is not paid for any day or } \\
\text { partial day of employment. } \\
\text { Earnings are not assessed. }\end{array}$ & $\begin{array}{l}\text { Supplements of } \\
€ 1144 \text { per child, } \\
€ 6412 \text { per adult. }\end{array}$ \\
\hline Italy ${ }^{5}$ & $\begin{array}{l}\text { C: } 52 \text { weeks in } \\
2 \text { years. }\end{array}$ & C & 7 & 7 & $\begin{array}{l}50[40 \text { (after six } \\
\text { months)] }\end{array}$ & $\begin{array}{l}\text { Average } \\
\text { gross } \\
\text { earnings of } \\
\text { last } 3 \text { months. }\end{array}$ & -- & 48 & $\begin{array}{l}\text { No benefits if receiving earnings } \\
\text { from employment except for CIG } \\
\text { scheme. }\end{array}$ & -- \\
\hline Japan & $\begin{array}{l}E+C: 6 \text { months in } \\
1 \text { year (at least } \\
14 \text { days each } \\
\text { month). }\end{array}$ & C & 7 & 9 & $50-80$ & $\begin{array}{l}\text { Gross } \\
\text { earnings of } \\
\text { last } 6 \text { months } \\
\text { (excl. } \\
\text { bonuses). }\end{array}$ & -- & 51 & No benefits if employed. & -- \\
\hline Korea & $\mathrm{E}+\mathrm{C}: 6$ months in 18 & C & 14 & 7 & 50 & $\begin{array}{l}\text { Gross } \\
\text { earnings of } \\
\text { last } 3 \text { months. }\end{array}$ & 23 & 45 & $\begin{array}{l}\text { If income divided by number of } \\
\text { benefit days entitled is over } 60 \% \text { of } \\
\text { Ul benefit then excess deducted. }\end{array}$ & -- \\
\hline Luxembourg & $\begin{array}{l}\mathrm{E}+\mathrm{C}: 26 \text { weeks in } \\
1 \text { year. }\end{array}$ & c & 0 & 12 & 80 & Gross & -- & 94 & $\begin{array}{l}\text { Reduced if earnings }>10 \% \text { of } \\
\text { maximum benefit due. }\end{array}$ & $\begin{array}{l}\text { Rate increases by } \\
5 \text { percentage points if } \\
\text { children. }\end{array}$ \\
\hline Netherlands & $\begin{array}{l}\text { E: } 26 \text { weeks in } 36, \\
\text { C: } 52 \text { days in } 4 \text { of } \\
5 \text { years. }\end{array}$ & c & 0 & 38 & $\begin{array}{l}75 \text { [70 (after } \\
2 \text { months)] }\end{array}$ & Gross & 36 & 111 & $\begin{array}{l}\text { If }<5 \text { hours/week, benefit reduced } \\
\text { by } 70 \% \text { of gross earnings. If } \\
>5 \text { hours/week, proportional } \\
\text { reduction. }\end{array}$ & $\begin{array}{l}\text { Supplementary } \\
\text { benefits for low- } \\
\text { income households } \\
\text { to bring income up to } \\
\text { a minimum } \\
\text { guaranteed level. }\end{array}$ \\
\hline Norway & $\begin{array}{l}\mathrm{E}+\mathrm{C} \text { : Earnings above } \\
\text { a minimum level. }\end{array}$ & C & -- & 24 & 62.4 & Gross & 15 & 59 & -- & NOK 4420 per child. \\
\hline Poland & $\begin{array}{l}\mathrm{E}+\mathrm{C}: 365 \text { days in } 18 \\
\text { months and earnings } \\
>1 / 2 \text { minimum wage. }\end{array}$ & c & 7 & 12 & $\begin{array}{l}\text { Fixed amount } \\
(24 \% \text { of } A W){ }^{7}\end{array}$ & -- & -- & -- & $\begin{array}{l}\text { Gross income disregard of up to } \\
\text { PLN } 5616 \text { (half the minimum } \\
\text { pay). }\end{array}$ & -- \\
\hline Portugal & $\begin{array}{l}\mathrm{E}+\mathrm{C}: 270 \text { days in } \\
12 \text { months. }\end{array}$ & C & 0 & 24 & 65 & Gross & 29 & 88 & $\begin{array}{l}\text { If income }<\text { Ul benefit and hours } \\
<75 \% \text { of previous working hours, } \\
\text { then UI benefit = (UI benefit - } \\
\text { income) }{ }^{*} 1.35\end{array}$ & -- \\
\hline $\begin{array}{l}\text { Slovak } \\
\text { Republic }\end{array}$ & $\begin{array}{l}E+C: 3 \text { years in } \\
4 \text { years. }\end{array}$ & C & 0 & 6 & 50 & Gross & -- & -- & -- & -- \\
\hline Spain & $\begin{array}{l}\text { C: } 360 \text { days in } \\
6 \text { years. }\end{array}$ & c & 0 & 24 & $\begin{array}{l}70[60 \text { (after six } \\
\text { months)] }\end{array}$ & Gross & 26 & 56 & $\begin{array}{l}\text { Benefits are reduced in proportion } \\
\text { to hours worked. }\end{array}$ & $\begin{array}{l}\text { Increased minima } \\
\text { and maxima if } \\
\text { children. }\end{array}$ \\
\hline
\end{tabular}


ECO/WKP(2012)3

Table A2.3. Unemployment insurance benefits, continued

\begin{tabular}{|c|c|c|c|c|c|c|c|c|c|c|}
\hline & $\begin{array}{l}\text { Employment (E) } \\
\text { and contribution (C) } \\
\text { conditions }\end{array}$ & $\begin{array}{l}\text { Voluntary (V) or } \\
\text { compulsory (C) } \\
\text { contributions }\end{array}$ & $\begin{array}{l}\text { Waiting } \\
\text { period } \\
\text { (days) }\end{array}$ & $\begin{array}{c}\text { Maximum } \\
\text { duration } \\
\text { (months) }^{1}\end{array}$ & $\begin{array}{c}\text { Payment rate } \\
\text { (\% of earnings base } \\
\text { at end of legal } \\
\text { entitlement period) }{ }^{1}\end{array}$ & $\begin{array}{c}\text { Earnings } \\
\text { base }^{2}\end{array}$ & $\begin{array}{c}\text { Min. } \\
\text { benefit } \\
(\% \text { of } \\
\text { AW) })^{1}\end{array}$ & $\begin{array}{c}\text { Max } \\
\text { benefit } \\
(\% \text { of } \\
\text { AW })^{1}\end{array}$ & $\begin{array}{l}\text { Permitted employment } \\
\text { and disregards }\end{array}$ & $\begin{array}{l}\text { Additions for } \\
\text { dependent family } \\
\text { members }\end{array}$ \\
\hline & (1) & (2) & (3) & (4) & (5) & (6) & (7) & (8) & (9) & (10) \\
\hline Sweden & $\begin{array}{l}\text { E: } 6 \text { months in last } \\
\text { year, } C: 12 \text { months. }\end{array}$ & $\mathrm{V}$ & 5 & 14 & $\begin{array}{l}80[70 \text { (after } \\
200 \text { days)] }\end{array}$ & Gross & 25 & 52 & $\begin{array}{l}\text { Benefits are reduced in proportion } \\
\text { to days worked. }\end{array}$ & -- \\
\hline Switzerland & $\begin{array}{l}E+C: 12 \text { months in } \\
2 \text { years. }\end{array}$ & C & 5 & 18 & 70 & Gross & -- & 101 & $\begin{array}{l}\text { "Compensation payment for } \\
\text { intermediate earnings": benefits } \\
\text { are equal to } 70 \% \text { of the difference } \\
\text { between insured earnings and } \\
\text { current earnings. }\end{array}$ & $\begin{array}{l}\text { Rate increases by } \\
10 \text { percentage points } \\
\text { if children or low } \\
\text { income. }\end{array}$ \\
\hline Turkey & $\begin{array}{l}\text { E: } 600 \text { days in } 3 \\
\text { years, } \mathrm{C}: 120 \text { days } \\
\text { continuously. }\end{array}$ & C & 0 & 10 & 50 & Net & 14 & 29 & No benefits if employed. & -- \\
\hline $\begin{array}{l}\text { United } \\
\text { Kingdom }\end{array}$ & $\begin{array}{l}\text { C: } 12 \text { months in } \\
2 \text { years. }\end{array}$ & C & 3 & 6 & $\begin{array}{l}\text { Fixed amount } \\
\text { ( } 9 \% \text { of } A W) .\end{array}$ & -- & -- & -- & $\begin{array}{l}\text { Income > GBP } 260 \text { ( } 520 \text { for } \\
\text { couples) reduces benefit by same } \\
\text { amount. }\end{array}$ & -- \\
\hline $\begin{array}{l}\text { United } \\
\text { States }\end{array}$ & $\begin{array}{l}\mathrm{E}: 20 \text { weeks (plus } \\
\text { minimum earnings } \\
\text { requirement). }\end{array}$ & C & 0 & 6 & 53.3 & Gross & 11 & 48 & $\begin{array}{l}\text { Earnings less than gross benefit } \\
\text { are deducted at } 50 \% \text { rate; } \\
\text { Earnings exceeding gross benefit } \\
\text { are subtracted from } 1.5 \text { times the } \\
\text { gross benefit amount. Individuals } \\
\text { earning more than } 1.5 \text { times their } \\
\text { gross benefit amount are } \\
\text { ineligible. }\end{array}$ & $\begin{array}{l}\text { USD } 312 \text { for each } \\
\text { dependant. }\end{array}$ \\
\hline
\end{tabular}

. Single worker without children, benefits may differ depending on family situation. All benefit amounts are shown on an annualised basis. "--" indicates that no information is available or not applicable.

Gross = gross employment income; SSC = (employee) social security contributions; Net = Gross minus income taxes minus SSC.

3. The duration of Employment Insurance (EI) payments depends on the unemployment rate in the relevant El region. The 36 week duration shown here relates to an unemployment rate of $6 \%$ in Ontario.

. Where weekly earnings while in employment were below certain amounts, reduced rates of payment are made. If dependent adult is employed, supplement is reduced or suppressed depending on income level.

For employees with a temporary reduction of working hours there is also the CIG (Cassa Integrazione Guadagni) scheme which pays benefits of $80 \%$ of average gross earnings for non-worked hours

7. At least $24 \%$ of

A

Source: OECD (2007), Unemployment benefits (unemployment insurance, unemployment assistance), http://www.oecd.org/document/3/0,3746,en_2649_33933_39617987_1_1_1_1,00.htm/ 
ECO/WKP(2012)3

Table A2.4. Progressivity of unemployment benefits net of taxes

Measured by the difference in net replacement rates between low and high income earners ${ }^{1}$

2009, initial phase of unemployment

\begin{tabular}{|c|c|c|c|c|c|c|}
\hline & \multicolumn{3}{|c|}{ No children } & \multicolumn{3}{|c|}{2 children } \\
\hline & $\begin{array}{l}\text { Single } \\
\text { person }\end{array}$ & $\begin{array}{l}\text { One-earner } \\
\text { married couple }\end{array}$ & $\begin{array}{c}\text { Two-earner } \\
\text { married } \\
\text { couple }\end{array}$ & $\begin{array}{l}\text { Lone } \\
\text { parent }\end{array}$ & $\begin{array}{l}\text { One-earner } \\
\text { married couple }\end{array}$ & $\begin{array}{c}\text { Two-earner } \\
\text { married } \\
\text { couple }\end{array}$ \\
\hline Slovak Republic & -6 & -3 & 4 & -9 & -2 & 4 \\
\hline Portugal & -4 & -1 & 3 & -3 & 1 & 3 \\
\hline France & 1 & 5 & 7 & 14 & 15 & 6 \\
\hline Estonia & 1 & 2 & 9 & 5 & -1 & 10 \\
\hline Germany & 3 & 7 & 9 & 17 & 14 & 7 \\
\hline Luxembourg & 6 & 7 & 7 & 8 & 12 & 9 \\
\hline Switzerland & 9 & 12 & 9 & 2 & 2 & 3 \\
\hline Austria & 12 & 13 & 16 & 20 & 21 & 17 \\
\hline$|s r a e|^{2}$ & 16 & 16 & 14 & 7 & 11 & 13 \\
\hline Netherlands & 19 & 29 & 15 & 18 & 22 & 13 \\
\hline Finland & 20 & 28 & 15 & 25 & 26 & 16 \\
\hline Canada & 20 & 19 & 20 & 11 & 12 & 19 \\
\hline Norway & 20 & 20 & 19 & 23 & 37 & 19 \\
\hline Iceland & 21 & 11 & 18 & 19 & 10 & 17 \\
\hline Australia & 21 & 28 & 18 & 18 & 23 & 18 \\
\hline Japan & 21 & 21 & 21 & 25 & 20 & 21 \\
\hline Ireland & 21 & 33 & 23 & 19 & 27 & 22 \\
\hline Korea & 22 & 22 & 22 & 23 & 21 & 24 \\
\hline Czech Republic & 23 & 26 & 17 & 28 & 28 & 20 \\
\hline United States & 23 & 22 & 24 & 17 & 15 & 26 \\
\hline New Zealand & 26 & 32 & 20 & 26 & 27 & 18 \\
\hline Greece & 28 & 30 & 27 & 31 & 34 & 31 \\
\hline United Kingdom & 29 & 34 & 20 & 28 & 28 & 22 \\
\hline Italy & 29 & 28 & 25 & 20 & 18 & 23 \\
\hline Hungary & 30 & 31 & 23 & 28 & 26 & 21 \\
\hline Slovenia & 30 & 31 & 24 & 15 & 17 & 25 \\
\hline Sweden & 33 & 33 & 27 & 32 & 36 & 26 \\
\hline Turkey ${ }^{3}$ & 34 & 33 & 31 & 33 & 32 & 31 \\
\hline Poland & 35 & 37 & 26 & 41 & 27 & 27 \\
\hline Spain & 37 & 33 & 28 & 22 & 22 & 20 \\
\hline Denmark & 38 & 37 & 30 & 26 & 29 & 29 \\
\hline Belgium & 40 & 33 & 25 & 34 & 30 & 24 \\
\hline$O E C D$ & 20.6 & 22.2 & 18.6 & 19.5 & 20.0 & 18.3 \\
\hline Coefficient of variation ${ }^{4}$ & 0.6 & 0.5 & 0.4 & 0.6 & 0.5 & 0.4 \\
\hline
\end{tabular}

1. Progressivity is defined as the difference in the net replacement rate for low and high earners defined as having earnings equal to 67 and $150 \%$ of the average wage. The wider the difference, the more progressive are unemployment benefits. Countries are ordered from the smallest to the largest values in progressivity for a single person. No social assistance "top-ups" are included in either the in-work or out-of-work situation. Any income taxes payable on unemployment benefits are determined in relation to annualised benefit values (i.e. monthly values multiplied by 12) even if the maximum benefit duration is shorter than 12 months. For married couples the second spouse is assumed to be "inactive" in a one-earner couple and to have earnings equal to $67 \%$ of the average wage in a two-earner couple. Children are aged 4 and 6 and neither childcare benefits nor childcare costs are considered.

2. The data for Israel are supplied by and under the responsibility of the relevant Israeli authorities. The use of such data by the OECD is without prejudice to the status of the Golan Heights, East Jerusalem and Israeli settlements in the West Bank under the terms of international law.

3. The average wage is not available. Calculations are based on the average production wage.

4. The coefficient of variation is the standard deviation-to-mean ratio.

Source: OECD, Tax-Benefit Models, www.oecd.org/els/social/workincentives 
Table A2.5. Difference in the long-term unemployment net replacement rates between low and high earners, 2009

Long-term unemployment (5 years)

\begin{tabular}{|c|c|c|c|c|c|c|}
\hline & \multicolumn{3}{|c|}{ No children } & \multicolumn{3}{|c|}{2 children } \\
\hline & $\begin{array}{l}\text { Single } \\
\text { person }\end{array}$ & $\begin{array}{c}\text { One-earner } \\
\text { married } \\
\text { couple } \\
\end{array}$ & $\begin{array}{c}\text { Two-earner } \\
\text { married } \\
\text { couple }\end{array}$ & $\begin{array}{l}\text { Lone } \\
\text { parent }\end{array}$ & $\begin{array}{l}\text { One-earner } \\
\text { married couple }\end{array}$ & $\begin{array}{c}\text { Two-earner } \\
\text { married } \\
\text { couple }\end{array}$ \\
\hline Greece & 0 & 0 & 16 & 5 & 2 & 17 \\
\hline Italy & 0 & 1 & 18 & 0 & 1 & 19 \\
\hline Turkey $^{2}$ & 0 & 0 & 19 & 0 & 0 & 19 \\
\hline United States & 6 & 9 & 19 & 18 & 20 & 22 \\
\hline Austria & 11 & 24 & 15 & 19 & 29 & 9 \\
\hline$|s r a e|^{3}$ & 11 & 16 & 16 & 24 & 23 & 16 \\
\hline Portugal & 12 & 23 & 17 & 23 & 33 & 17 \\
\hline Hungary & 14 & 26 & 14 & 17 & 25 & 15 \\
\hline Korea & 14 & 25 & 18 & 34 & 41 & 18 \\
\hline Slovak Republic & 14 & 23 & 18 & 16 & 30 & 19 \\
\hline Spain & 16 & 20 & 18 & 22 & 23 & 17 \\
\hline Canada & 16 & 24 & 20 & 21 & 23 & 21 \\
\hline Estonia & 17 & 21 & 19 & 21 & 26 & 20 \\
\hline Poland & 18 & 25 & 20 & 29 & 24 & 22 \\
\hline Australia & 21 & 28 & 18 & 13 & 23 & 0 \\
\hline Czech Republic & 23 & 31 & 19 & 28 & 32 & 21 \\
\hline Germany & 24 & 30 & 19 & 35 & 32 & 20 \\
\hline Slovenia & 24 & 32 & 19 & 24 & 27 & 23 \\
\hline France & 25 & 28 & 20 & 31 & 30 & 21 \\
\hline New Zealand & 26 & 32 & 20 & 26 & 27 & 18 \\
\hline Finland & 27 & 38 & 17 & 27 & 36 & 19 \\
\hline Norway & 28 & 38 & 18 & 22 & 46 & 17 \\
\hline Iceland & 28 & 35 & 19 & 26 & 32 & 19 \\
\hline Luxembourg & 29 & 43 & 16 & 25 & 34 & 18 \\
\hline United Kingdom & 29 & 34 & 17 & 28 & 28 & 22 \\
\hline Sweden & 30 & 37 & 16 & 24 & 39 & 16 \\
\hline Ireland & 31 & 46 & 17 & 21 & 34 & 19 \\
\hline Belgium & 31 & 29 & 22 & 31 & 28 & 21 \\
\hline Japan & 33 & 46 & 18 & 41 & 57 & 19 \\
\hline Denmark & 35 & 20 & 23 & 24 & 13 & 27 \\
\hline Netherlands & 36 & 39 & 17 & 22 & 27 & 20 \\
\hline Switzerland & 37 & 46 & 18 & 39 & 43 & 20 \\
\hline$O E C D$ & 20.8 & 27.2 & 18.1 & 23.0 & 27.8 & 18.5 \\
\hline Coefficient of variation ${ }^{4}$ & 0.5 & 0.5 & 0.1 & 0.4 & 0.4 & 0.2 \\
\hline Rank correlation & 0.0 & 0.0 & 0.2 & 0.1 & -0.1 & 0.2 \\
\hline
\end{tabular}

1. Countries are ordered from the smallest to the largest value for a single person. Benefits include unemployment benefits, social assistance, family and housing benefits in the 60th month of benefit receipt. Low and high earners are defined at 67 and $150 \%$ of average wage (AW). For married couples with one-earner, the second spouse is assumed to be "inactive" and for two-earner couples to have earnings equal to $67 \%$ of AW. Children are aged 4 and 6 and neither childcare benefits nor childcare costs are considered.

2. AW value is not available. Calculations are based on APW.

3. The statistical data for Israel are supplied by and under the responsibility of the relevant Israeli authorities. The use of such data by the OECD is without prejudice to the status of the Golan Heights, East Jerusalem and Israeli settlements in the West Bank under the terms of international law.

4. The coefficient of variation is the standard deviation-to-mean ratio.

Source: OECD, Tax-Benefit Models, www.oecd.org/els/social/workincentives 
Figure A2.1. Redistributive impact of household taxes and transfers

Two approaches to calculating the redistributive impact of household taxes and cash transfers

A. Redistributive impact of household taxes and cash transfers

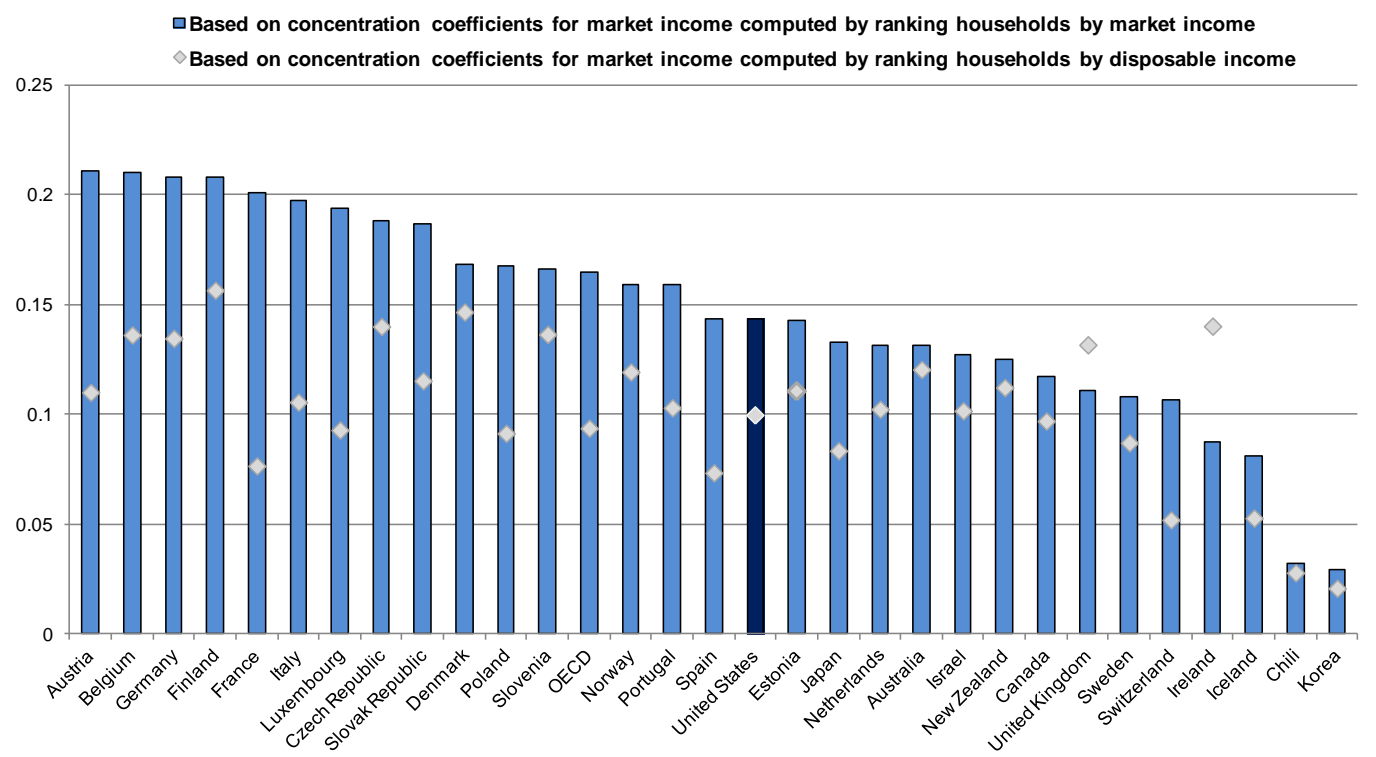

B. Redistributive impact and income inequality before taxes and transfers

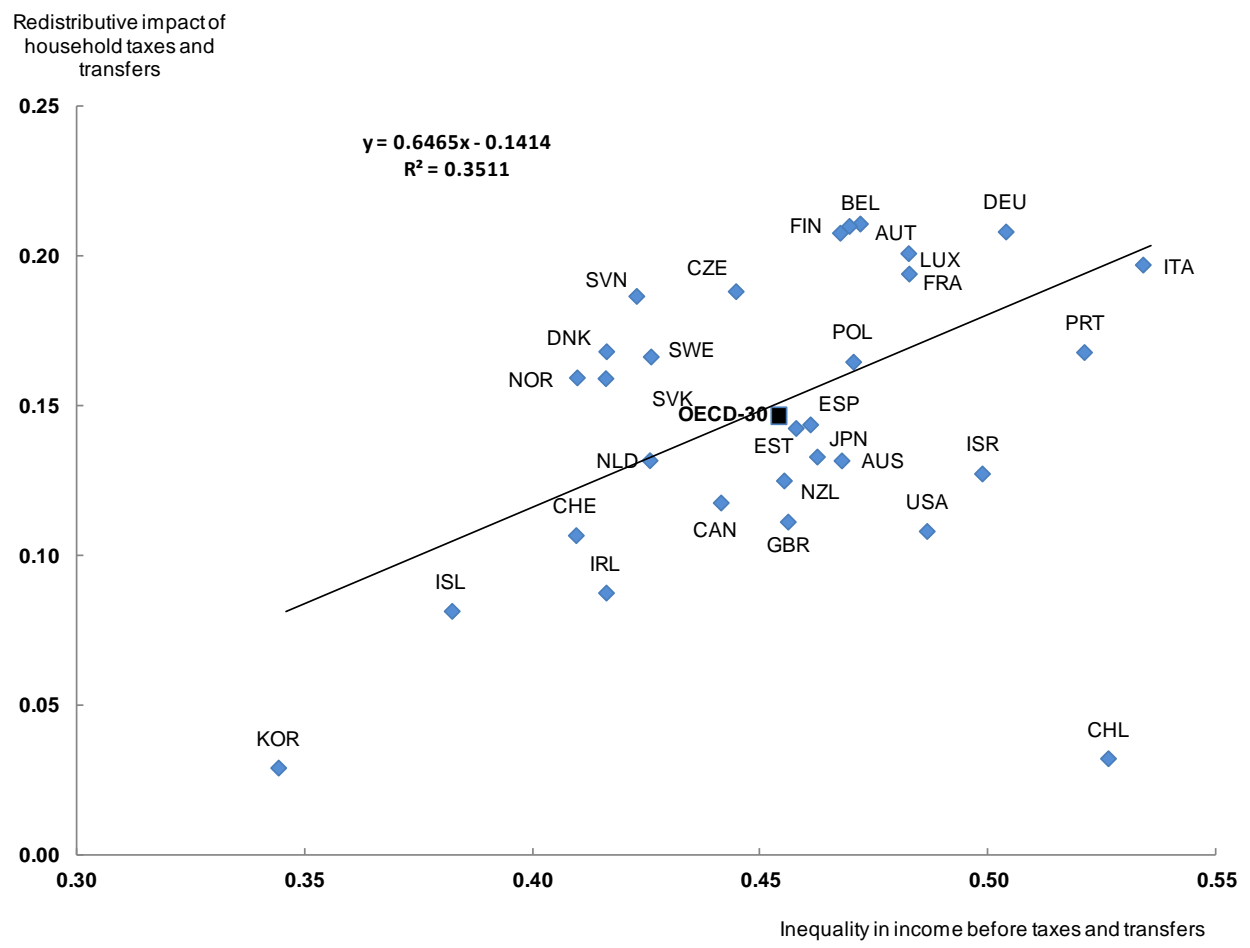

Note: Inequality in income is measured by the concentration coefficient. The redistributive impact of taxes and cash transfers is defined as the difference in concentration coefficients for income before, and after, cash transfers and taxes. Two approaches can be used to measure the concentration of income before taxes and transfers (i.e. market income). One ranks households by market income; the other ranks households by disposable income. In the top panel, the difference between these two approaches can be seen. In the bottom panel, Figure 1 is reproduced using concentration coefficients re-ranked by household market income. Because of data limitations, the second approach, i.e. ranking households by their disposable income, is used elsewhere in this paper. Data for France and Ireland refer to mid-2000s. The trend line shown has been calculated excluding Chile. 
A2.1. Redistributive impact of household taxes and transfers, continued

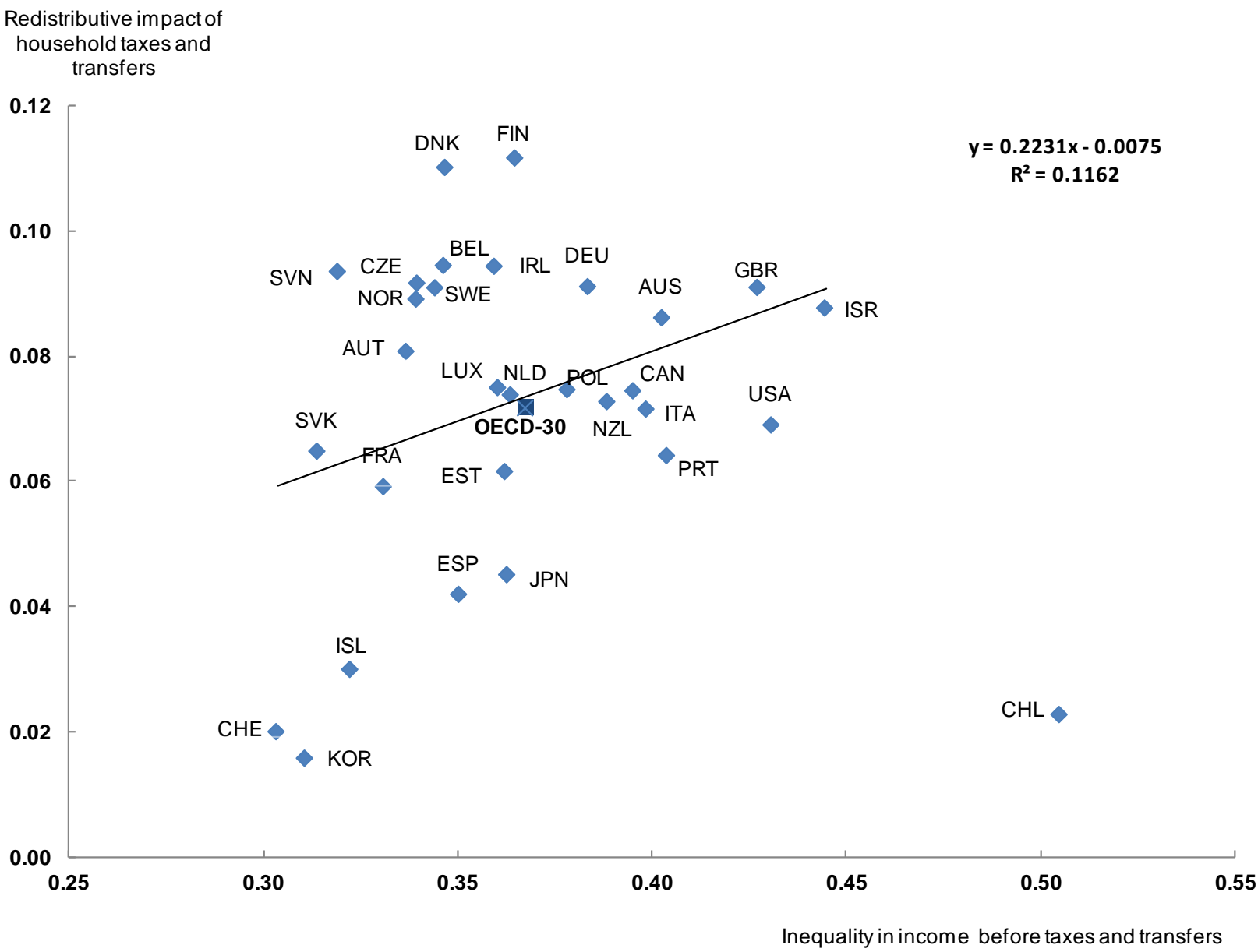

Note: The figure reproduces Figure 1 (in the main text), but focuses on the working-age population instead of total population. Most old-age pensions are thus excluded, and the problem associated with inconsistent treatment of old-age pensions across countries is therefore mitigated. Data for France and Ireland refer to mid-2000s. The trend line shown above has been calculated excluding Chile.

Source: OECD Income Distribution and Poverty Database. 
ECO/WKP(2012)3

\section{Figure A2.2. Impact of pension reforms on progressivity ${ }^{1}$}

2006

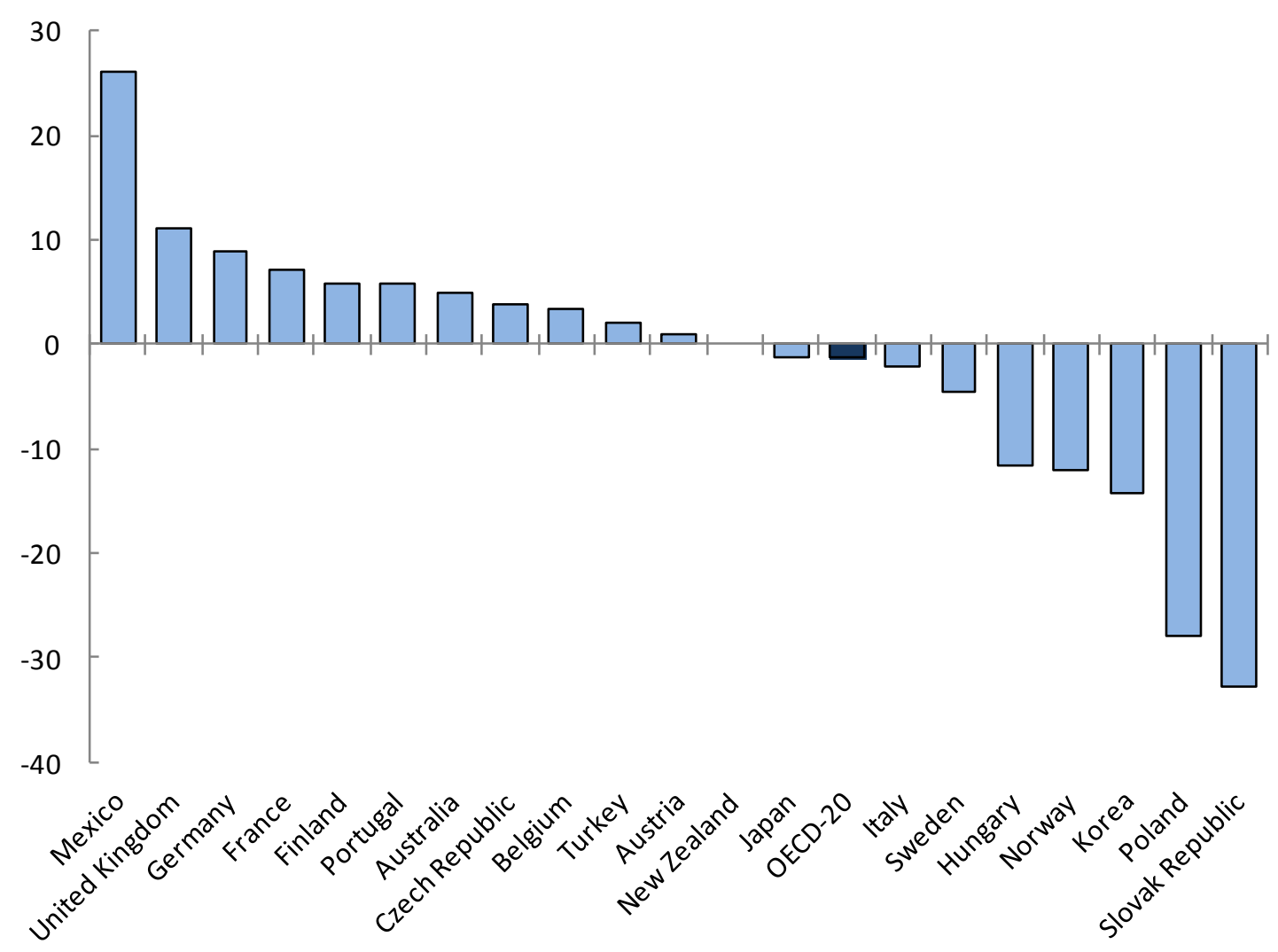

1. Reforms from 1990 are considered here. The bars show the difference in progressivity of mandatory pension schemes under preand post-reform rules. Progressivity is calculated as the difference between the net replacement rate of low earners and the net replacement rate of high earners. Post-reform replacement rates are computed using the OECD pension model and refer to workers entering the labour market in 2006. The calculations are based on national parameters and rules applying in 2006. They fully include the effects of pension reforms already legislated and which will be phased in over time. Pre-reform replacement rates are calculated using pre-2006 reform rules and refer to a worker entering the labour market in 2006. Net replacement rates are calculated as the ratio between net pension entitlements and net pre-retirement earnings taking into account income taxes and social security contributions paid by income earners and pensioners. High (low) income earners are defined as having earnings $50 \%$ above (below) the national average.

Source: Whitehouse, E., A. D'Addio, R. Chomik and A. Reilly (2009), "Two Decades of Pension Reform: What has been Achieved and What Remains to be Done?", The Geneva Papers, 34, The International Association for the Study of Insurance Economics. 
Figure A2.3. Tax systems affect the progressivity of pensions ${ }^{1}$

Difference between the progressivity of gross and net replacement rates, 2008

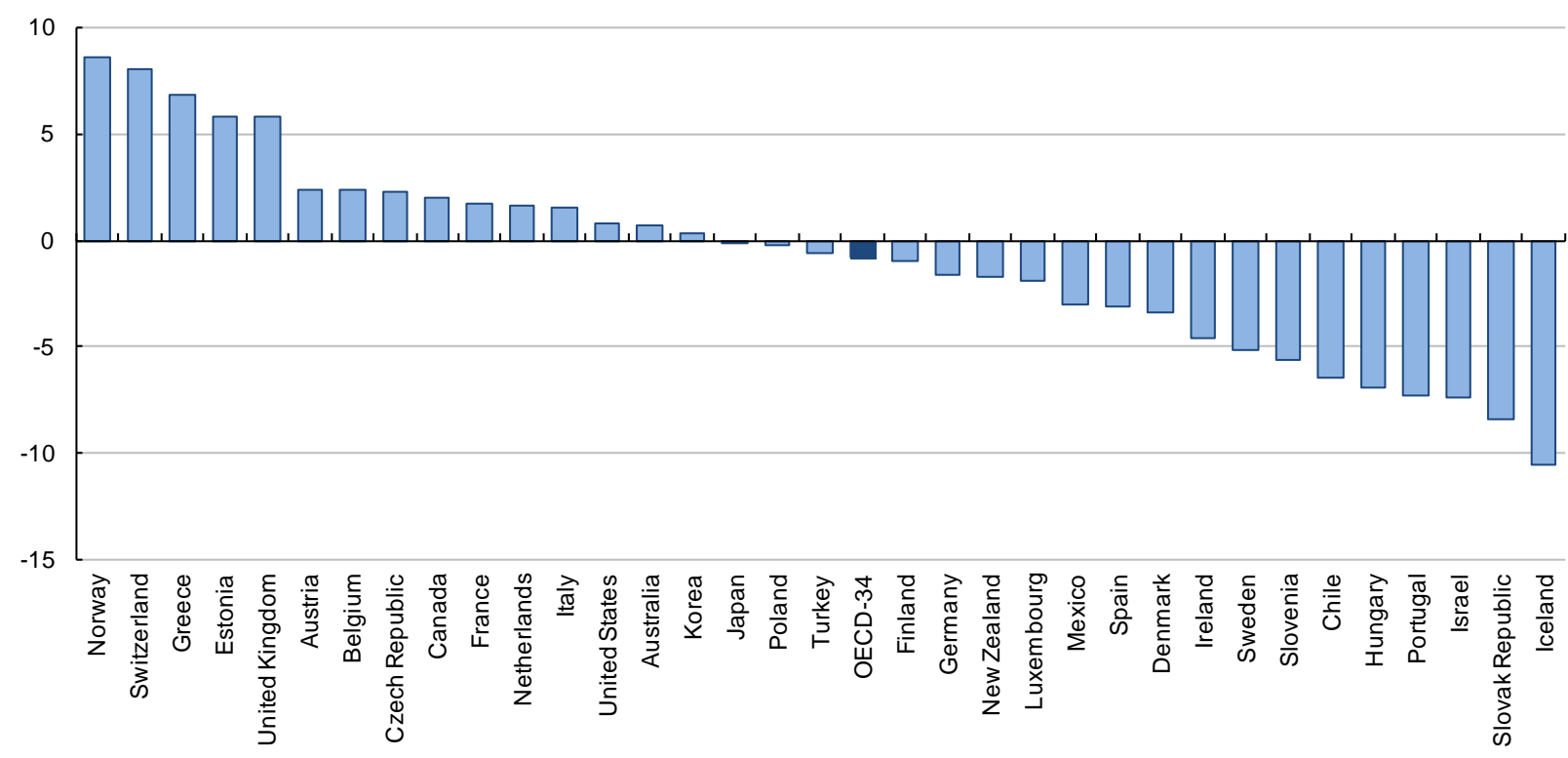

1. The bars show the change in pension progressivity resulting from the tax system. Replacement rates are computed using the OECD pension models and refer to workers entering the labour market in 2008. The calculations are based on national parameters and rules applying in 2008 and include the effects of pension reforms already legislated and that will be phased in over time. The gross replacement rate is computed as the ratio between gross pension entitlements and the average of life-time gross pre-retirement earnings (revalued in line with economy-wide earnings). The net replacement rate is calculated as the ratio between net pension entitlements and net pre-retirement earnings taking into account income taxes and social security contributions paid by income earners and pensioners. High (low) income earners are defined as having earnings $50 \%$ above (below) the national average.

Source: OECD (2011), Pensions at a Glance 2011. 
ECO/WKP(2012)3

Annex 3

Tax and transfer policies - individual country profiles 


\section{Australia Figure A3.1. Tax and transfer policy indicators}

\section{Austria}
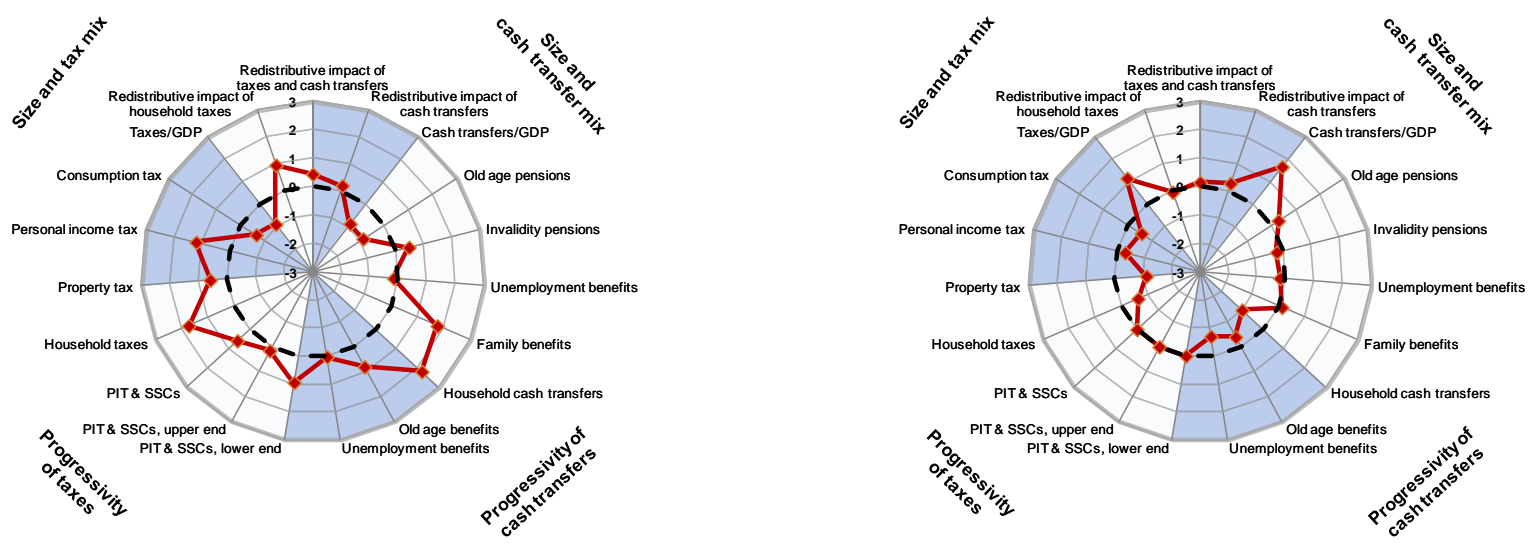

Belgium

\section{Canada}
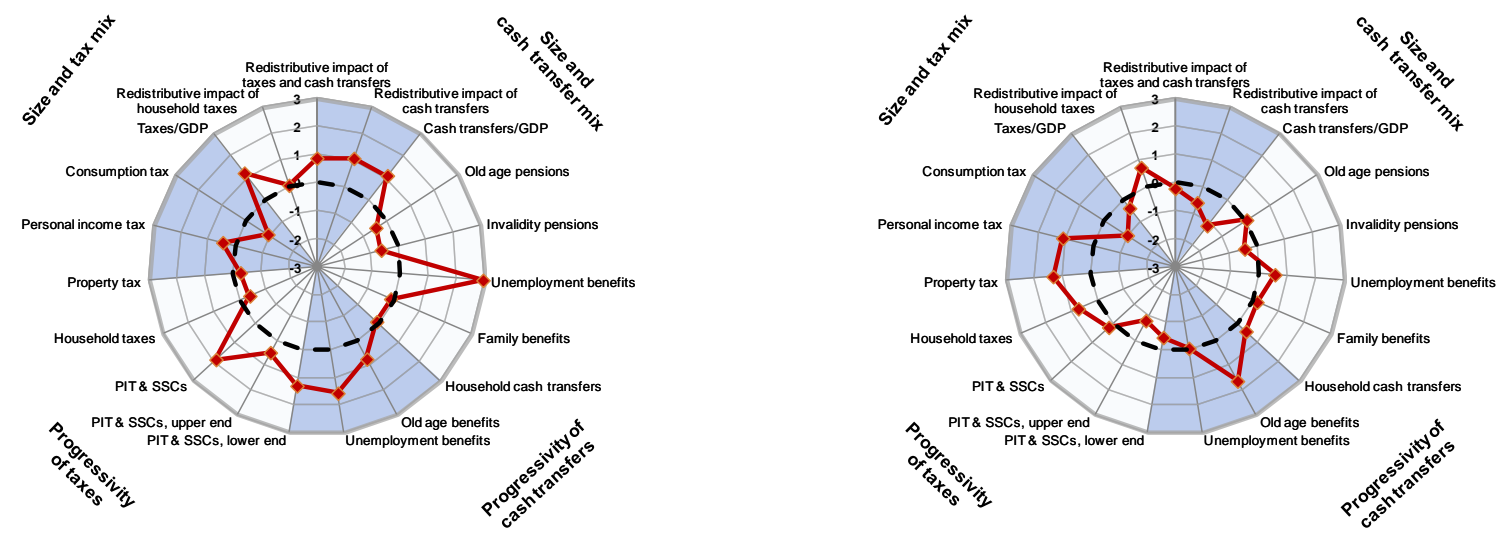

Chile

\section{Czech Republic}
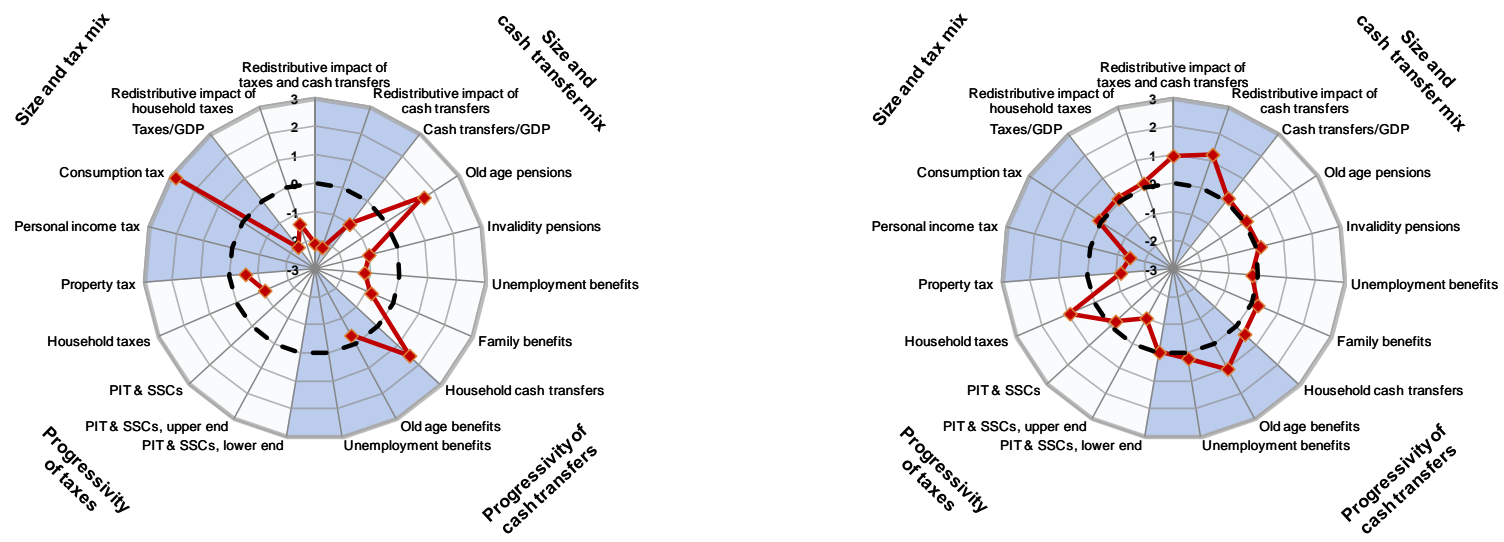
Figure A3.1. Tax and transfer policy indicators, continued

Denmark

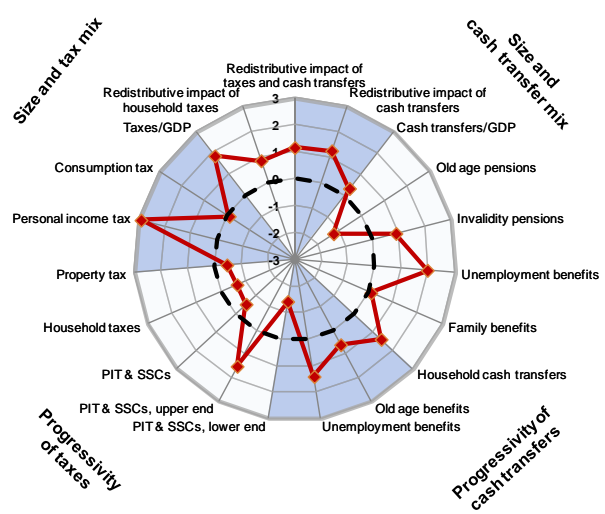

Finland

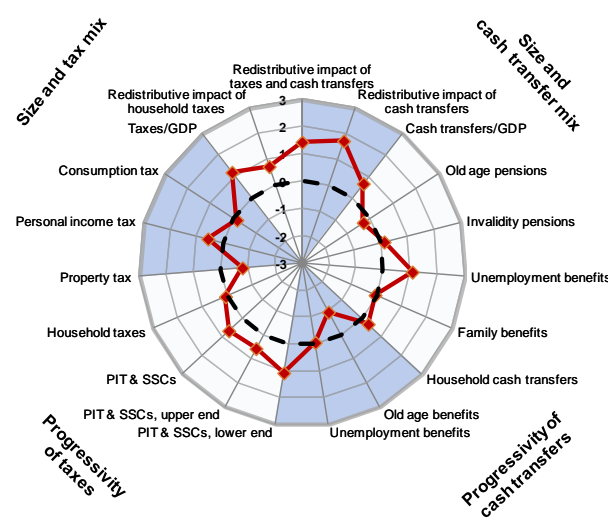

Germany

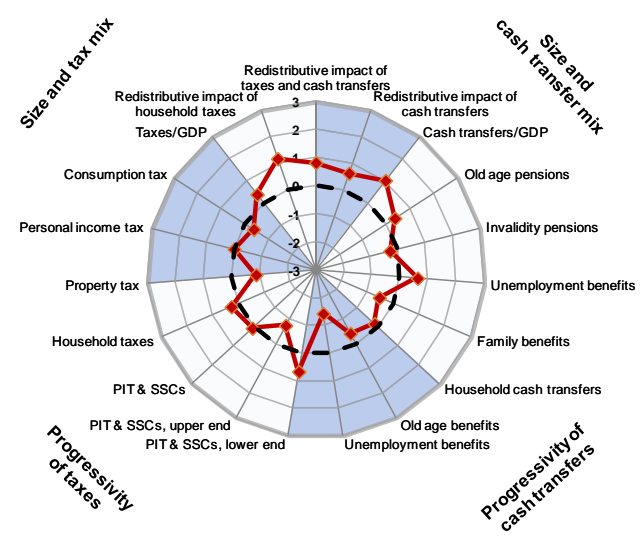

Estonia

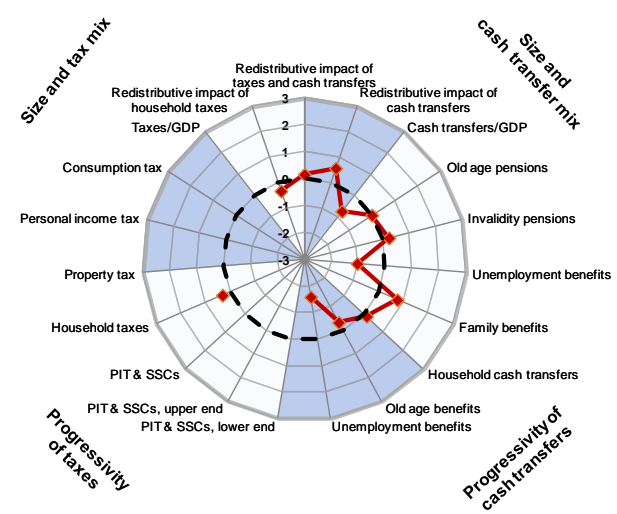

France

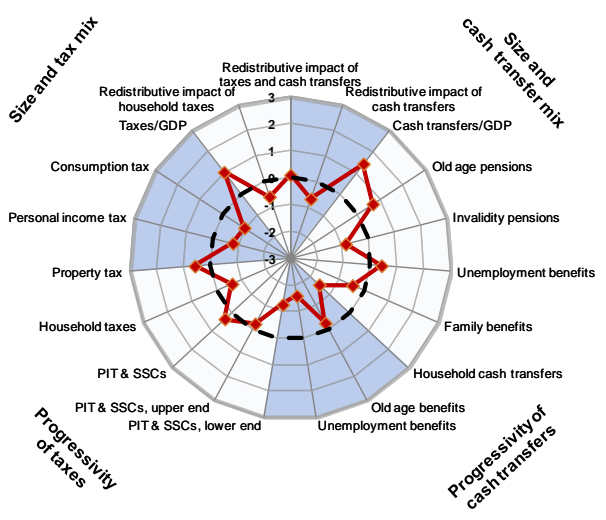

Greece

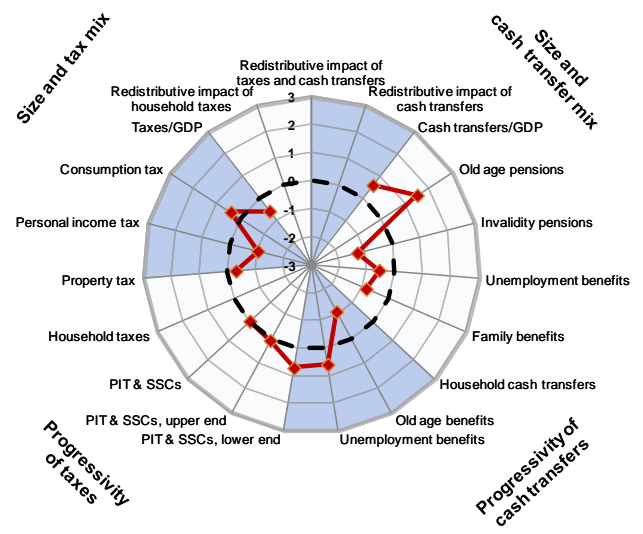


Figure A3.1. Tax and transfer policy indicators, continued

Hungary

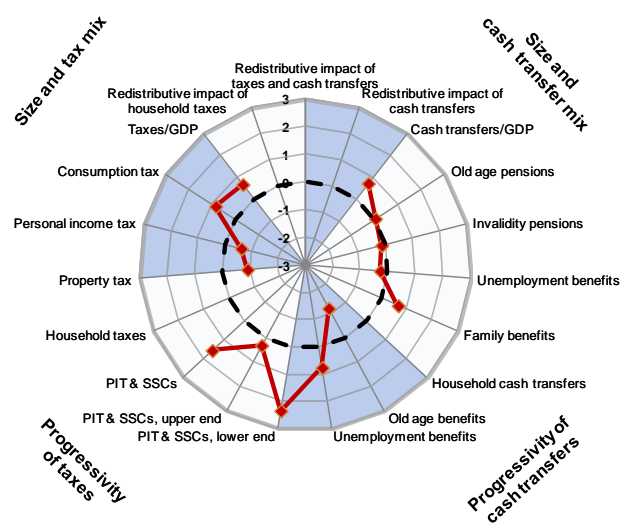

Ireland

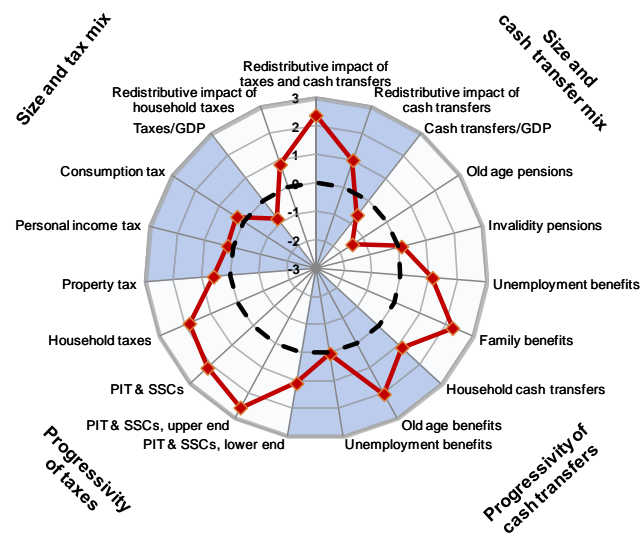

Italy

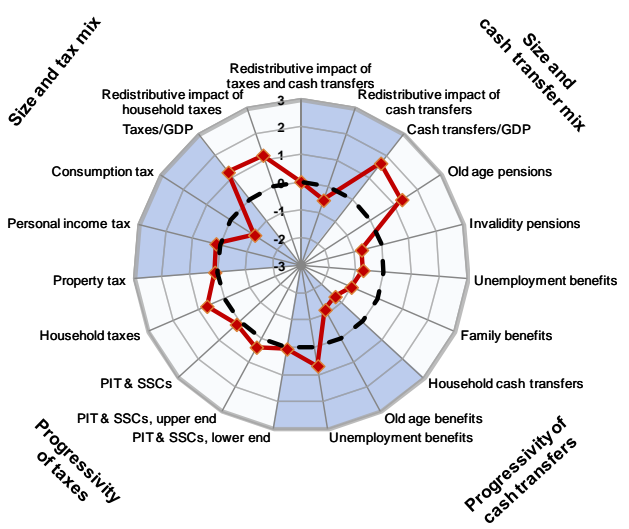

Iceland

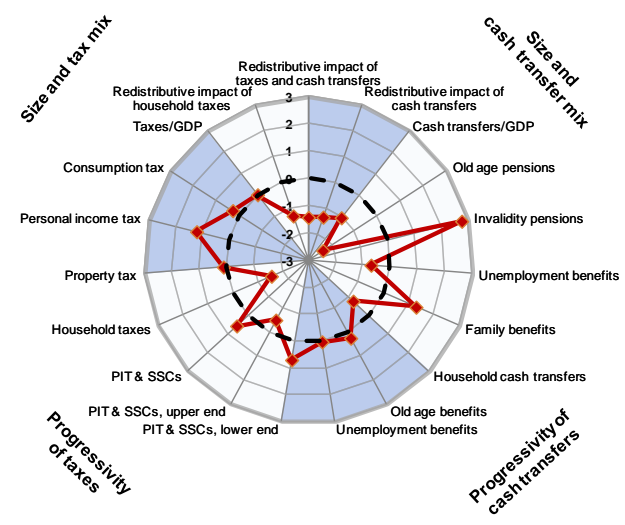

Israel

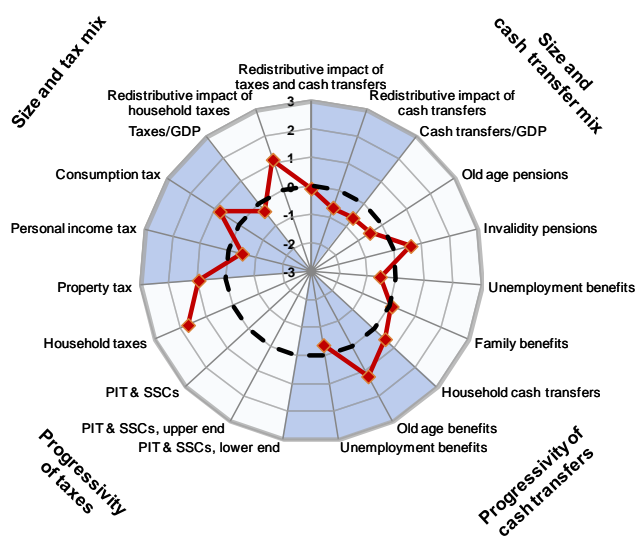

Japan

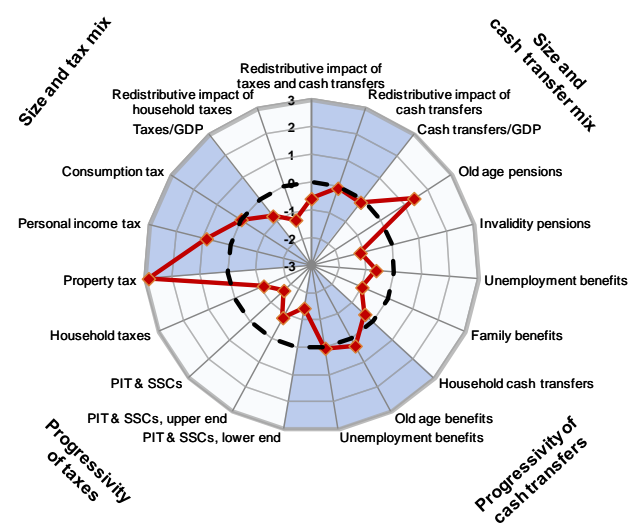


Figure A3.1. Tax and transfer policy indicators, continued

Korea

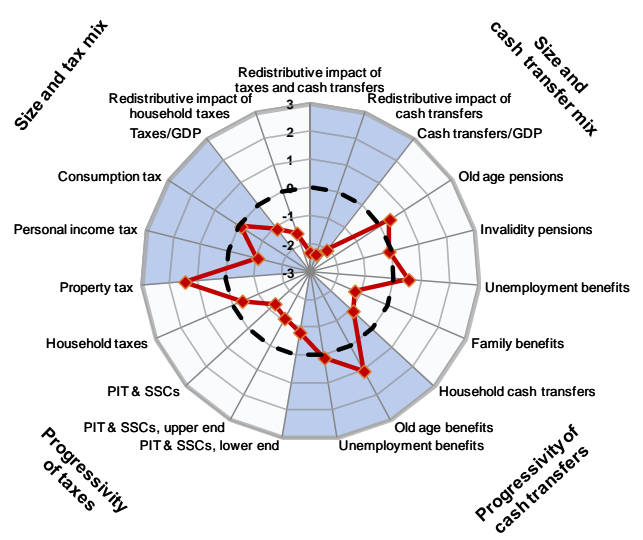

Mexico

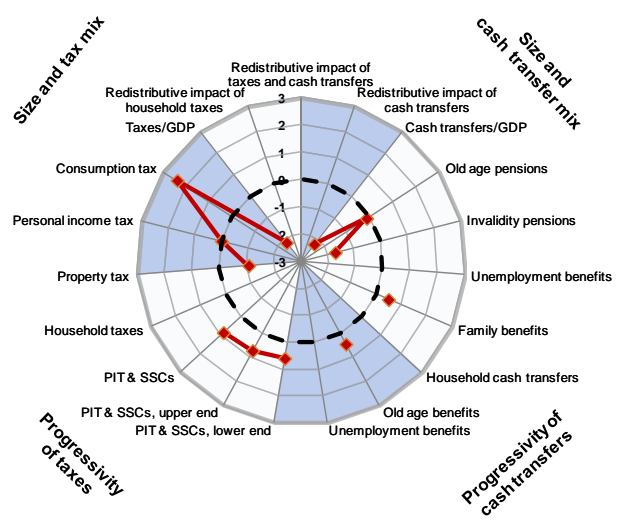

New Zealand

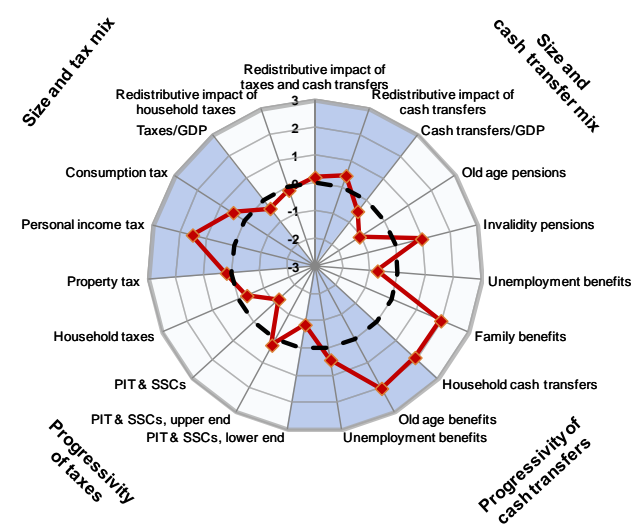

Luxembourg

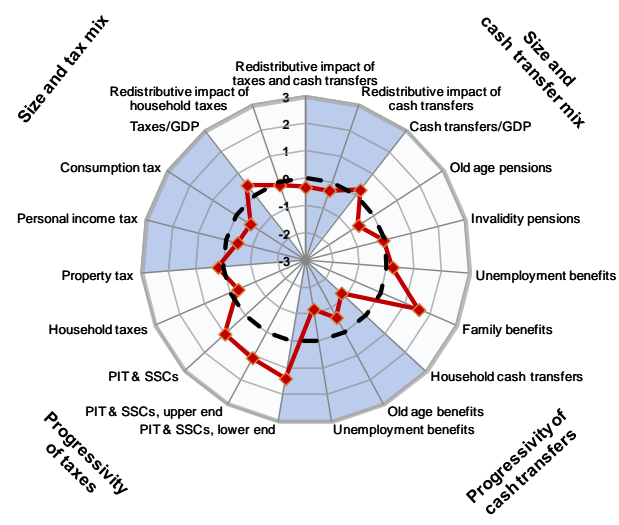

Netherlands

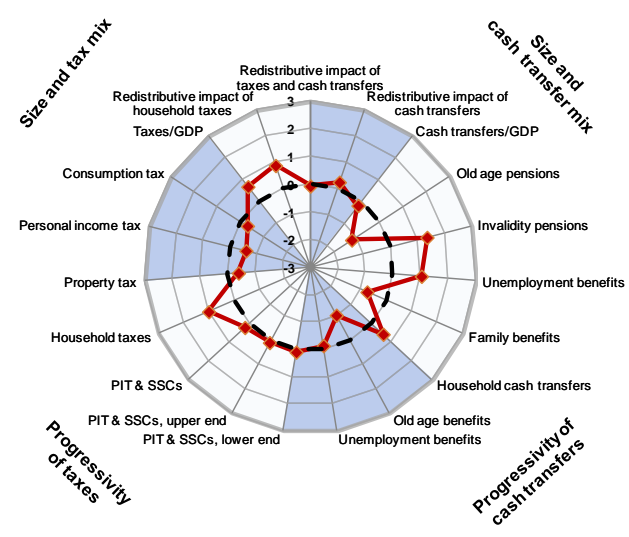

Norway

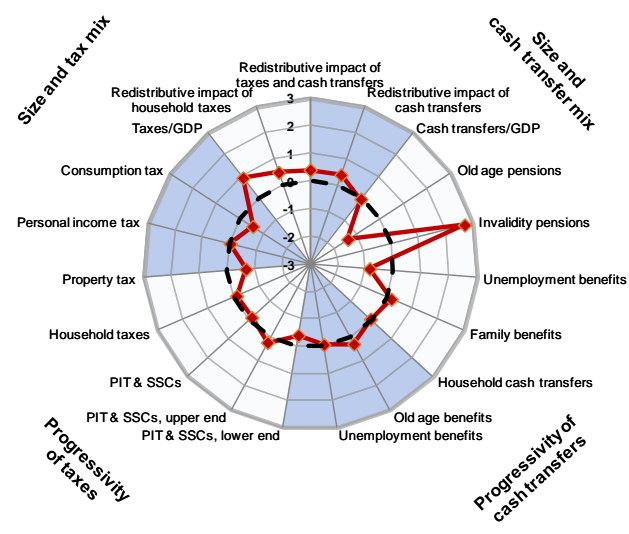


Figure A3.1. Tax and transfer policy indicators, continued

Poland

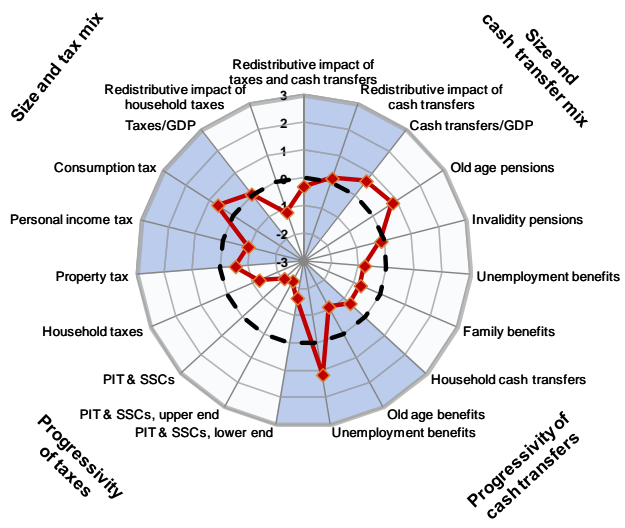

Slovak Republic

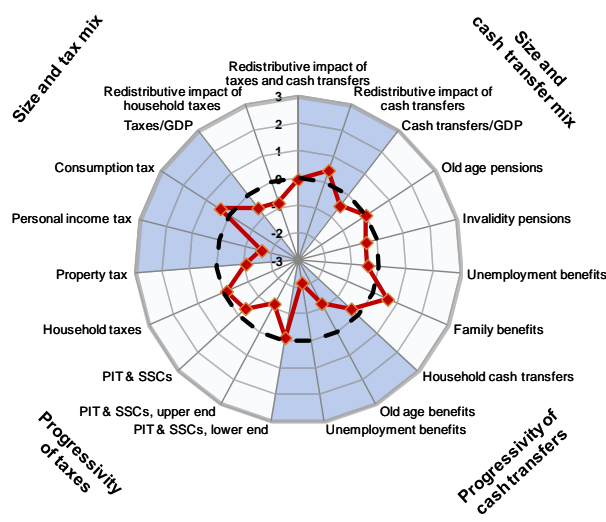

Spain

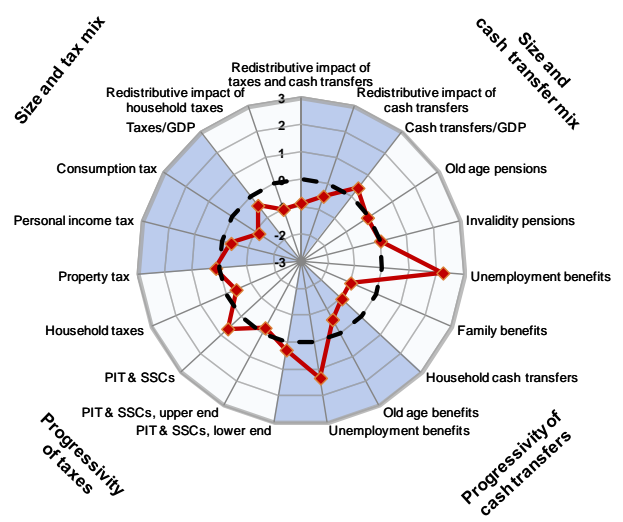

Portugal

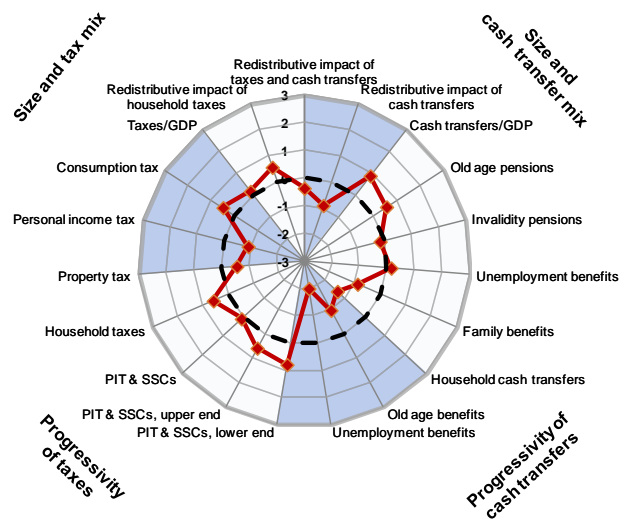

Slovenia

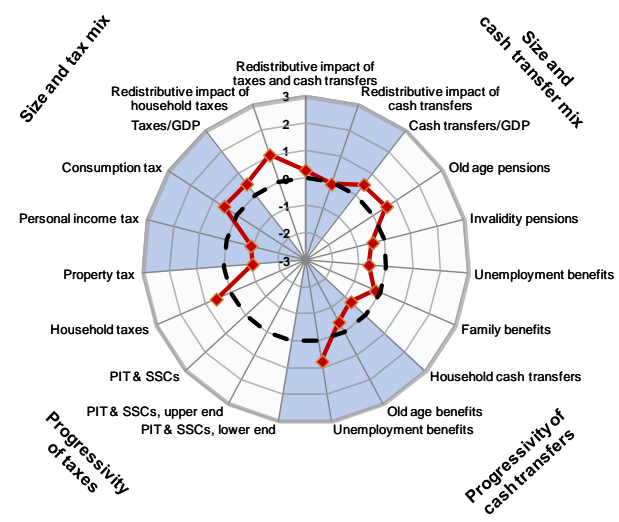

Sweden

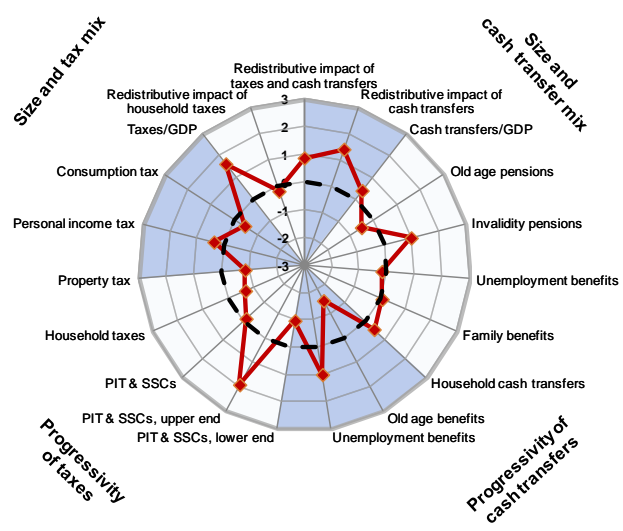


Figure A3.1. Tax and transfer policy indicators, continued

Switzerland

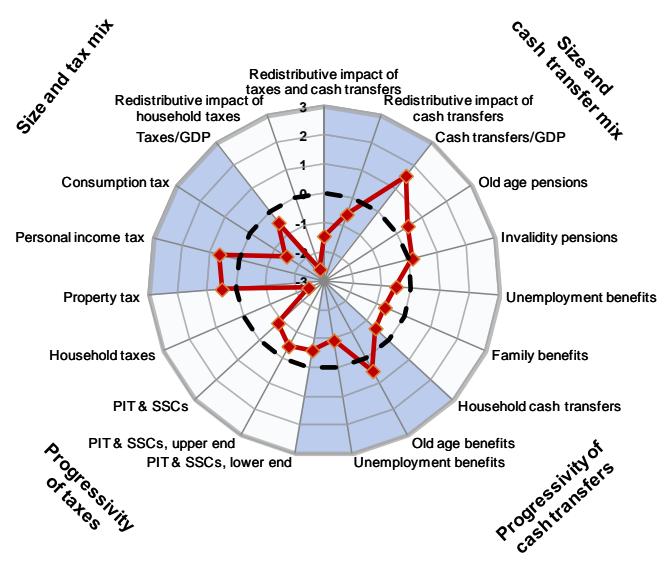

United Kingdom

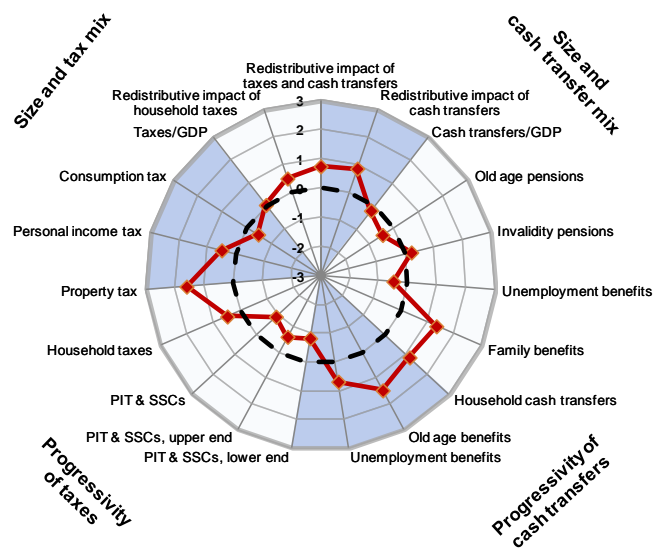

Turkey

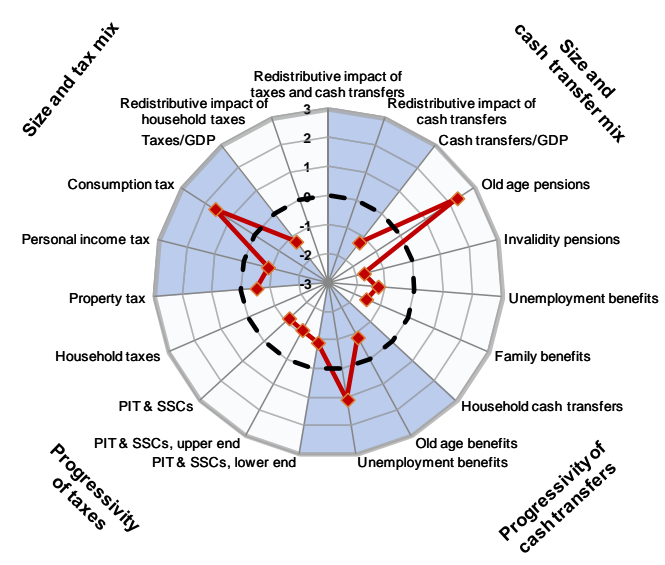

United States

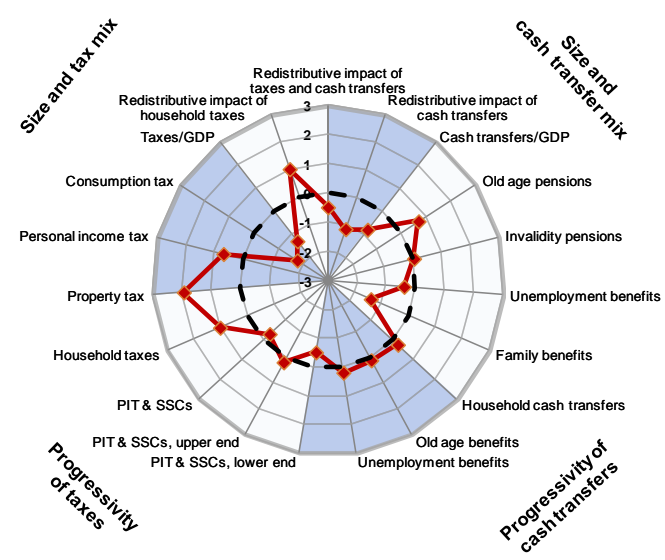

Note: The dotted line represents the OECD average, the solid line represents the country shown. Where the solid line falls inside the OECD average, the variable considered stands below the OECD average. For instance, the tax/GDP ratio in Australia is lower than in the OECD area. Inversely, where the solid line is outside the OECD average, the variable is above the OECD average (the cash transfer/GDP ratio in Germany is higher than the OECD average, for example). The indicators are presented in units of standard deviation.

Legend:

Size and mix of taxes

Taxes/GDP $=$ Total tax revenue, $\%$ of GDP

Consumption tax $=$ Taxes on goods and services, $\%$ total tax revenue Personal income tax $=$ Income taxes on individuals, \% total tax revenue Property tax $=$ Taxes on property, $\%$ total tax revenue

Progressivity of taxes

Household taxes $=$ Progressivity of total household taxe

PIT \& SSCs = Net personal tax progressivity, synthetic indicator, based on income tax plus employee contributions less cash benefits as a \% of gross wage earning, single person without children

PIT \& SSCs, upper end = As above, gap in tax rate between those earning $167 \%$ of the average wage and those at the average wage.

PIT \& SSCs, lower end = As above, gap in tax rate between those earning the average wage and those at $67 \%$ of the average wage

\author{
Size and mix of cash transfers \\ Cash transfers/GDP=Total cash transfers, public and mandatory private sources, \\ $\%$ of GDP \\ Old age pensions = Old age + survivors pensions, \% total cash transfers \\ Invalidity pensions = Incapacity related cash transfers, \% total cash transfers \\ Unemployment benefits = Unemployment cash benefits, \% total cash transfers \\ Family benefits = Family cash benefits, $\%$ total cash transfers \\ Progressivity of cash transfers \\ Household cash transfers = Progressivity of total household cash transfers, \\ total population \\ Old age benefits $=$ Progressivity of pensions and entitlement earnings \\ Unemployment benefits $=$ Progressivity of unemployment benefits, net of taxes \\ for a single person
}




\section{WORKING PAPERS}

The full series of Economics Department Working Papers can be consulted at www.oecd.org/eco/workingpapers/

925. Less income inequality and more growth - Are they compatible?

Part 2. The distribution of labour income

(January 2012) by Isabell Koske, Jean-Marc Fournier and Isabelle Wanner

924. Less income inequality and more growth-Are they compatible?

Part 1. Mapping income inequality across the OECD

(January 2012) by Peter Hoeller, Isabelle Joumard, Mauro Pisu and Debbie Bloch

923. Current issues in managing government debt and assets

(December 2011) by Eckhard Wurzel and Lukasz Rawdanowicz

922. Public spending efficiency in the Czech Republic: fiscal policy framework and the main spending areas of pensions and healthcare

(December 2011) by Zuzana Smidova

921. Exploring determinants of subjective wellbeing in OECD countries - evidence from the World Value Survey

(December 2011) by Sarah Fleche, Conal Smith and Piritta Sorsa

920. Russia: progress in structural reform and framework conditions

(December 2011) by Yana Vaziakova, Geoff Barnard and Tatiana Lysenko

919. Explaining the interest-rate-growth differential underlying government debt dynamics

(December 2011) by David Turner and Francesca Spinelli

918. Reassessing the NAIRUs after the crisis

(December 2011) by Stéphanie Guichard and Elena Rusticelli

917. Employment protection legislation and plant-level productivity in India

(December 2011) by Sean Dougherty, Verónica Frisancho Robles and Kala Krishna

916. Systemically important banks and capital regulation challenge

(December 2011) by Patrick Slovik

915. Improving educational outcomes in Slovenia

(December 2011) by Mehmet Eris

914. Addressing challenges in the energy sector in Israel

(December 2011) by Philip Hemmings

913. Issues in private sector finance in Israel

(December 2011) by Philip Hemmings

912. How to improve the economic policy framework for the housing market in Israel

(December 2011) by Philip Hemmings 
911. Fiscal prospects and reforms in India

(December 2011) by Richard Herd, Sam Hill and Vincent Koen

910. Structural reforms to reduce unemployment and restore competitiveness in Ireland (December 2011) by Álvaro Pina

909. Getting back on track: restoring fiscal sustainability in Ireland (December 2011) by David Haugh

908. A welfare analysis of climate change mitigation policies

(November 2011) by Alain de Serres and Fabrice Murtin

907. Overcoming the banking crisis in Ireland

(November 2011) by Muge Adalet McGowan

906. Macroeconomic and structural policies to further stabilise the Mexican economy

(November 2011) by Cyrille Schwellnus

905. Reaping the benefits of a transition to greener growth in Slovakia

(November 2011) by Caroline Klein

904. Fiscal reform for a stronger fairer and cleaner Mexican economy

(October 2011) by Nicola Brandt and Rodrigo Paillacar

903. The demand for safe assets in emerging economies and global unbalances: new empirical evidence (October 2011) by Rudiger Ahrend and Cyrille Schwellnus

902. Drivers of systemic banking crises: the role of bank-balance-sheet contagion and financial account structure

(October 2011) by Rudiger Ahrend and Antoine Goujard

901. Explaining the appreciation of the Brazilian Real

(October 2011) by Annabelle Mourougane

900. Raising investment in Brazil

(October 2011) by Jens Arnold

899. Refining macroeconomic policies to sustain growth in Brazil

(October 2011) by Annabelle Mourougane

898. Promoting infrastructure development in Brazil

(October 2011) by Annabelle Mourougane and Mauro Pisu

897. Austria: public sector inefficiencies have become less affordable

(October 2011) by Karin Fischer, Rauf Gönenç and Robert Price

896. Informality in Mexico

(September 2011) by Nicola Brandt

895. Reforming Austria's highly regarded but costly health system

(September 2011) by Rauf Gönenç, Maria. M. Hofmarcher, Andreas Wörgötter 